\title{
WestVirginiaUniversity
}

THE RESEARCH REPOSITORY @ WVU

Graduate Theses, Dissertations, and Problem Reports

2017

\section{Representation and Policy Making: Women Participating in the U.S. House}

Lauren M. Santoro

Follow this and additional works at: https://researchrepository.wvu.edu/etd

\section{Recommended Citation}

Santoro, Lauren M., "Representation and Policy Making: Women Participating in the U.S. House" (2017). Graduate Theses, Dissertations, and Problem Reports. 6566.

https://researchrepository.wvu.edu/etd/6566

This Dissertation is protected by copyright and/or related rights. It has been brought to you by the The Research Repository @ WVU with permission from the rights-holder(s). You are free to use this Dissertation in any way that is permitted by the copyright and related rights legislation that applies to your use. For other uses you must obtain permission from the rights-holder(s) directly, unless additional rights are indicated by a Creative Commons license in the record and/ or on the work itself. This Dissertation has been accepted for inclusion in WVU Graduate Theses, Dissertations, and Problem Reports collection by an authorized administrator of The Research Repository @ WVU.

For more information, please contact researchrepository@mail.wvu.edu. 


\title{
Representation and Policy Making: Women Participating in the U.S. House
}

\author{
Lauren M. Santoro \\ Dissertation submitted \\ to the Eberly College of Arts and Sciences \\ at West Virginia University \\ in partial fulfillment of the requirements for the degree of \\ Doctor of Philosophy in \\ Political Science \\ Jason A. MacDonald, Ph.D., Chair \\ Erin C. Cassese, Ph.D. \\ Jeffrey S. Worsham, Ph.D. \\ Shauna F. Fisher, Ph.D. \\ JoNell Strough, Ph.D.
}

John D. Rockefeller IV School of Policy and Politics

Department of Political Science

Morgantown, West Virginia

2017

Keywords: legislative politics; institutional behavior; Congress; gender; representation

Copyright 2017 Lauren M. Santoro 


\section{ABSTRACT \\ Representation and Policymaking: Women Participating in the U.S. House}

\section{Lauren M. Santoro}

Past research has established the link between descriptive and substantive representation (Swers 2002a) and has overwhelmingly focused on agenda setting behaviors and roll call voting (e.g., Swain 1993; Thomas 1994; Swers 2013). The first part of this dissertation focuses instead on deliberations within committee hearings, quite proximate to the law-making process, where legislators exhibit representational behavior. Do women participate in committee proceedings more so than men when they consciously seek to represent so-called "women's interests"? This chapter aims to explore this question by gathering data on House hearings considering the Family and Medical Leave Act and a bill considering the advancement of women in STEM fields. The second part of this dissertation examines how female members of Congress conduct oversight on women's issues. Does the number of women serving on a committee affect the amount of oversight hearings conducted pertaining to women's issues? If so, then electing women makes a clear difference in House deliberations and oversight. Finally, the purpose of the third part of the dissertation is to tease out whether gender acts as an independent "fundamental characteristic" (Swers 2013) or if it is conditioned by district characteristics specifically related to the female reelection constituency. Perhaps congresswomen who are elected from certain districts with particular female reelection constituencies are more apt to introduce bills related to women's issues than are congresswomen and congressmen from other districts. However, I expect that voters' perceptions of congresswomen allow congresswomen to work on public policies related directly to women's needs and repay them with supportive votes, more so than congressmen. If this dissertation as a whole shows that the gender of a member significantly contributes to their behavior, then I have bolstered the literature that connects descriptive representation with substantive representation. 
To Anthony 
Acknowledgements:

Without the help and support of many people, this dissertation would not be possible. First, I would like to thank all of the faculty and staff in the Department of Political Science at West Virginia University. Without their knowledge, kindness, and encouragement, my graduate school experience would not have been the same. I loved my time there and I will be forever grateful to have been a part of such a great department.

I would also like to thank all of my graduate student colleagues. Working on papers together in class, commenting on each other's work before conferences, and being each other's friends and cheerleaders throughout our doctoral coursework was a wonderful experience. I especially want to thank Brian Fitzpatrick and Franchesca Nestor for agreeing to participate in a writing support group with me. I know talking with you made a huge difference for me, in both feeling motivated to write and feeling supported, as well as being validated when I felt overwhelmed. I hope you both think it was worth it and I'm looking forward to seeing you both complete your dissertations later this year.

Out of all my student colleagues, the one I met on my very first trip to campus for orientation became my best friend. Gillian Beach, when I set off on this journey, I never dreamed that I would meet such a kind-hearted and beautiful soul like you. Thanks for being there for me through everything graduate school, Morgantown, and life threw at me. Thanks to Joe, too, for all of the car trips and outings, especially when I broke my arm!

I want to give a whole-hearted thanks to Erin Cassese for being a mentor to me, for being tough on me, and for always being honest with me. I know I learned much more than others did from being a research assistant, so thank you for the work you assigned me and for giving me room to grow and ask questions in the process. Thank you to my other wonderful mentor, Jason MacDonald. Your encouragement, support, and compliments have meant the world to me. I am beyond grateful for all of the help you have extended to me during my entire graduate school career, especially through the dissertation stage. You have been an amazing chair from beginning to end.

And last, but certainly not least, thank you to my family and Pearl. I love you all so much. Anthony, thanks for being the best partner. We are a great team and I could never have made it through this program without your love and support. This dissertation is dedicated to you. 


\section{Table of Contents}

Chapter 1: Do Congresswomen have an impact on policy concerning women's issues?... 1

Chapter 2: Participation of Members of Congress in Committee Hearings Considering Women's Issues... 22

Chapter 3: How the Women of Congress Handle Oversight of Women's Issues...58

Chapter 4: Substantive Representation Revisited: The Relationship of Gender to District Characteristics...74

Chapter 5: Conclusion: Are the women of Congress making a difference in the dynamics of the institution?...99

Bibliography...124

Appendix...134 


\section{Chapter 1: \\ Do Congresswomen have an impact on policy concerning women's issues?}

Academics, commentators, and private citizens who are concerned with gender equality are concerned that gender disparities continue in government. We have yet to see a woman elected president and the percentage of women serving in Congress is 19.4\% (CAWP) out of 535 seats. Figure 1.1 displays the number of women serving in the House and Senate over time by party identification. More women are elected from the Democratic party than from the Republican party, so not only are women as a whole underrepresented, but partisan differences contribute to a stronger underrepresentation of conservative women. There is an outcry to fix such gender inequality, but why do we assume that electing more women will make a positive difference? Perhaps due to the historical marginalization of women, or maybe just because we tend to think that equality means fairness, we assume that electing more women to Congress would be good for the country. In Congress, the implication is that more women would be a good thing for representation and public policy. People also tend to assume that descriptive representation (being a woman) and substantive representation (being a proponent of women's interests) are connected (e.g., Mansbridge 1999; Phillips 1995; Pitkin 1967; Sapiro 1981). This means that beyond women simply making a difference because they are elected to an institution that is majority male, women will also better represent women than their male counterparts.

Does descriptive representation enhance substantive representation? In political science scholarship, we have much evidence to support that it does. Not only do women actively seek to represent the needs of female citizens (Carroll 2002; Reingold 1992, 2000; Rosenthal 1998; Thomas 1994, 1997), but women in both the House and Senate support women's issue legislation through bill sponsorship, co-sponsorship, and roll call voting (e.g., Swers 2002a \& 2013). Similarly, female representatives at the state level also prioritize women's issues (e.g., Berkman 
and O'Connor 1993; Dodson and Carroll 1991; Dolan and Ford 1995; Saint-Germain 1989; Thomas 1994). From this briefest of overviews, it is clear that in order to represent the needs of women in America more women have to be elected to all forms of public office, including state legislatures and Congress.

This dissertation focuses on exploring, and thus adding to knowledge on, the link between descriptive and substantive representation. Each chapter focuses on a different question about women's actions in Congress. But the overarching question to the dissertation is: does electing women to Congress make a difference in the actions that occur on the policies specifically related to women's issues? I investigate behaviors that are proximate to the policymaking process in order to appropriately determine whether congresswomen behave differently than their male colleagues. If this dissertation shows that the gender of an individual legislator can significantly predict their behavior, specifically how they participate in Congress, then I can bolster the link between descriptive and substantive representation. In the remaining portion of this literature review chapter, I will discuss both the current state of the gender and politics literature, as well as the literature on both Congress and women participating in government that has brought me to the research questions of each empirical chapter.

\section{Women Participating in American Government}

What motivates members of Congress to act? Can we answer that question without considering the personal characteristics of the member? Of course, we can make generalizations about members of Congress, and those generalizations are helpful, but when we start contemplating how the actions of members of Congress affect their constituents due to their primary role as representatives, we must consider all factors that may affect their motivations, including their gender. Previous research has concluded that members of Congress are largely 
motivated by reelection (Mayhew 1974) and the interest in creating good public policy (Arnold 1990; Fenno 1973; Hall 1996). By adding concerns about the role personal characteristics like gender play to such findings, I ask: do the men and women of Congress differ when they participate because of differences in motivation, such as how they view reelection and making good policy because of their gendered identity?

The literature investigating the role of women in government has considered these questions of motivation, and has done so by looking at women serving in Congress and women serving in state legislatures. First, women serving in both state legislatures and Congress feel a responsibility to specifically represent women. They think of women as a distinct constituency and express commitment to representing women, whether in their district or not (Carroll 2002; Dodson et al. 1995; Foerstel and Foerstel 1996; Gertzog 1995). For example, Senator Barbara Boxer (DCA) described how she felt:

There are still so few women in Congress... So you really do have to represent much more than your own state although my state is huge... Women all over the country really do follow what you do and rely on you to speak out for them on the issues of women's health care, reproductive choice, conditions of families, domestic priorities, environment...equal pay for equal work...I even had that in the House of Representatives, which was incredible because I just came from a small district. So, it is a pretty big burden. And I remember when I came [to the Senate], Barbara Mikulski said, "Oh, my god, thank god, someone I can share this with," because she carried the load for so long as the only Democratic woman in the Senate. ${ }^{1}$

No matter the party ideology, race, ethnicity, tenure in office, or institutional position, women speak similarly of the responsibility to represent American women (Carroll 2002). Findings such as these are very important for two reasons. First, it helps cement the link between substantive and descriptive representation. This means that when we elect women to state

\footnotetext{
${ }^{1}$ Quoted from Carroll 2002.
} 
legislatures and Congress, women actively seek to represent the needs of women in their districts, as well as women in general ${ }^{2}$. In other words, electing a female representative (descriptive) leads to policies that favor women (substantive). Second, because female representatives act to best represent the needs of women in the electorate, we can assume that female representatives not only seek to make good public policy for women, but also seek the votes of women. In fact, women in state legislatures are more likely than men to view women as a distinct part of their constituencies (Reingold 1992; Thomas 1994, 1997). We can even say that this propensity to consciously represent women is a part of a Congresswoman's home style (Fenno 1978).

We see the above-mentioned findings further exemplified in agenda setting behavior, such as roll call voting ${ }^{3}$. In Congress, women sponsor and cosponsor more feminist bills ${ }^{4}$ and bills related to women's traditional role as caregiver ${ }^{5}$ than men (Swers 2000, 2002; Tamerius 1995; Vega and Firestone 1995; Wolbrecht 2002). At the state level, female representatives prioritize women's issues, too. They pursue feminist initiatives and legislation, as well as legislation concerning issues of traditional importance to women, such as education, health, and welfare (Berkman and O'Connor 1993; Dodson and Carroll 1991; Dolan and Ford 1995; Saint-Germain 1989; Thomas 1994). Importantly, women also seem to be more effective than their male colleagues. At the state level, female representatives are more likely to see their legislation that

\footnotetext{
${ }^{2}$ Both symbolic and surrogate representation are terms sometimes used to describe such a scenario, where the member of Congress feels the need to represent people who live outside of their district, but who share important personal characteristics with them, such as race, ethnicity, sexuality, or gender (Mansbridge 2003).

3 Agenda setting behavior indicates a legislator's interest in legislation more so than position taking behavior because agenda setting takes up valuable resources, such as time spent researching and preparing a bill to introduce. Sponsorship and co-sponsorship also indicate the legislator's interest in arguing to pass the bill, again indicating their willingness to spend time doing things like testifying for the bill in committee hearings or persuading other legislators to vote for the bill.

${ }^{4}$ Examples: reproductive rights, protecting victims of domestic violence, increasing funding for women's health research, establishing gender equality programs in education, etc.

${ }^{5}$ Examples: health care, education, poverty assistance
} 
advances women's interest passed into law compared to men ${ }^{6}$ (Saint-Germain 1989; Thomas 1994).

Gender also seems to make a difference in position-taking behaviors, such as roll call voting and floor debate. When considering ideology, women in state legislatures tend to hold more liberal policy attitudes than men. In Congress, however, there have been mixed findings about whether women are more liberal than their male counterparts (Burrell 1994; Frankovic 1977; Gehlen 1977; Leader 1977; McCarty, Poole, and Rosenthal 1997; Welch 1985). Since we cannot say with certainty that there is one generalizable finding about women's ideology, I think we need to consider both gender and ideology carefully in terms of participation in government, noting when one is a stronger indicator of behavior than the other, and when they both seem to matter. While ideology can be likened to a lens through which humans view the world, gender is a defining characteristic that influences all social interactions (Lorber 1994). Therefore, it is important to further explore how these two factors motivate members of Congress. For example, when the policy directly concerns gender, like abortion (Tatolovich and Schier 1993) or a set of women's issues (Burrell 1994; Dolan 1997; Swers 1998), female representatives tend to vote similarly, somewhat disregarding ideology and partisanship.

Furthermore, during floor debates, women exhibit a higher rate of participation than their male counterparts on women's issues (Cramer Walsh 2002; Swers 2000; Tamerius 1995), as well as speaking with a distinctive voice on such issues (Cramer Walsh 2002; Dodson et al. 1995; Levy, Tien, and Aved 2001; Swers 2000). For example, Levy, Tien, and Aved (2001) show that women have been successful in reframing the debate on abortion in terms of women's health, moving the

\footnotetext{
${ }^{6}$ There are also interesting findings at the national level that show that minority party women in the House are more effective (getting a sponsored bill through the stages of the legislative life cycle), in general, than majority party women and all male colleagues (Volden, Wiseman, and Wittmer 2013).
} 
discussion of the Hyde Amendment ${ }^{7}$ away from a simple morality debate. When women frame debates similarly to their male counterparts, they tend to speak on behalf of marginalized constituencies more than men, as well as speak to their experiences in ways only women can, thus effectively expanding the debate (Cramer Walsh 2002). Women also tend to have a distinctive way of thinking about policy problems, as Kathlene (1995) shows in her study, which compares the way women and men think about criminals and therefore crime policy, due to their socialized gender differences.

When it comes to actively working on legislation in committees, women participate differently than their male colleagues. At the state level, women in the Colorado legislature entered the committee hearing debates later, spoke less often than their male colleagues did, and interrupted witnesses less frequently than male legislators did (Kathlene 1994). The findings also suggest that as the number of women serving in a legislative body increases, male members become more verbally aggressive and controlling of hearings (Kathlene 1994). This obviously puts women at a disadvantage in their goal of creating good public policy. However, other findings at the state and national level show that female representatives are able to actively advocate for female constituents by fighting to incorporate more women's interests into committee legislation (Dodson 1998, 2002; Dodson et al. 1995; Gertzog 1995; Norton 2002; Swers 2000, 2002). Also, female committee chairs in state legislatures have reported a more integrative leadership style than their male counterparts, by sharing power with others, collaborating with other chairs, and by sharing strategic information with committee members (Rosenthal 1997, 1998, 2000). Plus, women are less likely than men to say they care about achieving powerful positions; rather, they want to move up the ladder, pull people together, build issue coalitions, and develop creative

\footnotetext{
${ }^{7}$ The Hyde Amendment prevents public funds from being used for abortion services.
} 
approaches to solving policy problems (Rosenthal 1997). This means that when we elect women, we get different results---a different type of legislator---than when we elect men. However, we feel about such results, we must also consider the effects that the characteristics of the institution have on legislators.

At the state level, work on critical mass and the presence of a women's caucus explores what we are unable to with data from Congress, since so few women are elected. As women increase their proportion in the legislatures, they are more willing to pursue policy preferences based on gender (e.g., Kanter 1977). Also, differences in the policy priorities of the genders intensified as the proportion of women reached a "critical mass" (Berkman and O'Connor 1993; Saint-Germain 1989; Thomas 1994). As for the presence of a women's caucus, they provide more resources for female representatives, reducing the potential negative effects of tokenism (Thomas 1994 and Saint-Germain 1989).

Furthermore, acknowledging the part that institutional norms (who is in the majority/minority; committee positions; leadership roles) play is important to understanding the role of gender. Dodson $(1995,1998,2002)$ demonstrates how Democratic and Republican women in the 103rd Congress used their positions on key committees and within the party leadership to make certain that legislation concerning violence against women, reproductive rights, and women's health gained a place on the national agenda. Swers (2002) finds that being a member of the majority or minority party affects congresswomen's behavior. When she discusses her main findings ${ }^{8}$, she adds some context as to why female Republicans behaved the way they did. When they were a part of the minority party, they proposed more feminist bills, joining female

\footnotetext{
${ }^{8}$ In terms of roll call voting, male and female Democrats vote similarly, in favor of women's issue bills and female Republicans often join them. Also, when they can introduce bills on anything, moderate Republican women and Democratic women introduce more bills on women's issues and feminist issues than their male colleagues.
} 
Democrats. When they were a part of the majority party, they continued to work on women's issues, but shifted their focus to social issues, avoiding rocking the boat. They wanted to curry favor with their party and prevent being alienated. In a more recent work, Swers (2016a) again finds that congresswomen (this time senators) cannot simply act as women who wish to represent women; rather, women must act in terms of institutions, like the political party they are members of (especially for Republican women), and the position that party holds in the current session of Congress.

Discussing the state of the gender and politics literature has led me to think more about testing the connection between substantive and descriptive representation. Furthermore, can I show that electing women to Congress makes a difference in the actions that occur on the policies specifically related to women's issues? I believe that I can, and in the following section, I will discuss how the literature leads to the various research questions I will answer in the dissertation.

\section{Contribution to the Literature}

The women and politics area of political science literature tends to focus on the connection between descriptive and substantive representation. The area of literature examining this connection and more general gender effects is extensive; however, it has not considered the specific ideas I propose to study. The three substantive chapters of the dissertation, briefly detailed in the following three paragraphs, will focus on the differences in participation and behavior between the men and women of the U.S. House of Representatives. In the sections following this brief discussion, I will expand on the three empirical chapters, noting my contributions to the literature.

Chapter 2 studies how male and female members of Congress differ in their participation levels during committee hearings considering two women's issue bills: The Family and Medical 
Leave Act and the Commission on the Advancement of Women and Minorities in Science, Engineering, and Technology Development Act (hereafter the FMLA and the SET commission). The timeframe for the FMLA hearings spans from 1985 to 1993, and the SET commission from 1992 to $1998^{9}$. This chapter allows me to make a new contribution to the literature by comparing the participation of men and women of the Democratic and Republican parties, showing that men and women participate at different levels. This chapter makes an important contribution to the field by focusing on deliberations within committee hearings, where legislators exhibit representational behavior. Since hearings are proximate to the policymaking process, it is important to investigate the difference women make when they participate in such situations, especially when considering women's issues.

Chapter 3 focuses on oversight. I expect that if more women are members of a committee, then that committee will spend more time on oversight of women's issues than committees with fewer female members. This chapter is a contribution to the field because while oversight is an important legislative activity, it is again (as in the previous chapter) proximate to the policymaking process. Scholars may expect women to act differently than men, but this dissertation chapter will examine the critical yet understudied motivations for this difference of behavior among committees with varying numbers of female members as well as committees conducting oversight of women's issues. Because this has not been done in previous literature, this chapter will contribute to the development of a clearer understanding of how gender affects congressional behavior and electoral representation.

\footnotetext{
${ }^{9}$ The House held nine total hearings on the FMLA: one in 1985, two in 1986, three in 1987, one in 1989, one in 1991, and one in 1993. The House held three total hearings on the SET commission: one each in 1992, 1994, and 1998.
} 
Finally, Chapter 4 will explore how district characteristics might condition how gender influences representation by examining bill introduction activity. I will do this by adding new independent variables specifically related to women within the congressional district. If congresswomen think of women as a specific reelection constituency, then I expect district characteristics specifically related to women may play a role in the type of bills introduced by female members. If partisan legislators are willing to "trespass" on the other party's issue ownership due to voter preferences (Sides 2006), then perhaps if certain kinds of female voters are present in a district, then both female Democrats and female Republicans will strategically introduce women's issue legislation, even though such issues tend to be viewed by voters as "owned" by Democrats. Therefore, the purpose of this chapter is to tease out whether gender acts as an independent "fundamental characteristic" (Swers 2013) or if it is conditioned by district characteristics specifically related to the female reelection constituency.

How does gender affect the participation of members of Congress in committee hearings?

In Chapter 2, I study committee hearings considering women's interest legislation. Reelection (Mayhew 1974; Arnold 1990) and genuine interest (Hall 1996) are the more general and typical explanations given for the motivation of members of Congress. While I do not discount these explanations, I also take into account the importance of gender. As previously mentioned, many authors have contributed to the female representation literature by investigating Congress and the gender differences within parties evidenced by voting behavior. There are mixed results when comparing how liberal women and men tend to be. Vega and Firestone (1995) studied behavior in the form of roll call voting and bill introduction between 1981 and 1992. They wanted to know whether having women in Congress (descriptive representation) affects behavior and 
therefore affects substantive representation. Overall, women had slightly more liberal voting patterns than their male colleagues, and Republican women were statistically significantly more liberal than Republican men in nine of the twelve years examined. However, the gender gap within parties is closing with time. Bill introduction data for the same period reveals that congresswomen are introducing women-related legislation proportionate to their number and not disproportionately more as might be expected. Vega and Firestone conclude that while their results are mixed, there is a potential for women of both parties to continue to vote similarly and therefore increase the connection between descriptive and substantive representation. Such findings are why I expect to see a strong connection between descriptive and substantive representation when examining FMLA and SET commission hearings. I expect women to participate more than men in order to accomplish a policy goal that benefits female constituents.

Michele Swers is also concerned with determining the policy effects women have in Congress (1998). She specifically investigates behavior concerning women's issue votes. Her reasoning is simply that the more an issue directly affects women, the more likely women will vote together, disregarding party. She finds that gender exerts influence over voting behavior on women's issue bills, but ideology is a better predictor. Importantly, a pattern does emerge of Republican women defecting from party and voting for women's issues more than their male Republican colleagues. Also, her evidence refutes the notion that gender differences can be entirely explained by district characteristics. In fact, "districts with higher median household income are more supportive of women's issues" (Swers 1998, 440; see also Palmer and Simon 2006). Women's issues affect all women, across social and class differences. Bills that most affect women's health and reproductive issues drive the gender differences. Ideology, partisanship, and district factors take over when considering the bills that dealt with peripheral issues, like education. 
No matter the party, congresswomen are more willing to vote in favor of bills that directly affect women.

In order to substantiate these important findings, Swers' book (2002) examines five steps in the policy process to fully investigate gender differences within the parties: bill sponsorship, cosponsorship, amendments in committees, defending women's issues on the floor, and roll call voting. All five point to the conclusions drawn in her 1998 article: moderate Republican and most Democratic women are more willing to work for women's issues than men. Her most interesting finding for the purposes here is that the largest gender gap occurs in the sponsorship step of the process. This implies that when women are able to pursue any issue that interests them and their constituents, they choose to introduce legislation related to gender and family, which also what Thomas (1994) finds at the state level.

Although the findings on bill introductions is a strong indicator of the connection between gender and behavior, Chapter 2 seeks to better understand bill construction and the committee process. When considering amendments in committee, Swers (2002) admits her study "does not capture any pre-markup activity in which members work to convince the chair to include their proposals in the chairman's mark, the bill that will be subject to amendment during the markup" (78). My chapter specifically addresses this behavior within committees. Also, as Swers (2002) mentions, members have to engage in persuasive behavior, which indicates their level of interest. The more interested they are in constructing the bill, the more they are going to participate in committee. In Norton's (2002) article, she discusses the findings of Hall who "contends that personal policy interests determine how actively members will participate on an issue once seated on the appropriate committees" (318). I believe my analysis will show that gender predicts 
participation on women's interest legislation because gender can somewhat account for personal interest.

While the extant literature has established a link between descriptive and substantive representation, it has overwhelmingly focused on agenda setting behaviors and roll call voting (e.g., Swain 1993; Thomas 1994; Swers 2002a; 2013). In order to address the question of policy, Volden and Wiseman $(2009 ; 2014)$ show that women are more effective overall at passing legislation through the process than men (based on Legislative Effectiveness Scores). In their 2013 article (with Wittmer), they show that minority party women drive this effect in every stage but bill introductions, where majority party women are more effective. They conclude that because women have consensus building traits, they are able to use those traits when they are in the institutional position of minority. Focusing on legislative effectiveness, roll call voting, and agenda setting behaviors simply does not allow us to assess whether women participate more when it comes to behavior that affects the substance of policy.

While these previous studies of Congress have produced compelling results considering behavior and overall legislative effectiveness, none have examined how gender can contribute to participation of members in committee hearings. In fact, Volden, Wiseman, and Wittmer (2013) find that both minority and majority party women are not able to get bills considered in committee at a statistically significant level, indicating they are no more effective than their male counterparts. I argue that women may be effective in a different way at the committee stage by participating more than their male colleagues. This participation is particularly important because participation in committee hearings can affect the outcome of a bill's content. The content of a bill is directly affected by participation in committee hearings (Hall 1996). This participation is also particularly close to the policymaking stage whereas past analyses showing gender effects are more removed 
from the policymaking stage. Because participation in committee can alter policy, it is highly selective. Members will only spend their time participating when the policy area captures their personal and/or constituency's interest (Hall 1996). Therefore, in order to understand how and why women are important to improving substantive representation of women's interests, we need to understand whether there is a gender effect during legislative participation. Are women choosing to spend their valuable time participating more on women's issues than men? If they are, women have more of a direct impact on the policymaking process than previously thought.

With particular inspiration from Hall (1996) and Swers (2002), Chapter 2 asks: Do women participate more on women's issue bills in order to get these bills passed than their male colleagues? I structure part of my argument around Hall's contention that if a member is interested in a policy, they participate more in committee. "Participation in Congress, for the most part, is not a matter of institutional design or authoritative delegation; for the most part, it is a matter of individual choice (Hall 1996; 5). Similarly, King (1997) shows that in order to gain turf, members spend time in committee hearings cultivating expertise. Members have to make a choice to participate, and that choice is often made via personal interest. I will measure participation through analysis of committee hearings. I also consider traceability's effect on participation by comparing a high-salience and low-salience bill: the FMLA and the SET commission, respectively. The concept of traceability refers to whether an action is particularly salient, or able to be traced back to the member, by their constituents (Arnold 1990). The FMLA was highly salient, so it might be more likely that I observe an effect. Therefore, I also examine SET as a comparison. On a less salient bill, members can feel free to act based on personal beliefs and, to a certain extent, disregard constituent opinion. 
Overall, I predict that women will take more of an interest in passing these bills than their male colleagues and therefore participate more in committee hearings, thus providing greater substantive representation of women's interests. Therefore, my contribution is to examine whether gender improves representation while studying representational behavior that affects policy outcomes-behavior that is closer to the decision point than prior studies of gender and representation. Critically, whereas past research has observed a link between descriptive and substantive representation with respect to bill sponsorship and other behaviors that are peripheral to behavior that determines what the substance of law is, I examine how much work lawmakers do when committees are making choices that determine the language that comprises the law. In this way, I move the literature forward by exploring behavior that is particularly proximate to the policymaking process---behavior that is important for testing the link between descriptive and substantive representation. The next section discusses the literature related to Chapter 3 . It extends theory presented in this chapter about legislative hearings to oversight hearings considering women's issues.

\section{How does gender affect oversight?}

The theory behind Chapter 3 of the dissertation begins by focusing on much of the same literature presented for Chapter 2 above. We know that congresswomen use their committee positions to advocate for the incorporation of women's interests into committee legislation (Dodson 1998, 2002; Dodson et al.1995; Gertzog 1995; Norton 2002; Swers 2002b). Therefore, members of Congress will act according to personal interest (Hall 1996) and gender (e.g., Swers 2002a) when it comes to participating in hearings considering women's issue bills. In this chapter, I focus specifically on oversight hearings. While the total number of days spent on hearings and 
meetings in the House have declined over time, the number of oversight days has increased (Aberbach 2002). Since oversight is such an important activity to the members of the House, and because oversight is an activity where legislators are given the chance to participate in policy change, I investigate whether the number of women on a committee causes that committee to conduct more oversight of women's issues than committees with fewer congresswomen. I predict that the more women on a committee, the more likely that the committee will conduct oversight of women's issues, thus further illustrating the connection between descriptive and substantive representation.

According to Darcy (1996), women have had their "fair share" of access to power through committee chairmanships within state legislatures. This "fair share" of power has not been achieved in the House of Representatives. For this reason, it is important to examine what female chairs do when they are able to have power over the agenda of a committee in the House. Thus, the second part of Chapter 3 investigates the agenda setting choices of the chairs of the Small Business committee. This committee sees many women's issue bills, so it is appropriate to research more about the difference between male and female chairs and whether the committee has considered more women's issues under the leadership of women. Not only do I investigate the regular agendas of the committee, but I also look at the oversight agendas set forth by the four chairs in question. In order to make valid observations, I compare a female Republican to a female Democrat, as well as compare the two women's agendas to their male chair colleagues.

If women are more likely to prioritize and sponsor women's issues (Saint-Germain 1989; Swers 2002a; Thomas 1994; Thomas and Welch 1991) but they do not conduct hearings in the same way as men (Kathlene 1994), we should be interested to see if agendas differ for male and female chairs. Also, female chairs in state legislatures say they are more motivated by policy and 
people than by power (Rosenthal 1998). Therefore, I predict that women, because of their gender, personal interest, and policy interest, will put women's issues on their committee agendas at higher rates than their male counterparts. If female legislators prioritize women's issues and care more about policy goals than power, I can expect women to use the opportunity as chair to place women's issues on their regular and oversight agendas. I also expect women to prioritize women's issues by introducing bills of such a nature. In the next section, I will discuss Chapter 4, where I will examine whether certain district characteristics mediate the effect of gender when considering bill introductions.

Is gender conditioned by district and voter characteristics?

"Clearly, there is a lot more to a district than measures of vote share, income, urbanization, and demographics" (MacDonald and O'Brien; 474). This quote sums up the general inspiration and purpose of this chapter. When considering modeling the relationship between members of Congress and their bill introductions, I want to capture personal characteristics of the individual members as well as district characteristics in order to fully specify the model. Previous authors (Poggione 2004; Swers 2002a) took district into account by controlling for average household income, the percentage unemployed in the district, the percentage of district residents who earned a college degree, and urbanicity. What if the effects of gender are mediated by a district characteristic? Or more importantly, what if gender is mediated by a district characteristic specifically related to the women of the district?

Female legislators have expressed a sense of responsibility to represent the interests of women and they are more likely than men to view women as a distinct part of their constituencies (Carroll 2002; Dodson et al. 1995; Foerstel and Foerstel 1996; Gertzog 1995; Reingold 1992, 
2000; Rosenthal 1998; Thomas 1994, 1997). What if women act with their female constituency in mind? What if, in the vein of Fenno (1978), women act with their female reelection constituency in mind? We know from Fenno that there are different constituencies within a district, so women might have advantages building these constituencies relative to a man. So, their gender has an effect, but is it gender in conjunction with being in the right district? These are important questions to address since the literature is not addressing them currently. In this chapter, I will address these questions of gender interacting with district characteristics by examining bill introductions.

Swers calls gender a "fundamental identity that affects the way Senators look at policy questions, the issues they prioritize, and the perspective they bring to develop solutions" (2013; 3). However, the fundamental identity is not enough to explain behavioral differences between male and female members. She goes on to argue that senators develop political and electoral strategies based on public expectations regarding gender roles and party reputations, which is further expanded on in more recent work (see Swers 2016a \& 2016b). If we take her findings into account along with the previous discussion of Fenno, it is easy to see how important it is to account for the member's gender and the member's district characteristics. Plus, we can expect certain kinds of districts to elect Democratic and Republican women (Palmer and Simon 2006). Perhaps female legislators keep the women of their district in mind for both personal interest, like Hall would expect, and for reelection interests, like Fenno would expect.

When women are able to pursue any issue that interests them and their constituents, they choose to introduce legislation related to gender and family (Swers 2002a). When examining state legislatures, Bratton (2005) finds that women sponsor more women's interest legislation than their male counterparts, even when the legislature contains very few women. I expect being female to have a positive relationship with bill introductions related to women's issues based on these 
previous findings. I also expect that some of the interactions I include to condition the effects of gender. Specifically, I expect being female to interact with district characteristics related to women, such as the number of single moms or the number of women business owners in the district. These are factors that have the potential to characterize the types of voters in the district that would prioritize women's issues, and thus characterize how they would expect their representative to respond accordingly. Therefore, we might expect female representatives to exploit gender through their "linked fate" (Dawson 1994) with female voters, but we also might expect them to simply behave according to their own personal gendered identity.

It is important to consider both the extent to which gender motivates behavior on its own, as a fundamental identity (Swers 2013), and in conjunction with reelection and district motivations. Therefore, I think it is crucial to consider the constituents living within the district, especially the women who are probably paying attention to whether their representative is voicing concerns that are unique to them. Certain district characteristics, such as the types of women living within them, will "activate" congresswomen to attend to women's issues, though the same district characteristics should not activate congressmen in the same way. Rather, I am arguing that congresswomen will be in the unique position to capitalize on representing women within their districts by introducing women's issue legislation and hoping to reap the rewards of reelection. If gender turns out to be a significant motivating factor in bill introduction behavior, even if it is conditioned by other personal or political characteristics, then we can successfully connect descriptive and substantive representation. This would also bolster Mansbridge's (1999) claims that descriptive representation enhances substantive representation through improving the quality of deliberation. In the case of this dissertation, deliberation refers to congressional hearings, oversight hearings, and bill introductions, all considering women's issues. 


\section{Conclusion}

This literature review has drawn from work that has studied both the participation of women in government and the more general literature considering the motivations and actions of members of Congress. In the following chapters, I will investigate three different aspects of lawmaking (participation in committee hearings considering women's issue bills, conducting oversight of women's issue legislation, and the introduction of feminist and social welfare bills) to determine if and how congresswomen participate differently than their male colleagues. Because I expect that women are inherently different, this dissertation is an important contribution to the academic discussion on the link between descriptive and substantive representation. If electing women leads to different results, both in the kind of representation that they exhibit and the policies they help produce, then this is an important implication for the functioning of our democracy. Furthermore, if electing more women leads to policies that benefit the female citizenry in particular, than it is important to elect more women. 


\section{Chapter 1 Figure}

Figure 1.1: Women in the House and Senate by Party (1917-2017)

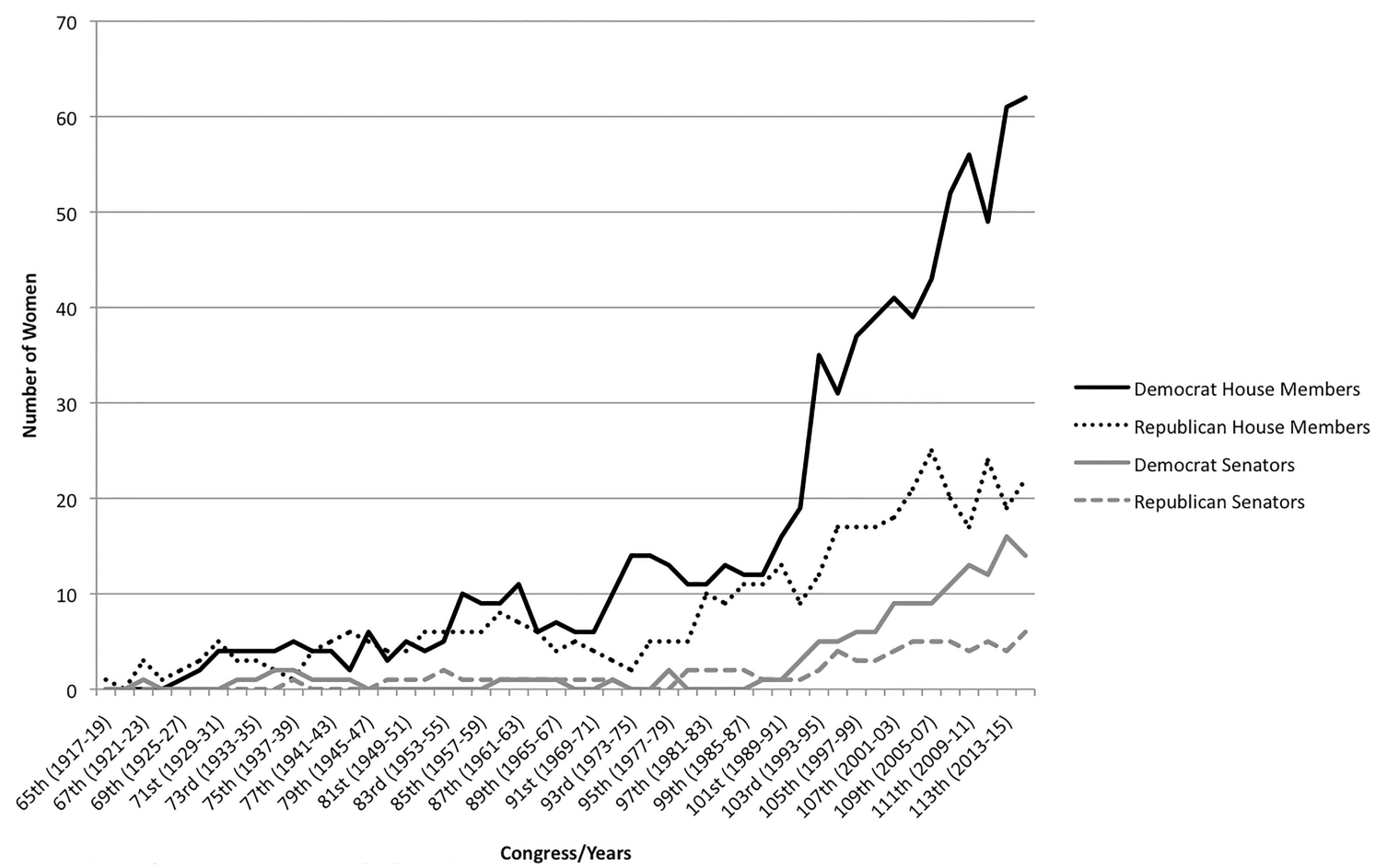

Source: Center for American Women and Politics (Eagleton Institute of Politics at Rutgers, The State University of New Jersey), 2015. 


\section{Chapter 2: \\ Participation of Members of Congress in Committee Hearings Considering Women's Issues}

Research on Congressional behavior tends to focus on what motivates individual legislators to act. There are two main camps in this area of literature: those that present a singular motivating factor and those that present multiple motivating factors. In the first camp, Fiorina (1974) and Mayhew (1974) tell us that all actions of members of Congress can be explained by their goal to be reelected. This goal underpins all action, even if the action may seem, on the surface, removed from campaigning. The second camp includes Arnold (1990), Hall (1996), and Fenno (1978) who present a slightly more nuanced picture of motivation and behavior. These authors discuss both personal and electoral interests as motivations for behavior and decision making. Each member has come to serve because they want to engage in policy formulation. If they are active in committee, it is very likely they are interested in the issue. Past research has also considered the role of gender in congressional behavior (e.g., Swers 1998; 2002; 2013). This literature tends to focus on whether there is a connection between descriptive and substantive representation ${ }^{10}$. The kinds of bills women sponsor or cosponsor, their participation in floor debate, and the amendments they offer are just some of the more recent areas of participation that have been examined by political science. Some scholars have challenged the descriptive and substantive representation connection, showing that party and ideology are stronger predictors of behavior. This chapter seeks to reestablish the descriptive and substantive connection.

With particular inspiration from Hall (1996) and Swers (2002), the current chapter asks: Do women participate more on women's issue bills in order to get these bills passed than their

\footnotetext{
${ }^{10}$ Descriptive representation is the extent to which a representative resembles those being represented, while substantive representation is the actions taken on the behalf of or in the interest of constituents (Pitkin 1967).
} 
male colleagues? I structure part of my argument around Hall's contention that if a member is interested in a policy, they participate more in committee. I also borrow from Hall by using chairs as a comparison to the rest of the committee members for the amount of individual participation. From Hall (1996), we know chairs have more resources, so we may predict that they would be more active in all instances during hearings. If other members, such as women, are more active than the chairs (who in both bill cases happen to be all male), it shows the particular importance of such participation despite a lack of resources.

From the congressional literature considering gender, I hope to show that party and gender have separate effects and that gender effects participation more than party. I will measure participation through analysis of committee hearings. I count the number of testimonies (or the number of times each member speaks) per member per hearing, the total number of words per member per hearing, and the total number of questions asked per member per hearing. I also consider traceability's effect on participation by comparing a high-salience and low-salience bill: The Family and Medical Leave Act and the Commission on the Advancement of Women and Minorities in Science, Engineering, and Technology Development Act (hereafter the FMLA and the SET commission) ${ }^{11}$. We might expect to see gender have more of an effect in the SET commission models because it is less salient to the members' constituents, and therefore less traceable. Members can feel free to act based on personal beliefs and, to a certain extent, disregard constituent opinion. However, because I chose two bills that are not controversial or cut-and-dry partisan issues (like abortion or pay equity), I think women can express their personal, gendered interest in the bills. Again, we might see more of an effect in the less salient, less traceable SET commission hearings. Alternatively, since the FMLA was so salient, it may have been the case that

\footnotetext{
${ }^{11}$ Again, the timeframe spans 1985-1998 for both sets of hearings.
} 
female members paid more attention to it and participated more in order to take credit for doing so. When we look at it this way, the less salient SET commission is a check on the FMLA. If women participate at an equal level in both sets of hearings, then gender is the overarching motivational factor rather than salience and voter perception.

Overall, I predict that women will take more of an interest in passing these bills than their male colleagues and therefore participate more in committee hearings, thus providing greater substantive representation of women's interests. Therefore, my contribution is to examine whether gender improves representation while studying representational behavior that affects policy outcomes - that is closer to the decision point than prior studies of gender and representation. It is important to consider both the extent to which gender motivates behavior on its own, as a fundamental identity (Swers 2013), and in conjunction with partisanship, as well as voter opinions and perceptions. I seek to account for all motivating factors in my analyses. By doing so, we can accurately account for how important gender is, and if gender turns out to be a significant motivating factor, then we can successfully connect descriptive and substantive representation. This would also bolster Mansbridge's (1999) claims that descriptive representation enhances substantive representation through improving the quality of deliberation, in this case, in congressional hearings.

\section{How does gender effect the participation of members of Congress?}

Welch made the first major contribution to the female representation literature by investigating Congress and the gender differences within parties evidenced by voting behavior (1985). Comparing the parties overall, Republican and Democratic men and women were about the same distance apart on ideology scales. The largest gender difference occurred within the Southern Democratic group followed by the Republicans, while Northern Democrats of both sexes 
were so liberal and so close that women barely eclipsed men on the ideological scale. The controls closed the gaps in gender differences, but the differences remained significant. Vega and Firestone (1995) studied behavior in the form of roll call voting and bill introduction between 1981 and 1992. They wanted to know whether having women in Congress (descriptive representation) affects behavior and therefore affects substantive representation. Overall, women had slightly more liberal voting patterns than their male colleagues, and Republican women were statistically significantly more liberal than men in nine of the twelve years examined.

However, the gender gap within parties is closing with time. Bill introduction data for the same period reveals that congressional women are introducing women-related legislation proportionate to their number and not disproportionately more as might be expected. Vega and Firestone conclude that while their results are mixed, there is a potential for women of both parties to continue to vote similarly and therefore increase the connection between descriptive and substantive representation. Such findings are why I expect to see a strong connection between descriptive and substantive representation when examining FMLA and SET commission hearings. I expect women to participate in order to accomplish a policy goal that benefits women constituents.

Michele Swers is also concerned with determining the policy effects women have in Congress (1998). She specifically investigates behavior concerning women's issue votes. Her reasoning is simply that the more an issue directly affects women, the more likely women will vote together, disregarding party. She finds that gender exerts influence over voting behavior on women's issue bills, but ideology is a better predictor. Importantly, a pattern does emerge of Republican women defecting from party and voting for women's issues more than their male Republican colleagues. Also, her evidence refutes the notion that gender differences can be entirely 
explained by district characteristics. In fact, "districts with higher median household income are more supportive of women's issues" (Swers 1998, 440). Women's issues affect all women, across social and class differences. Bills that most effect women's health and reproductive issues drive the gender differences. Ideology, partisan, and district factors take over when considering the bills that dealt with peripheral issues, like education. No matter the party, congresswomen are more willing than congressmen to vote in favor of bills the purpose of which is to improve the wellbeing of women.

In order to substantiate these important findings, Swers (2002) examines five steps in the policy process to fully investigate gender differences within the parties: bill sponsorship, cosponsorship, amendments in committees, defending women's issues on the floor, and roll call voting. All five point to the conclusions drawn in her 1998 article: moderate Republican and most Democratic women are more willing to work for women's issues than men. Her most important finding for our purposes here is that the largest gender gap occurs in the sponsorship step of the process. This implies that when women are able to pursue any issue that interests them and their constituents, they choose to introduce legislation related to gender and family.

Although her finding on bill introductions is a strong indicator of the connection between gender and behavior, my current chapter seeks to better understand bill construction and the committee process. When considering amendments in committee, Swers (2002) admits her study “does not capture any pre-markup activity in which members work to convince the chair to include their proposals in the chairman's mark, the bill that will be subject to amendment during the markup" (78). This project specifically addresses this yet to be examined phenomenon. Also, as Swers (2002) mentions, members have to engage in persuasive behavior, which indicates their level of interest. The more interested they are in constructing the bill, the more they are going to 
participate in committee. In Norton's (2002) article, she discusses the findings of Hall who "contends that personal policy interests determine how actively members will participate on an issue once seated on the appropriate committees" (318). I believe my analysis will show that gender predicts participation on women's interest legislation.

Whereas the previously discussed literature examines gender as one of the various motivating factors of the individual, while controlling for some district characteristics, the other aspect of motivation I'm concerned with is the interaction of gender with campaigning. Do members of Congress use their gender to win elections and how is this connected with their behavior within the policymaking process? The idea of issue ownership, although somewhat intertwined with salience, developed out of the literatures on campaigning, framing, and voter decision-making. Politicians use their party's and their individual ownership of certain issues to "successfully frame the vote choice as a decision to be made in terms of problems facing the country that he is better able to 'handle' than his opponent" (Petrocik 1996). Other literature points to the positive response of voters to candidates running on their personal legislative record and to candidates who avoid making bogus claims about said record (Sellers 1998).

Because I argue that interest should outweigh reelection concerns, I specifically test for the differences in both gender and party. According to Petrocik (1996), a "personal characteristic can convey ownership of an issue: gender can determine who is the more credible candidate on matters of sex discrimination, a retired war hero is a particularly credible commentator on military security. Issue handling competence is the key" (847). Therefore, we might expect women to exploit gender through their "linked fate" with female voters, but we also might expect them to simply behave according to their own personal gendered identity. Because Democrats in recent years have successfully framed parts of the Republican policy agenda as a "war on women", I expect to see 
higher levels of participation from both male and female Democrats. Democrats now safely "own" women's issues, so men and women should exhibit similar levels of behavior within this party. However, considering personal policy interests, a kind of personal issue ownership, we should also pay particular attention to the participation of female Democrats and Republicans ${ }^{12}$. Party can provide a simple cognitive shortcut to the voter (Popkin 1991), but gender may contradict such shortcuts. In other words, do female Republican candidates attempt to own women and family issues just as much as female Democrats? I think the answer is "yes." Female Republicans will participate more than their male colleagues in order to pass the FMLA and the SET commission bills. Again, traceability fits into this puzzle, however, so we may expect differences based on salience and political calculations.

I have used the previous paragraphs to examine the differences in political behavior of men and women of Congress and to discuss the interaction of gender with voter perceptions. The following research design will explain how I plan to show that gender affects committee participation.

\section{HYPOTHESES}

My primary hypothesis is that women will participate at a higher level than men, in both parties, considering both of these bills. This means that women, both Democrats and Republicans will speak out more (number of testimonies), ask more questions, and speak the most (number of words) compared to their male colleagues. I expect positive and statistically significant

\footnotetext{
${ }^{12}$ Swers (2016A) notes evidence of party polarization in the $107^{\text {th }}$ and $108^{\text {th }}$ legislative sessions among women, however varying on different policy areas. Her work in that article focuses on the Senate, which means we cannot take the evidence as directly transferable to the House. Although Democrats and Republicans differ on their approach to women's issues during the years presented in the current chapter, we cannot strongly point to rhetoric akin to what we have experienced in the recent past with the "war on women" frame employed by Democrats to delegitimize any claims Republicans may attempt to make on women's issues.
} 
relationships between gender and all three dependent variables measuring participation. Also, I anticipate a higher level of activity during the highly salient FMLA, as members will want to claim credit, and less activity during the less salient SET commission. Procedurally, it may be expected that chairs will speak the most often in a hearing. If women are observed to speak more than chairs, thus expending more resources than chairs who have much more resources comparatively, then women are only further proving their dedication to the bill's passage.

If the member has little to no interest, we can expect they will either not testify at all or have only a very small statement to make, or have only one or two questions to ask. On the other hand, if the member has been a primary supporter from the beginning, or has grown to accept the bill based on compromises made in committee, s/he will testify a great deal, have much to say, and ask many pointed questions in hopes of persuading the undecided members or compromising with the opposition. The comparisons of the amount of behavior between committee members will show who acts more in a hearing, displaying who has the most personal interest in the bill, and thereby the most interest in getting the bill to the floor and subsequently passed. Women, no matter their party, should have the most interest and therefore participate the most when working to get a women's issue bill to the floor. We must also pay attention to female Republicans, in particular, because if they participate at a high level, they may be attempting to steal the ownership of women's issues from Democrats.

\section{DATA AND Key MeASURES}

The ways previous scholars have identified gender differences in legislative behavior include comparing the amount of roll call votes between the sexes on women's issue bills, bill introductions, amendments in committee, and ideology scores. Committee behavior, however, has not been examined. This is a serious oversight considering committee hearings are where 
important negotiations occur and bills are created and marked up. Using the FMLA and the SET commission hearings, I examine the transcripts to see who participated more on each bill. These behaviors include testifying and asking questions or making statements. By measuring the amount of behavior, I hope to capture how much effort each member put into participating during the crafting of the legislation.

DATA AND VARIABLES ${ }^{13}$. The datasets consist of data that I have personally collected for the dependent variables as well as demographic data from several sources. The dependent variables, which are count variables, have been collected from congressional hearing transcripts. From the transcripts, I also gathered two dummies: one for ranking member and one for chair. Independent variables like party and ideology measurements are included (Carroll et al. 2009; Poole and Rosenthal $2007^{14}$ ) as well as personal characteristics of the members, such as gender and race (ICPSR 7803; MacDonald and O'Brien 2010 ${ }^{15}$ ). The demographic data about the members' districts include the urban population, median family income, and African American population (Adler $2002^{16}$ ).

Transcripts for the hearings considering the FMLA and SET Commission were found using ProQuest Congressional (formerly Lexis-Nexis Congressional) and were examined online via HathiTrust digital library ${ }^{17}$. All of the models use gender and party identification as the independent variables of interest and the three different dependent variables are (1) number of times the legislator spoke, (2) the amount of words spoken, and (3) the number of questions asked

\footnotetext{
${ }^{13}$ Data sources, definitions, and descriptive statistics for Chapter 2 can be found in Table A2.1 of the Appendix.

${ }^{14}$ Data on partisanship and ideology was obtained from the DW-Nominate data that Keith Poole makes available freely at www.voteview.com. I thank him for making these data available.

${ }^{15}$ I thank Jason MacDonald and Erin O'Brien for sharing these variables with me, especially as they were already formatted for use.

${ }^{16}$ I thank E. Scott Adler for making data on congressional districts publicly available.

${ }^{17}$ https://www.hathitrust.org/
} 
for each hearing. With the independent variables, I am explaining which personal characteristics affect lawmakers' participation. The dependent variables show the amount of behavior that occurs when working on a bill in committee. The dependent variables are examined in three models per bill. The number of testimonies, the number of questions, and the number of words are summed separately for each member for each congressional hearing ${ }^{18}$. Of course, if multiple committees examined a bill, each committee's testimonies will be examined. Therefore, the unit of analysis is the member-hearing pair, as members attended (or did not attend) multiple hearings.

Gender, my main independent variable, and party will be simply coded as dummy variables $(1=$ female, $0=$ male and $1=$ Democrat, $0=$ Republican $)$. I also included variables to measure seniority---a dummy variable to control for chairmanship ( $1=$ chair, $0=$ otherwise $)$ and a count variable for number of terms served by members. These variables attempt to explain the propensity of established members to ask more questions. The chairmanship variable also controls for the amount of times the chair needs to speak procedurally. Chairs are also important for comparison. As previously mentioned, chairs have more resources, so we might expect them to participate more in all instances. It is worth comparing the actions of all other members with the chairs for this reason. The hearing dummy variables control for any effects that a particular hearing may have on the models. There are nine hearings total, so "Hearing 0 (zero)" is the reference category. I also controlled for the same variables that were mentioned in the literature, but specifically what Swers $(1998 ; 2002)$ controls for. She identifies personal variables (African American: 1 = African American representative, $0=$ otherwise; Southern: $1=$ from a Southern state, $0=$ otherwise) and

\footnotetext{
${ }^{18}$ To record the number of words, I counted the number of lines per page and then calculated the average number of words per line (seven). This works because the size of the font and the style of the transcripts are consistent in the online PDFs, so counting by number of lines is valid.
} 
district characteristics (population of the district that is urban, the median household income, and the population of the district that is black).

\section{RESULTS}

FMLA

During the course of the FMLA hearings, I observe behavior from twelve Democratic women, one hundred-fifteen Democratic men, eight Republican women, and seventy-two Republican men. Table 2.1 displays the results of the three separate negative binomial regression models. Here, we can see that gender has a positive and statistically significant effect in all three models confirming all three hypotheses: being a woman makes the member more likely to participate when compared to their male colleagues. Significance is reached at the $p<0.001$ level for number of testimonies, and $\mathrm{p}<0.01$ for number of words and number of questions. As predicted, female members of Congress speak more often, in greater volume, and ask more questions than their male counterparts, thus participating overall more than men. This is especially important due to the fact that party is not a statistically significant predictor of behavior, nor are the district characteristics. Considering that women are clearly a minority in the institution, as well as within these committee hearings, the results are even more important. The African American variable has a positive and statistically significant relationship to the number of testimonies and the number of questions, indicating black members' propensity to participate more ${ }^{19}$. This is interesting, perhaps indicating that black members of Congress recognize the importance of providing and protecting human rights, in this case, the right to have a family without being penalized $^{20}$. The Southern variable is statistically significant in the testimony model, indicating the

\footnotetext{
${ }^{19}$ For the FMLA, there were 29 observations of black members out of 207 total observations. Recall the unit of analysis is member-hearing pair, so this doesn't mean there were 29 different black members.

${ }^{20}$ The FMLA provides 12 weeks of unpaid leave in any 12-month period for qualified medical (pregnancy is the primary concern) and family reasons. It also guarantees that individuals who take this leave will not
} 
Southern members speak out more during the hearings examined. Hearings 1 and 3 are also statistically significant in the testimony model indicating that these hearings contribute a great deal to the model. Lastly, median family income is positively and statistically significantly related to number of testimonies and number of questions. This indicates that higher income within the members' districts is associated with more action during these hearings. This indicates that as median family income increases within a district, so does the participation of that representative. This makes sense because wealthy and educated people care more about women's issues in public opinion surveys (Lewis-Beck et al 2008).

Tables 2.2 and 2.3 expand the analysis to accommodate the possibility that gender and party are working together in the model as motivating factors for members of Congress. Perhaps being a female Democrat or female Republican is more explanatory, so separately modeling gender and party presents a limitation. I have constructed two interaction models in order to address this concern. In Table 2.2 (full estimates presented in Table A2.2 of Appendix), the interaction is constructed as an interaction term that statistically measures both the effect of gender and party identification in one variable. Here, the interaction term does not reach conventional levels of significance, indicating that partisanship does not condition the association between gender and participation. However, the base coefficient for gender is positively and significantly associated with participation. For a comparison, Table 2.3 (full estimates presented in Table A2.3 of Appendix) introduces interaction terms constructed as dichotomous dummy variables: female Democrats, female Republicans, and male Republicans, leaving out male Democrats as the reference category. The only coefficient to reach conventional levels of significance is female Democrat. Congresswomen of the Democratic party speak out about two more times than their

lose their job. In essence, the FMLA is a set of regulations providing leave and protection of the right to have a family for those who work in private and public sector companies with 50 or more employees. 
male colleagues. This means that in a policy area that Democrats tend to "own" (i.e., Petrocik 1996), women of the party are still taking the lead in participation. Female Republicans also outperform male Democrats at the $\mathrm{p}<.10$ level (it is .007 on the test statistic from being at the $\mathrm{p}<.05$ level), so it is confirmed that women in both parties are participating more than male Democrats. We can see that male Republicans lag behind the women of their party, so within each party the women are participating much more than their male colleagues. Coupled with the results from Table 2.1, it is important to realize the overall findings: congresswomen are more active in committee hearings considering the FMLA than are congressmen. Descriptive representation enhances substantive representation.

The predicted probability analyses ${ }^{21}$ are very interesting in that we can visualize the differences in behavior between men and women by party identification. The results are presented in Figures 2.1, 2.2, and 2.3. Women are still much more active than men considering all three behaviors, but here we see the effect that chairs have in the model $^{22}$. In Figure 2.1, Democratic women are predicted to speak 7 more times than Democratic men, while Republican women are predicted to speak 6.7 more times than Republican men. Chairs speak 4.1 times less than Democratic women and 3.6 less times than Republican women. Figure 2.2 deals with number of words. Democratic women speak 10.2 times more than their male colleagues, while Republican women speak 9.3 times more than their male colleagues. Note that in Figure 2.2, I removed the chairs from the model because their results dwarfed the results of the other four categories. This is expected due to the procedural role taken on by the chairs. They must speak to all of the witnesses and run the hearing, calling on and engaging every other member that speaks. I included the graph

\footnotetext{
${ }^{21}$ I used CLARIFY to predict the behaviors of typical members. From Gary King's website: http://gking.harvard.edu/publications/clarify-software-interpreting-and-presenting-statistical-results ${ }^{22}$ For the FMLA, all of the chairs were Democrats because during the congresses that considered the FMLA in committee, Democrats were in the majority.
} 
with the chair category remaining as Figure 2.2a. Figure 2.3 considers the number of questions, and again, female Democrats outperform their male colleagues by 3 questions and female Republicans outperform their male colleagues by 1.8 questions. Overall, it is clear based on the estimates that both female Democrats and female Republicans have the propensity to participate more during markup of the FMLA. This is consistent with the predictions made about the salience of the FMLA. Also, considering issue ownership, female Republicans may be attempting to highlight their participation in these hearings based on reelection goals.

\section{SET Commission}

During the course of the SET commission hearings, I observe fourteen Democratic women, fifty-nine Democratic men, seven Republican women, and fifty-four Republican men. In Table 2.4, I consider the results for the negative binomial regressions for the SET commission. Again, the effect of gender is exhibited, this time in two out of three models. I can safely say that being female has a positive and statistically significant relationship with participation. For the number of testimonies model, significance occurs at the $\mathrm{p}<0.01$ level, and for the number of words model, significance occurs at the $\mathrm{p}<0.05$ level. Also, consistent with the results for the FMLA, party does not reach statistical significance, indicating that party does not affect participation as much as gender. Remember, I predicted that the effect of being female might not hold for both the salient FMLA and the less salient SET commission. However, I find in the less salient case that female members have a greater propensity to participate as well, none of the control variables reach significance in this model. Again, the importance of gender is impressive considering the small number of women participating in the hearings. This means, as it did with the FMLA, that women are dominating the conversation on women's issues. Congresswomen are asserting themselves in 
order to act on these bills, further showing they are willing to expend resources and represent the needs of women constituents.

Tables 2.5 and 2.6 present results of the models considering interaction terms (full estimates presented in Tables A2.4 and A2.5 of Appendix). Table 2.5 shows us, again, that effectively controlling for the interaction term, coupling together a member's gender and party identification, being a congresswoman still plays a statistically significant role. For the SET commission hearings, both the number of times testifying and the volume of speech attain statistical significance. This indicates that being a woman is a strong determining factor in participation in these kinds of hearings. Table 2.6 confronts us with some particularly interesting results. Not only do female Democrats (again, as we saw with the FMLA) speak out about 3 times more often than do male Democrats at a statistically significant level, but female Republicans also participate more. In fact, female Republicans speak more, in volume, and more often than their male Democratic colleagues at the $\mathrm{p}<0.05$ level. These are impressive results: Republican women are out-participating Democratic men, even though this is an issue area where we would expect high levels of participation from male Democrats. This again helps us further establish the link between descriptive and substantive representation. Both Republican and Democratic congresswomen are actively engaging in committee hearings considering the SET commission, indicating to the observer that they truly wish to represent the unique needs of their female constituency.

Again, the predicted probability analysis helps us visualize the results that I observed in the negative binomial regression analysis. Figure 2.4 shows a marked difference between men and women's actions. Democratic women and Republican women speak more often than their male colleagues. Democratic women speak 8.9 more times than Democratic men, and Republican 
women speak 8 more times than Republican men. I included Figure 2.4a, where you can see that chairs $^{23}$ clearly speak much more often, due to their role within committee proceedings. I excluded the chairs from Figure 2.4 because the results dwarfed the results of the other four categories. Figure 2.5 compares the actions of male and female Democrats and Republicans by number of words. Again, we see that women participate at a much higher rate than their male colleagues. Democratic women speak 14.4 more words than their male colleagues, while Republican women speak 11.9 more words than their male colleagues. Also, in this case, chairs and Democratic women are performing at similar levels. Finally, Figure 2.6 compares parties and gender for number of questions. Again, gender matters and both Democratic and Republican women outperform their male colleagues, with female Democrats asking 1.3 more questions than their male colleagues and female Republicans asking 2.37 more questions than their male colleagues. Chairs are not predicted to ask any questions. All three figures tell us something very important: that during committee hearings considering the SET commission bill, gender significantly affects behavior and women participate more. Also, despite what I expected, women participate more than men during both the salient and traceable FMLA and the less salient and non-traceable SET commission. This indicates that gender motivates participation more so than reelection, at least for these two cases. Plus, Democrats participate at higher levels than Republicans, which is consistent with their ownership of women's issues. However, because female Republicans participate at higher levels than their male colleagues, we might take this as evidence that female Republicans are looking to highlight their legislative accomplishments on women's issue bills, stealing ownership away from Democrats.

\footnotetext{
${ }^{23}$ During the congressional sessions that considered the SET commission in committee, both Democrats and Republicans took turns being the majority party, so there is just a designation of chairs here rather than Democratic chairs for the FMLA.
} 


\section{LEGISLATIVE ENTREPRENEURSHIP}

Before concluding, I pause to consider whether women may simply have the propensity to participate more than men no matter the issue area. This is a valid critique of the analysis presented above. What if congresswomen simply participate more than congressmen, in general? I think that if women are more active in the legislative process, it is due to their entrepreneurial style. Research on legislative effectiveness finds that congresswomen can be more effective than congressmen at shepherding "agenda items through the legislative process and into law" (Volden, Wiseman, and Wittmer 2013; 327). Legislative effectiveness and entrepreneurship are related: effectiveness is in part a function of entrepreneurship. Members who are more entrepreneurial should be more effective. Therefore, I will use entrepreneurship as a robustness check, ruling out the argument that women simply participate more than men.

If I observe women being more entrepreneurial than men, I suppose it would be for the same reasons they are more effective: they are more qualified and collaborative than their male colleagues. I'd also like to address institutional effects, like whether being a member of the majority or minority party affects women's propensity to be entrepreneurial. Unfortunately, for the entire span of the available entrepreneurship data, the majority and minority parties remained constant. However, I account for the differences that may occur between minority and majority party women with additional models that include variables that account for party identification and gender.

\section{LE Data and Methods}

Legislative entrepreneurship scores are the dependent variables in all the OLS regression models presented (Wawro $2000^{24}$ ). Personal characteristics of House members come from various

\footnotetext{
${ }^{24}$ I thank Greg Wawro for making the LE scores publicly available.
} 
sources $^{25}$. My main independent variable of interest, female, is coded 1 if the member is a woman, zero if the member is a man. Majority party is used to measure partisanship, and is coded 1 if the member is a Democrat, which was the majority party for the entire time period being studied; 0 if the member is a Republican. In one model, I also include four variables that account for both gender and partisanship instead of using the female and majority party variables. Here I code whether the members are female Democrats, female Republicans, male Democrats, or male Republicans, where 1 indicates the member is one of those categories, 0 if they are not. In the model, I leave out male Democrats as the reference category. For ideology, I use both DWNOMINATE first and second dimension scores because they are not correlated during this time period $^{26}$. Dimension 1 captures economic issues and the second dimension captures cultural and lifestyle issues. From the DW-NOMINATE scores I created two additional measures of ideology: distance from the majority party median and distance from the chamber median. These measures help us tease out whether certain types of members, either more liberal or more conservative, have the propensity to be entrepreneurial. I also note racial and ethnic characteristics, coding 1 if the members are identified as African American or Latino, 0 if they are not. In order to measure positions of authority and experience, I included the variables of committee chair, ranking member, and seniority. Committee chair and ranking member are coded 1 if the member had such as position, 0 if they did not. Seniority is the number of terms that a member served. Then, I accounted for different committee assignments and coded whether members were members of prestigious, constituency, or policy committees, based on Deering and Smith (1997). Prestigious committees are Appropriations, Budget, Rules, and Ways \& Means. Constituency committees are Agriculture, Armed Services, Interior, Merchant Marine, Public Works, Science, Space, \&

\footnotetext{
${ }^{25}$ See Table A2.1 for full list of data sources, definitions, and descriptive statistics.

${ }^{26}$ Correlation $=-0.0950$
} 
Technology, Small Business, and Veterans Affairs. Policy committees are Banking, Education \& Labor, Energy \& Commerce, Foreign Affairs, Judiciary, and Government Operations.

There are two analyses: one to explain legislative entrepreneurship within each congressional session, from the $94^{\text {th }}-103^{\text {rd }}$, and one that accounts for the entire time period. Because the second analysis includes all of the data for the entire time period, I ran these four models with congress-specific fixed effects, where each congressional session was accounted for with a dummy variable and I left out the $103^{\text {rd }}$ Congress as the reference category. In the following section, I discuss the results of the various models and whether or not my predictions about women being more entrepreneurial than men are supported.

\section{LE Findings}

Table 2.7 shows the four OLS regression models I ran in order to investigate hypothesis 3 (Full estimates are presented in Tables A2.6 and A2.7 in the Appendix). Prestigious and distributive committees are somewhat correlated, so I left out the distributive dummy in these models, as well as policy committees. In all four models, the coefficient for female is positive and statistically significant. Women are more entrepreneurial than men.

Models 1 and 2 consider partisanship, while models 3 and 4 consider ideology. In model 1 , there is a strong, positive, statistically significant coefficient for being a member of the majority party, indicating that they are more likely to be entrepreneurial than members of the minority. This is to be expected, since when you are in the position of majority, it should be easier to be effective and therefore entrepreneurial. However, this statistical effect disappears when I swap distance from the chamber median with distance from the majority party median. In model 2 , the coefficient for majority party remains positive, but loses significance, while the coefficient for the distance 
from the majority party is negative and strongly statistically significant. This indicates that the farther an individual's position from the majority party median, the less entrepreneurial they are. Models 1 and 2 complement each other, then, because they both indicate that being a Democrat indicates a higher level of entrepreneurship. Models 3 and 4 utilize DW-NOMINATE scores instead of party identification. In both models and for both dimensions, the more liberal a member is, the more entrepreneurial they are. These results are consistent with models 1 and 2 , since Democrats are more liberal than Republicans on average.

In all four models, race does not play a significant role. Measurements of seniority and experience do play significant roles. Being the Speaker of the House or a ranking member is negatively associated with entrepreneurship. Committee chairpersonship, however, appears to spur entrepreneurial behavior. These findings on party leadership match the previous paragraph's discussion on being a member of the majority party versus the minority party. Seniority, or the number of terms served, also plays a significant role. The more terms a member serves, the more likely they are to be entrepreneurial. Finally, membership on prestigious committees (Appropriations, Budget, Rules, and Ways and Means) enhances entrepreneurship.

In Table 2.8, I ran one model per congressional session, where the scaled entrepreneurship score is the dependent variable. I chose to simply present the coefficients for being a congresswoman, as the entire table is quite large and visually overwhelming. However, Table A2.8 in the Appendix presents the full estimates. Women are statistically significantly more entrepreneurial than their male colleagues in the $98^{\text {th }}, 99^{\text {th }}, 102^{\text {nd }}$, and $103^{\text {rd }}$ congresses. Women are more entrepreneurial in later sessions, which is consistent with the steady increase of women serving over time. However, the coefficients for female in the $100^{\text {th }}$ and $101^{\text {st }}$ congress fail to attain statistical significance. One can view the coefficient for "female" as a random variable. In this 
way, even if congresswomen engage in higher levels of entrepreneurship when relatively high levels of congresswomen populate the House, we will not always observe a positive statistically significant coefficient. In four of the six later sessions, though, this coefficient attains conventional levels of significance. In the other models, the coefficient is in the expected direction. On the whole, these findings at least suggest that congresswomen became more entrepreneurial toward the later part of the time span I examine. Alternatively, if fewer women are serving in Congress, we might expect them to be more entrepreneurial in order to combat the negative effects of tokenism. I do not observe this pattern. Women are not statistically significantly more entrepreneurial than men until the $98^{\text {th }}$ Congress. Again, women do not seem to be more entrepreneurial when there are fewer of them, rather, they are entrepreneurial when there are more, but not in a consistent way. For example, in the $101^{\text {st }}$ Congress, there are 29 women serving, but being female is not statistically significant in the model; however, in the $102^{\text {nd }}$ Congress with 28 women, being female is statistically significant.

In Table 2.9, I display the coefficients for female Democrats, female Republicans, and male Republicans, with male Democrats as the reference category. The full model, which can be found in the Appendix (Table A2.9), uses the same independent variables as the models presented in the previous analyses, except here, majority party and ideology are replaced by these gender-party variables. As you can see, women no matter their party are more entrepreneurial than the typical member, a male Democrat. Therefore, being a member of the majority party (Democrat) versus minority party (Republican) does not make a difference for women. Congresswomen of both parties are more entrepreneurial than the reference category, male Democrats.

To visually represent the difference between men and women, I present a predicted probability graph in Figure 2.7. Here, the comparison made is between male and female Democrats 
and male and female Republicans. The average entrepreneurship score during this time period was 61 and the maximum was 494.5. Considering the standard deviation of 41.4 entrepreneurship points, Democratic women are predicted to be between one-third and one-quarter of a standard deviation more entrepreneurial than Democratic men and approximately three-quarters of a standard deviation more entrepreneurial than Republican men. Female Republicans and male Democrats are the closest groups considering they are about five predicted entrepreneurship points apart, where the Democratic men slightly edge out the Republican women. Most important for consideration is the fact that Republican women are between one-half and one-third of a standard deviation more entrepreneurial than Republican men. Although the findings here differ slightly from the OLS models, the graph indicates that over time, all members are more entrepreneurial than male Republicans, but most importantly women out perform their male colleagues within party groups.

The fact that I observe a strong relationship between being a woman and being more entrepreneurial should only bolster the findings that women are more effective, despite being a numerical minority, and despite being members (over time) of the minority party. Although one can argue that these findings on entrepreneurship indicate a congresswoman's propensity to participate more than her male colleagues, I argue that two verdicts are more important for the current project: (1) the findings related to the two hearings examined earlier in the chapter further the link between substantive and descriptive representation, and (2) the findings on women's propensity to be more entrepreneurial than men indicates the importance of electing more women to Congress. Both of these findings bolster the literature by showing us that women make a substantial difference when elected to Congress. Not only are they able to affect real policy change via entrepreneurship, but also when they sit in on hearings that directly relate to women's issues, 
they participate more in order to facilitate that bill's progression through the policy process. By improving substantive representation as well as making Congress more productive, having women present improves Congress as a democratic policymaking institution.

\section{Discussion}

The main contribution of this chapter is to examine whether gender improves representation while studying representational behavior that directly affects policy outcomes. By analyzing committee-hearing transcripts, I show how gender strongly affects the behavior of legislators. According to the results presented here, I believe we can reinforce the connection between descriptive and substantive representation. In my investigation of the Family and Medical Leave Act and the Commission on the Advancement of Women and Minorities in Science, Engineering, and Technology Development Act, I found gender to be an important determinate of behavior, rather than party. Additionally, chairs did not participate more than all other members in all of the hearings. Instead, women outperformed chairs in three of the predicted probability figures, and came very close in Figure 2.3. Despite their lack of resources, as compared to chairs, women participated more, indicating their strong interest in bill passage. Again, gender significantly affected participation, and thus effected representation.

Another important finding has to do with issue ownership. Family and women's issues are usually considered to be issues of particular concern for Democrats, but we are confronted with evidence that tells a different story here, largely due to the high participation of female Republicans. I would expect both female and male Democrats to participate during the FMLA and SET commission hearings because Democrats own women's issues. This is displayed in the predicted probability figures, and Democrats do participate at higher levels than Republicans. However, due to the participation of female Republicans, we might say that they are attempting to 
steal ownership of women's issues due to their own gender. Issue ownership is complicated by its relationship to salience.

I chose to investigate the differences between the salient FMLA and the less salient SET commission throughout the chapter. By choosing both a salient and a less salient bill for comparison, I attempted to distinguish grandstanding, traceable behavior (Arnold 1990) from behavior where the member is truly interested in the policy content (Hall 1996). We might predict that gender would have more of an effect in the SET commission hearings because the behavior is less traceable and thus has less baring on reelection. However, I find that for both cases, the FMLA and the SET commission, being female is positively and significantly related to more participation. Thus, the concern for reelection is outweighed by interest in participating. Both the non-effect of party and the non-effect of traceability are important as it emphasizes the link between descriptive and substantive representation. Considering my results, American women may opt to vote for a descriptive representative, whom we can assume will also provide substantive representation.

In the next chapter, I revisit the hearing forum. If women are more participatory than their male counterparts, and women are more entrepreneurial, than I predict that we will observe that having women present on a committee will spur that committee to conduct more oversight hearings on women's issues. 


\section{Chapter 2 Tables and Figures}

Table 2.1: FMLA Negative Binomial Models for Number of Testimonies, Number of Words, and Number of Questions

\begin{tabular}{|c|c|c|c|}
\hline & $\begin{array}{l}\text { Number Times } \\
\text { Testifying }\end{array}$ & $\begin{array}{l}\text { Number of } \\
\text { Words }\end{array}$ & $\begin{array}{l}\text { Number of } \\
\text { Questions }\end{array}$ \\
\hline Congresswoman & $\begin{array}{l}2.49 * * * \\
(0.60)\end{array}$ & $\begin{array}{l}2.33^{* *} \\
(0.90)\end{array}$ & $\begin{array}{l}1.84 * * \\
(0.73)\end{array}$ \\
\hline Party Identification & $\begin{array}{l}0.23 \\
(0.43)\end{array}$ & $\begin{array}{l}-0.19 \\
(0.63)\end{array}$ & $\begin{array}{l}0.35 \\
(0.51)\end{array}$ \\
\hline African American & $\begin{array}{l}1.89 * * \\
(0.75)\end{array}$ & $\begin{array}{l}1.33 \\
(1.12)\end{array}$ & $\begin{array}{l}2.24 * * \\
(0.92)\end{array}$ \\
\hline South & $\begin{array}{l}1.17^{*} \\
(0.59)\end{array}$ & $\begin{array}{l}0.78 \\
(0.91)\end{array}$ & $\begin{array}{l}0.69 \\
(0.67)\end{array}$ \\
\hline Chair & $\begin{array}{l}1.02 \\
(1.02)\end{array}$ & $\begin{array}{l}1.02 \\
(1.58)\end{array}$ & $\begin{array}{l}1.90 \\
(1.19)\end{array}$ \\
\hline Number of Terms & $\begin{array}{l}0.035 \\
(0.05)\end{array}$ & $\begin{array}{l}0.068 \\
(0.08)\end{array}$ & $\begin{array}{l}-0.086 \\
(0.07)\end{array}$ \\
\hline Hearing 1 & $\begin{array}{l}1.45^{*} \\
(0.68)\end{array}$ & $\begin{array}{l}1.33 \\
(1.04)\end{array}$ & $\begin{array}{l}1.02 \\
(0.77)\end{array}$ \\
\hline Hearing 2 & $\begin{array}{l}0.77 \\
(0.67)\end{array}$ & $\begin{array}{l}0.78 \\
(1.00)\end{array}$ & $\begin{array}{l}0.74 \\
(0.81)\end{array}$ \\
\hline Hearing 3 & $\begin{array}{l}1.30^{*} \\
(0.71)\end{array}$ & $\begin{array}{l}1.63 \\
(1.10)\end{array}$ & $\begin{array}{l}1.04 \\
(0.80)\end{array}$ \\
\hline Hearing 4 & $\begin{array}{l}-0.043 \\
(0.83)\end{array}$ & $\begin{array}{l}0.72 \\
(1.22)\end{array}$ & $\begin{array}{l}-0.35 \\
(0.98)\end{array}$ \\
\hline Hearing 5 & $\begin{array}{l}0.34 \\
(0.71)\end{array}$ & $\begin{array}{l}0.95 \\
(1.08)\end{array}$ & $\begin{array}{l}0.36 \\
(0.84)\end{array}$ \\
\hline Hearing 6 & $\begin{array}{l}-0.20 \\
(0.85)\end{array}$ & $\begin{array}{l}0.50 \\
(1.18)\end{array}$ & $\begin{array}{l}-0.74 \\
(1.00)\end{array}$ \\
\hline Hearing 7 & $\begin{array}{l}-0.81 \\
(0.92)\end{array}$ & $\begin{array}{l}-0.76 \\
(1.38)\end{array}$ & $\begin{array}{l}-0.44 \\
(1.10)\end{array}$ \\
\hline Hearing 8 & -0.023 & 0.15 & -0.079 \\
\hline
\end{tabular}




\begin{tabular}{llll} 
& $(0.64)$ & $(0.98)$ & $(0.77)$ \\
Log Urban & 0.27 & 0.46 & 0.37 \\
Population & $(0.64)$ & $(0.93)$ & $(0.65)$ \\
& & & \\
Log Median & $1.89^{*}$ & $(1.89$ & $2.22^{*}$ \\
Family Income & $(0.15)$ & $(1.25)$ \\
Log Black & -0.13 & -0.053 & -0.21 \\
Population & $(0.15)$ & $(0.22)$ & $(0.18)$ \\
Constant & $-21.5^{*}$ & -21.0 & $-25.2 *$ \\
& $(9.27)$ & $(14.50)$ & $(11.65)$ \\
Log Alpha & $1.84^{* * *}$ & $2.74 * * *$ & $2.10^{* * *}$ \\
Constant & $(0.12)$ & $(0.11)$ & $(0.15)$ \\
\hline $\begin{array}{l}\text { N } \\
\text { Pseudo R-squared }\end{array}$ & 313 & 313 & 313 \\
\hline
\end{tabular}

Note: Variance exceeds the mean indicating negative binomial regression is appropriate. Standard errors in parentheses. ${ }^{*} \mathrm{p}<0.05, * * \mathrm{p}<0.01, * * * \mathrm{p}<0.001$

Table 2.2: Additional Negative Binomial Models of FMLA with Interaction Term

\begin{tabular}{llll}
\hline & $\begin{array}{l}\text { Number Times } \\
\text { Testifying }\end{array}$ & $\begin{array}{l}\text { Number of } \\
\text { Words }\end{array}$ & $\begin{array}{l}\text { Number of } \\
\text { Questions }\end{array}$ \\
\hline Congresswoman & $\begin{array}{l}2.14^{*} \\
(1.05)\end{array}$ & $\begin{array}{l}2.24 \\
(1.61)\end{array}$ & $\begin{array}{l}1.36 \\
(1.17)\end{array}$ \\
Party Identification & 0.36 & 0.21 & 0.25 \\
& $(0.56)$ & $(0.80)$ & $(0.59)$ \\
Congresswoman X & -0.31 & -0.68 & -2.62 \\
Party Identification & $(1.42)$ & $(2.13)$ & $(1.65)$ \\
\hline N & 207 & 207 & 207 \\
Pseudo R-squared & 0.04 & 0.01 & 0.04 \\
\hline
\end{tabular}

Note: Variance exceeds the mean indicating negative binomial regression is appropriate. Standard errors in parentheses. ${ }^{*} \mathrm{p}<0.05, * * \mathrm{p}<0.01,{ }^{* * *} \mathrm{p}<0.001$. Full estimates are provided in Table A2.2 of the Appendix.

Table 2.3: Additional Negative Binomial Models of FMLA with Interaction Dummy Terms

Number Times Number of Number of




\begin{tabular}{llll} 
& Testifying & Words & Questions \\
\hline Female Democrat & $1.83^{*}$ & 1.55 & -1.26 \\
& $(0.99)$ & $(1.42)$ & $(1.20)$ \\
Female Republican & 1.78 & 2.03 & 1.11 \\
& $(1.09)$ & $(1.62)$ & $(1.23)$ \\
Male Republican & -0.36 & -0.21 & -0.25 \\
& $(0.56)$ & $(0.80)$ & $(0.59)$ \\
\hline N & 207 & 207 & 207 \\
Pseudo R-squared & 0.04 & 0.01 & 0.04
\end{tabular}

Note: Variance exceeds the mean indicating negative binomial regression is appropriate. Standard errors in parentheses. ${ }^{*} \mathrm{p}<0.05,{ }^{*} \mathrm{p}<0.01,{ }^{* * *} \mathrm{p}<0.001$. Full estimates are provided in Table A2.3 of the Appendix. 
Figure 2.1:

Figure 1. Predicted Number of Times Speaking during FMLA Hearings

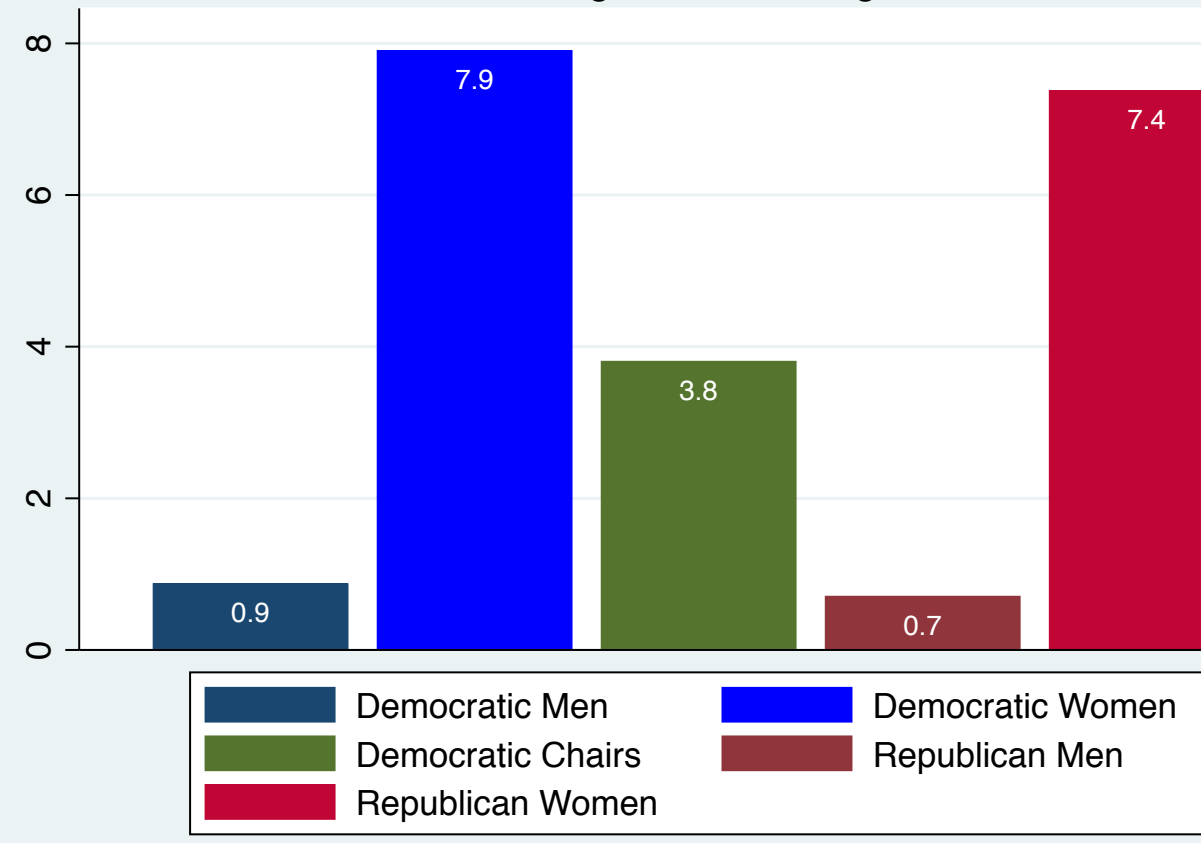

Figure 2.2:

Figure 2. Predicted Number of Words during FMLA Hearings

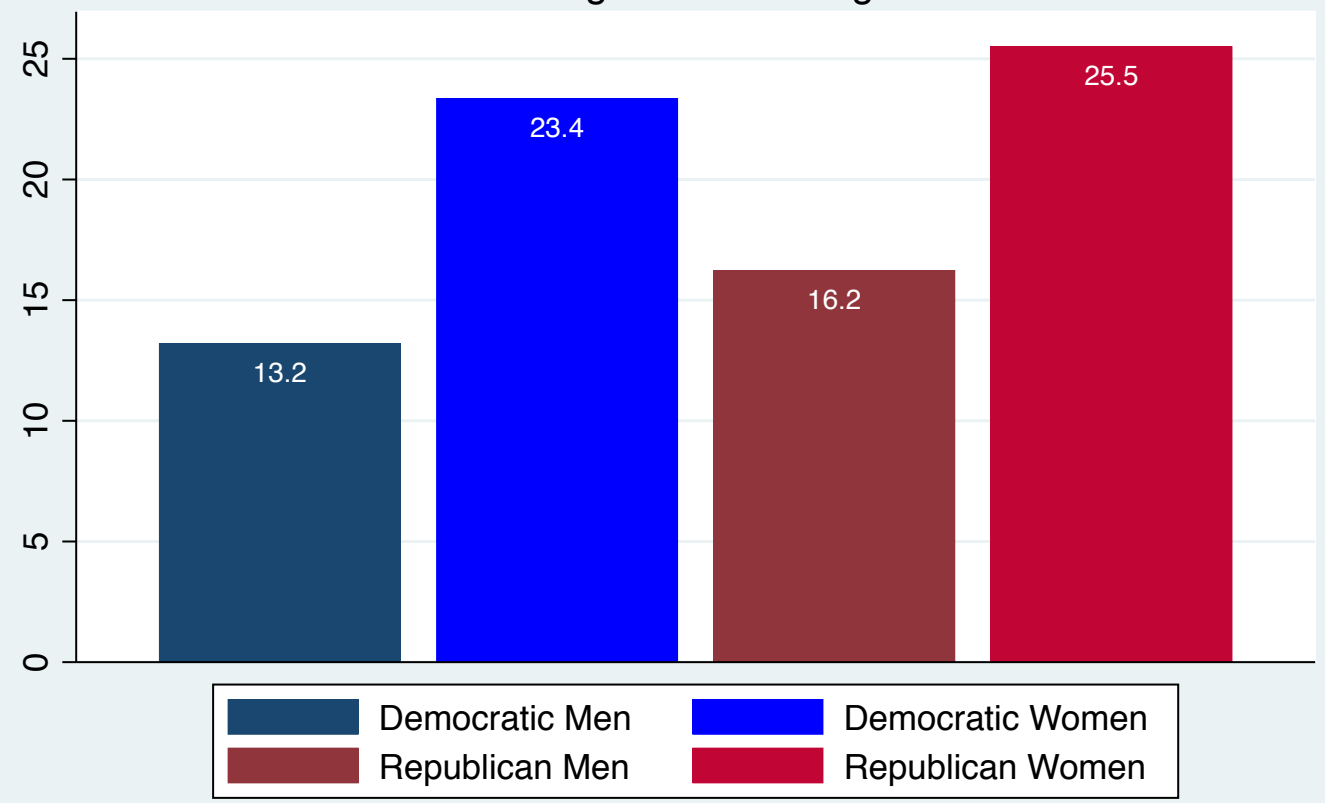

Note: Chairs excluded 
Figure 2.2a:

Figure 2a. Predicted Number of Words during FMLA Hearings

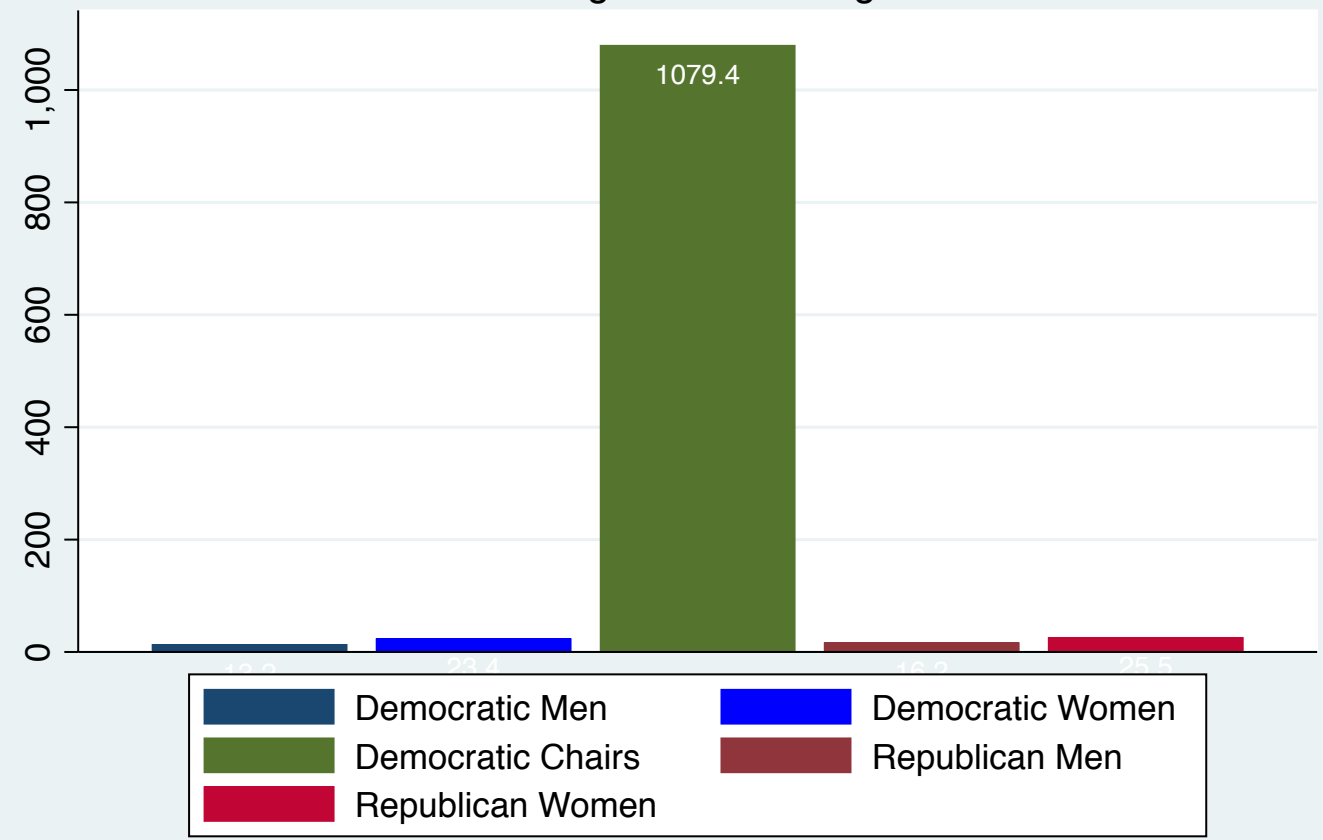

Figure 2.3:

Figure 3. Predicted Number of Questions during FMLA Hearings

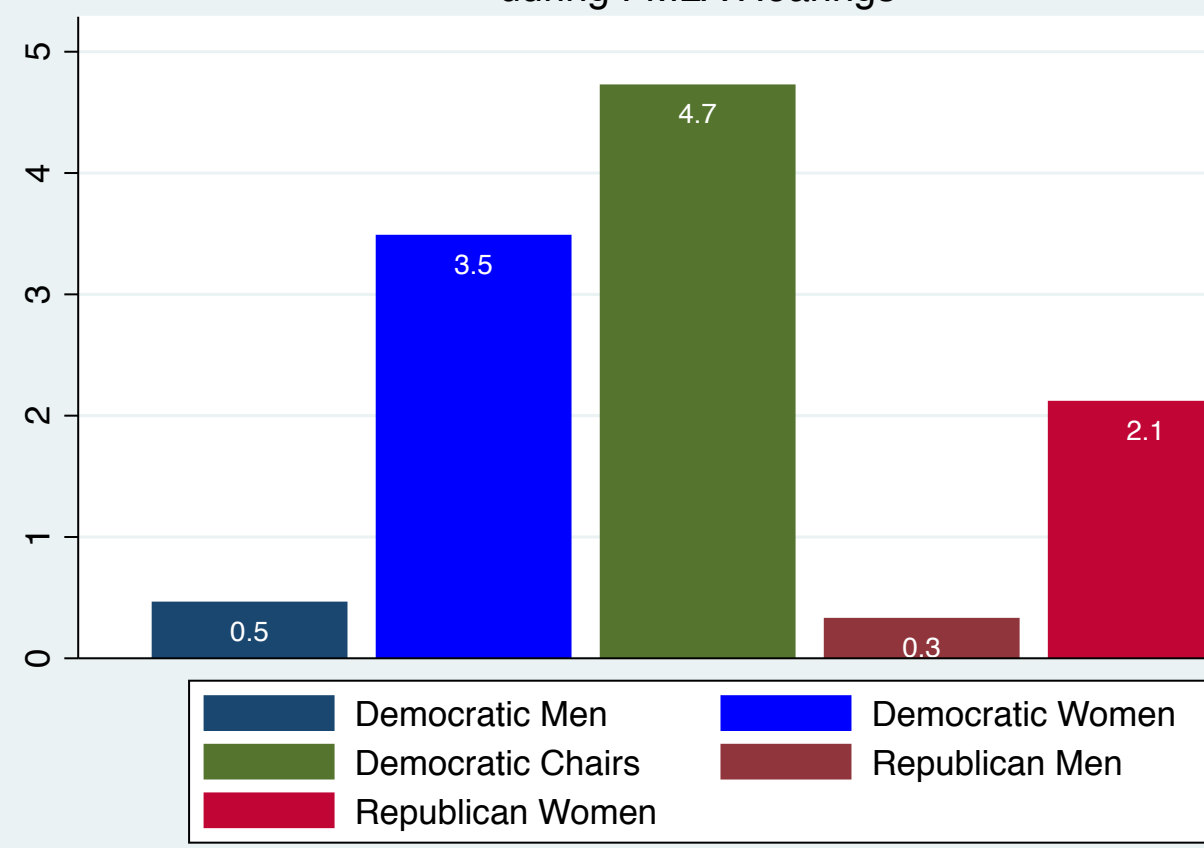


Table 2.4: SET Commission Negative Binomial Models for Number of Testimonies, Number of Words, and Number of Questions

\begin{tabular}{|c|c|c|c|}
\hline & $\begin{array}{l}\text { Number Times } \\
\text { Testifying }\end{array}$ & $\begin{array}{l}\text { Number of } \\
\text { Words }\end{array}$ & $\begin{array}{l}\text { Number of } \\
\text { Questions }\end{array}$ \\
\hline Congresswoman & $\begin{array}{l}3.63 * * \\
(1.45)\end{array}$ & $\begin{array}{l}6.65^{*} \\
(2.99)\end{array}$ & $\begin{array}{l}3.62 \\
(2.47)\end{array}$ \\
\hline Party Identification & $\begin{array}{l}0.41 \\
(0.84)\end{array}$ & $\begin{array}{l}0.58 \\
(1.40)\end{array}$ & $\begin{array}{l}2.18 \\
(1.75)\end{array}$ \\
\hline African American & $\begin{array}{l}-20.4 \\
(8.26)\end{array}$ & $\begin{array}{l}-30.7 \\
(13.30)\end{array}$ & $\begin{array}{l}-25.0 \\
(11.55)\end{array}$ \\
\hline South & $\begin{array}{l}-0.72 \\
(1.19)\end{array}$ & $\begin{array}{l}-3.49 \\
(2.57)\end{array}$ & $\begin{array}{l}-0.28 \\
(2.17)\end{array}$ \\
\hline Chair & $\begin{array}{l}1.46 \\
(3.25)\end{array}$ & $\begin{array}{l}5.89 \\
(6.63)\end{array}$ & $\begin{array}{l}-22.5 \\
(10.25)\end{array}$ \\
\hline Number of Terms & $\begin{array}{l}-0.12 \\
(0.18)\end{array}$ & $\begin{array}{l}-0.54 \\
(0.42)\end{array}$ & $\begin{array}{l}0.0021 \\
(0.29)\end{array}$ \\
\hline Hearing 1 & $\begin{array}{l}0.59 \\
(1.69)\end{array}$ & $\begin{array}{l}2.50 \\
(3.18)\end{array}$ & $\begin{array}{l}-3.84 \\
(3.65)\end{array}$ \\
\hline Hearing 2 & $\begin{array}{l}0.88 \\
(1.97)\end{array}$ & $\begin{array}{l}3.80 \\
(3.65)\end{array}$ & $\begin{array}{l}0.42 \\
(3.90)\end{array}$ \\
\hline $\begin{array}{l}\text { Log Urban } \\
\text { Population }\end{array}$ & $\begin{array}{l}-1.29 \\
(1.03)\end{array}$ & $\begin{array}{l}-2.79 \\
(2.06)\end{array}$ & $\begin{array}{l}-2.45 \\
(1.87)\end{array}$ \\
\hline $\begin{array}{l}\text { Log Median } \\
\text { Family Income }\end{array}$ & $\begin{array}{l}-1.73 \\
(2.45)\end{array}$ & $\begin{array}{l}-4.88 \\
(4.35)\end{array}$ & $\begin{array}{l}0.39 \\
(5.01)\end{array}$ \\
\hline $\begin{array}{l}\text { Log Black } \\
\text { Population }\end{array}$ & $\begin{array}{l}0.13 \\
(0.40)\end{array}$ & $\begin{array}{l}0.37 \\
(0.76)\end{array}$ & $\begin{array}{l}0.41 \\
(0.73)\end{array}$ \\
\hline Constant & $\begin{array}{l}32.0 \\
(23.40)\end{array}$ & $\begin{array}{l}85.2 * \\
(46.59)\end{array}$ & $\begin{array}{l}19.8 \\
(42.98)\end{array}$ \\
\hline $\begin{array}{l}\text { Log Alpha } \\
\text { Constant }\end{array}$ & $\begin{array}{l}2.34 * * * \\
(0.27)\end{array}$ & $\begin{array}{l}3.47 * * * \\
(0.23)\end{array}$ & $\begin{array}{l}2.91 * * * \\
(0.46)\end{array}$ \\
\hline $\begin{array}{l}\mathrm{N} \\
\text { Pseudo R-squared }\end{array}$ & $\begin{array}{l}134 \\
0.07\end{array}$ & $\begin{array}{l}134 \\
0.02\end{array}$ & $\begin{array}{l}134 \\
0.11\end{array}$ \\
\hline
\end{tabular}


Note: Variance exceeds the mean indicating negative binomial regression is appropriate. Standard errors in parentheses. $* \mathrm{p}<0.05, * * \mathrm{p}<0.01, * * * \mathrm{p}<0.001$

Table 2.5: Additional Negative Binomial Models of SET Commission with Interaction Term

\begin{tabular}{llll}
\hline & $\begin{array}{l}\text { Number Times } \\
\text { Testifying }\end{array}$ & $\begin{array}{l}\text { Number of } \\
\text { Words }\end{array}$ & $\begin{array}{l}\text { Number of } \\
\text { Questions }\end{array}$ \\
\hline Congresswoman & $\begin{array}{l}4.52^{* *} \\
(1.92)\end{array}$ & $\begin{array}{l}7.62^{*} \\
(3.57)\end{array}$ & $\begin{array}{l}3.09 \\
(3.14)\end{array}$ \\
Party Identification & 0.60 & 1.10 & 2.13 \\
& $(0.87)$ & $(1.61)$ & $(1.76)$ \\
Congresswoman X & -1.63 & -2.89 & 1.04 \\
Party Identification & $(2.05)$ & $(3.93)$ & $(4.13)$ \\
\hline N & 134 & 134 & 134 \\
Pseudo R-squared & 0.07 & 0.02 & 0.11 \\
\hline
\end{tabular}

Note: Variance exceeds the mean indicating negative binomial regression is appropriate. Standard errors in parentheses. ${ }^{*} \mathrm{p}<0.05,{ }^{*} \mathrm{p}<0.01,{ }^{* * *} \mathrm{p}<0.001$. Full estimates are provided in Table A2.4 of the Appendix.

Table 2.6: Additional Negative Binomial Models of SET Commission with Interaction Dummy Terms

\begin{tabular}{llll}
\hline & $\begin{array}{l}\text { Number Times } \\
\text { Testifying }\end{array}$ & $\begin{array}{l}\text { Number of } \\
\text { Words }\end{array}$ & $\begin{array}{l}\text { Number of } \\
\text { Questions }\end{array}$ \\
\hline Female Democrat & $\begin{array}{l}2.89^{*} \\
(1.57)\end{array}$ & $\begin{array}{l}4.72 \\
(3.55)\end{array}$ & $\begin{array}{l}4.12 \\
(3.27)\end{array}$ \\
Female Republican & $3.92^{*}$ & $6.51^{*}$ & 0.96 \\
& $(2.06)$ & $(3.75)$ & $(3.47)$ \\
Male Republican & -0.60 & -1.10 & -2.13 \\
& $(0.87)$ & $(1.61)$ & $(1.76)$ \\
\hline N & 134 & 134 & 134 \\
Pseudo R-squared & 0.07 & 0.02 & 0.11 \\
\hline
\end{tabular}

Note: Variance exceeds the mean indicating negative binomial regression is appropriate. Standard errors in parentheses. ${ }^{*} \mathrm{p}<0.05,{ }^{* *} \mathrm{p}<0.01,{ }^{* * *} \mathrm{p}<0.001$. Full estimates are provided in Table A2.5 of the Appendix. 
Figure 2.4:

Figure 4. Predicted Number of Times Speaking during SET Hearings

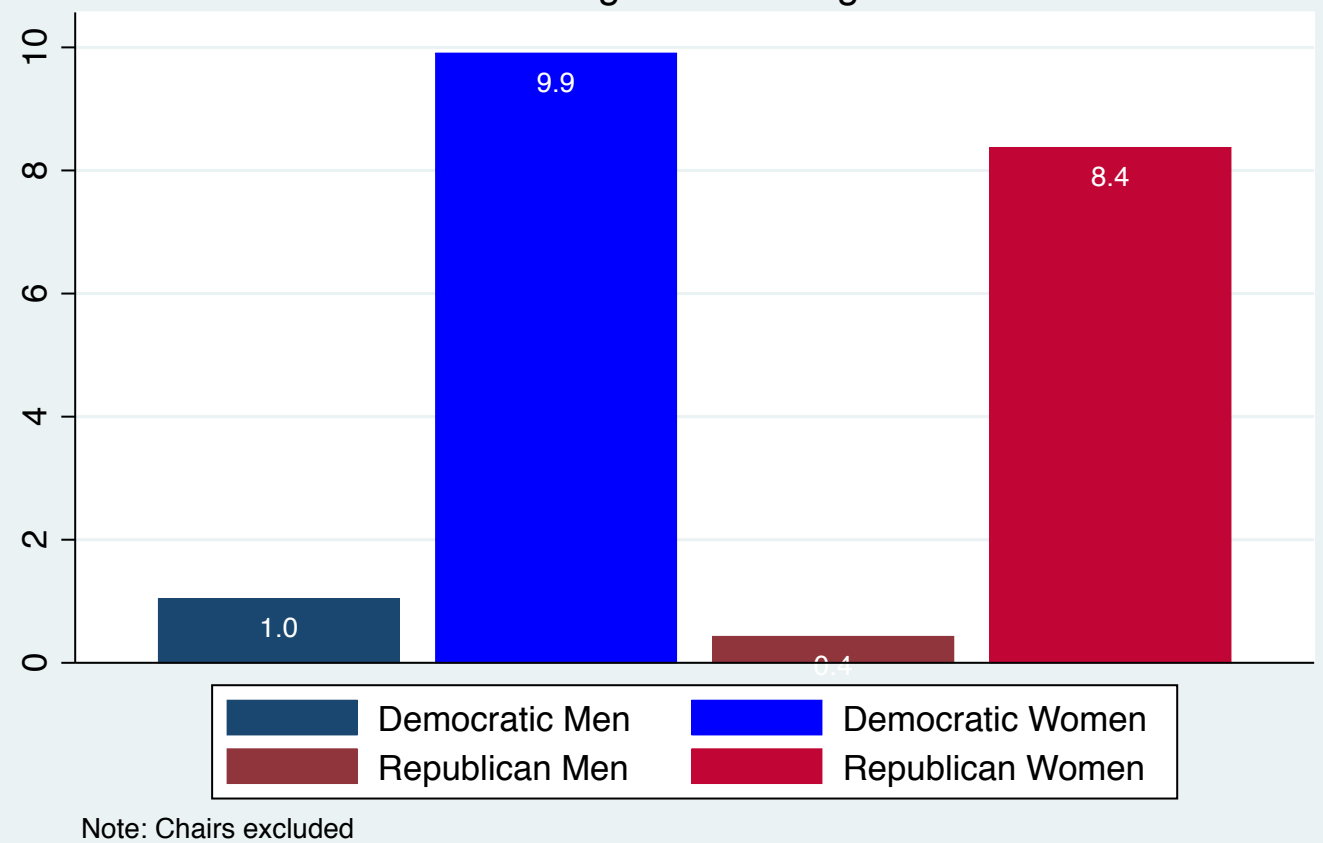

Figure 2.4a:

Figure 4a. Predicted Number of Times Speaking during SET Hearings

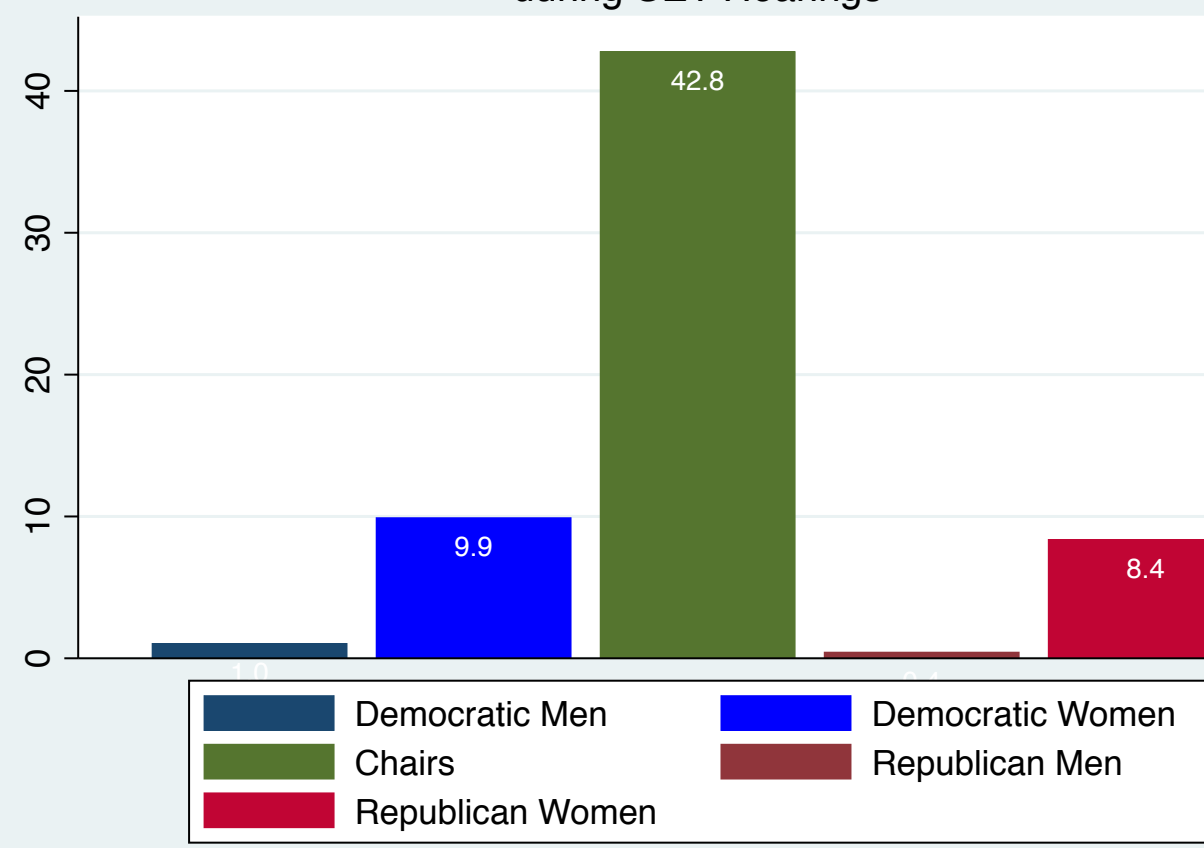


Figure 2.5:

Figure 5. Predicted Number of Words during SET Hearings

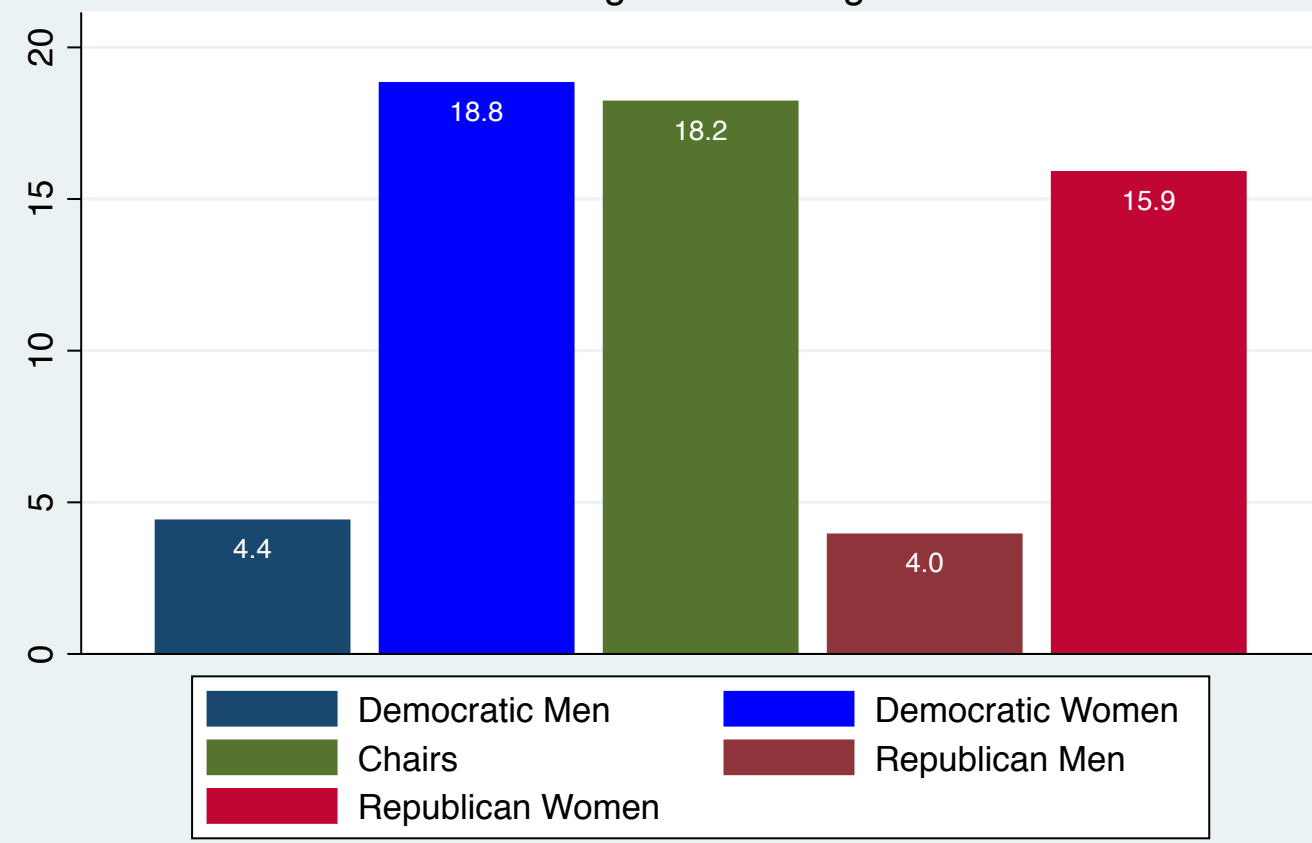

Figure 2.6:

Figure 6. Predicted Number of Questions during SET Hearings

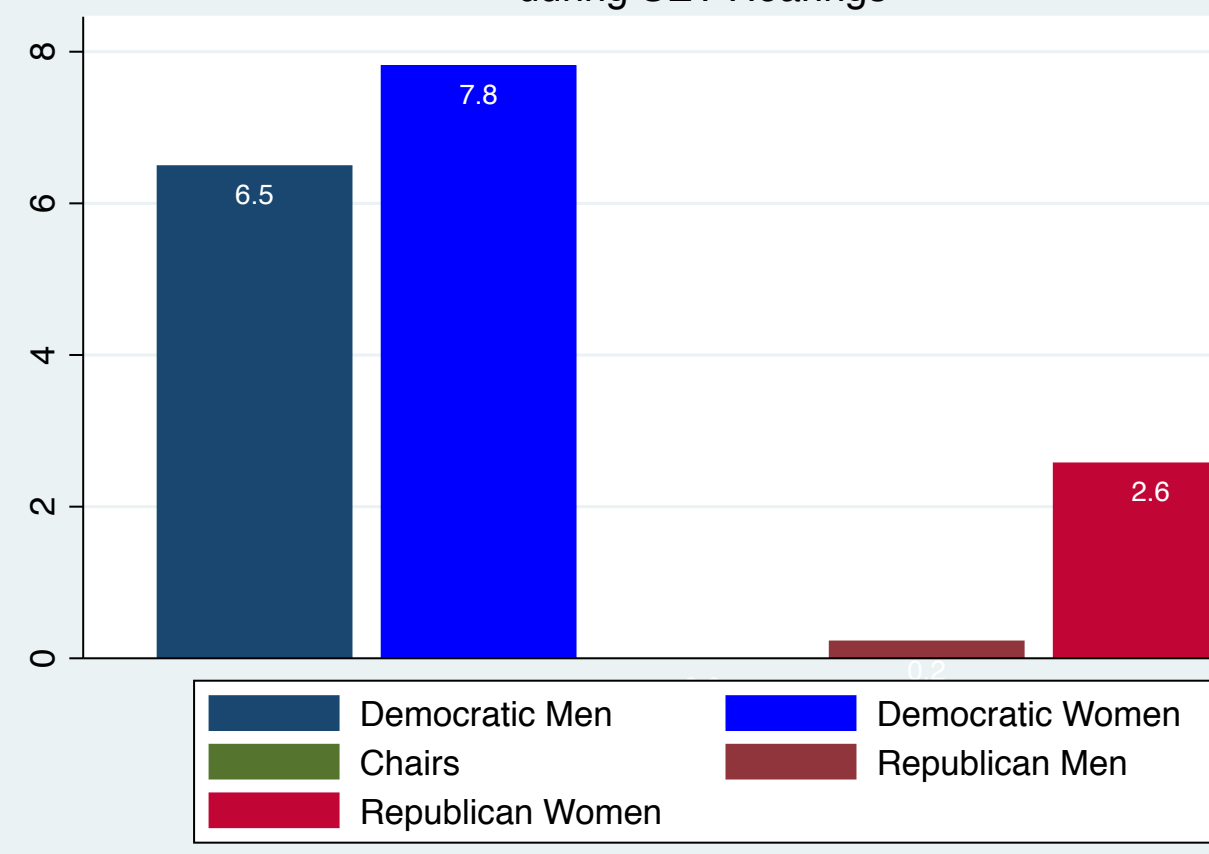


Table 2.7: OLS Models of Legislative Entrepreneurship in the U.S. House, $94^{\text {th }}-103^{\text {rd }}$ Congresses

Majority Party

Member

Congresswoman $\mathbf{X}$

Majority Party Member

Distance from

Chamber Median

Distance from

Majority Party Median

Chair

Seniority

Constant

R-Squared

F-Statistic
(1)

$\begin{array}{ll}12.1^{* * *} & 10.5 * * * \\ (2.53) & (2.53)\end{array}$

$15.7 * * *$

4.14*

(1.66)

(2.36)

(2)

(3)

$16.9 * * *$

(4.19)

$16.4 * * *$

(1.72)

$-7.45$

(5.25)

$9.54 * *$

(3.99)

(4.03)

$-19.4 * * *$

(4.16)

$\begin{array}{ll}18.1^{* * *} & 17.8 * * * \\ (2.96) & (2.95)\end{array}$

$1.36 * * *$

(0.18)

$1.38^{* * *}$
$(0.18)$

$56.3^{* * *}$

(3.43)
(4)

$12.8^{* *}$

4.49*

(2.41)

$-3.64$

(5.23)

$\begin{array}{llll}39.4 * * * & 56.3^{* * *} & 38.9^{* * *} & 56.0^{* * *} \\ (2.81) & (3.43) & (2.83) & (3.45)\end{array}$

NOTES: Standard errors are in parentheses. ${ }^{*} \mathrm{p}<0.05, * * \mathrm{p}<0.01, * * * \mathrm{p}<0.001$. The models also incorporated independent variables measuring status in minority groups, status on prestigious, policy, and distributive committees, dummy variables controlling for session, and so on. Full estimates are provided in Tables A2.6 \& A2.7 of the Appendix.

Table 2.8: Coefficients for Women in OLS Models of Legislative Entrepreneurship per Congressional Session, $94^{\text {th }}-103^{\text {rd }}$

Congress Coefficient (Standard Error) for Congresswomen

94th $\quad-1.03(3.78)$

95th

$3.11(5.55)$ 
96th

97th

98th

99th

100th

$101 \mathrm{st}$

102nd

103rd
$4.27(7.67)$

$3.20(9.53)$

$16.4 *(8.44)$

$19.8 *(9.52)$

$9.86(8.98)$

$11.1(8.68)$

$24.8 * *(9.18)$

$12.6^{*}(5.81)$

NOTES: Each congressional session represents a separate OLS model. Standard errors are in parentheses. ${ }^{*} \mathrm{p}<0.05, * * \mathrm{p}<0.01, * * * \mathrm{p}<0.001$. Full estimates are provided in Table A2.8 Appendix.

Table 2.9: Comparing Legislative Entrepreneurship of Female Democrats and Republicans

\section{Variable}

Female Democrat $\quad 7.57^{* *}$

Female Republican $\quad 13.4^{* *}$

Male Republican $\quad-1.46$

(2.46)

NOTES: Standard errors in parentheses. ${ }^{*} \mathrm{p}<0.05, * * \mathrm{p}<0.01, * * * \mathrm{p}<0.001$. Full estimates are provided in Table A2.9 Appendix. 
Figure 2.7:

\section{Predicted Legislative Entrepreneurship Scores by Party and Gender}

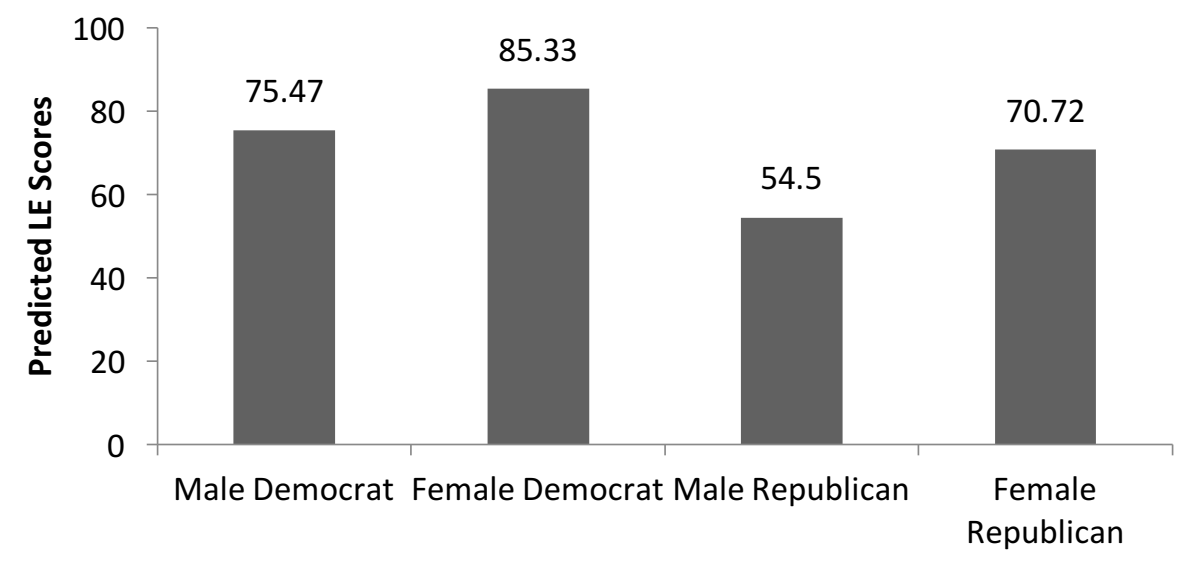

NOTE: The predicted values are based on typical male and female members. The mean entrepreneurship score during this time period was 61; Min: 0; Max: 494.5; Std. Dev.: 41.4 


\section{Chapter 3: \\ How the Women of Congress Handle Oversight of Women's Issues}

The preceding chapter established that when women are elected, they represent women's interests, as well as make a difference in the overall effectiveness and productivity of the institution. In House hearings for the Family and Medical Leave Act and for the Commission on the Advancement of Women and Minorities in Science, Engineering, and Technology Development Act, women participated more overall than their male counterparts. The analysis showed that women have been successful in attaining the goal that many of them express having: representing women as a distinct constituency (i.e. Carroll 2002; Reingold 1992, 2000; Rosenthal 1998; Thomas 1994, 1997). Without women in Congress, issues related to family leave and women in STEM may not have been introduced onto the policy agenda. In this chapter, I again turn to hearings---this time oversight hearings related to women's issues. Do committees with more women members hold more hearings related to women's issues?

\section{How does a member's gender play a role in oversight of women's issues?}

Women have not had many opportunities to hold positions of leadership ${ }^{27}$. The U.S. has not elected a female President or Vice President, has not given the position of majority or minority leader to a woman in the Senate, and has had only one female Speaker of the House. How else can women be effective when they are serving in Congress if they do not have access to the highest institutional leadership positions? I believe that women are better able to assert themselves within the committee structure, as I found in the previous chapter, and more specifically for this chapter, when committees are handling the oversight of women's issues.

\footnotetext{
${ }^{27} \mathrm{http}$ //history.house.gov/Exhibitions-and-Publications/WIC/Historical-Data/Women-Elected-to-PartyLeadership/
} 
The growth of women in Congress has increased steadily since the 1992 "Year of the Woman," when a record number of women were elected to the Senate. Increased party competition coupled with ideological polarization has seen a difference in the number of women elected from each party. To revisit Figure 1.1, it is clear that before 1992, female Democrats and Republicans were elected at about the same rate. Since then, Democratic women have outpaced Republican women in attaining congressional seats. Democrats prioritize the recruitment of women to run for office, while Republican ideology tends to limit the involvement of women. As social conservatives are a key group within the party, traditional gender roles tend to be emphasized, thus limiting the pool of women from which to draw. Due to such a stark underrepresentation of Republican women in recent years, as well as the general underrepresentation of women within the House and Senate, it is difficult empirically to assess congresswomen in general, or to draw meaningful conclusions about Republican women in particular. However, over an extended period like the one presented in this chapter (1947-2008), and by examining committee membership rather than the behavior of individual legislators, I will be able to observe women's additive influence on oversight---an important step in the policymaking process that has been overlooked by previous studies of women in Congress.

Past research shows that having women present in Congress does make a difference in the legislative agenda (e.g., Swers 2002a; 2013), and that congresswomen use their committee positions to advocate for the incorporation of women's interests into committee legislation (Dodson 1998, 2002; Dodson et al.1995; Gertzog 1995; Norton 2002; Swers 2002b). Additionally, there is much evidence that women use the committee positions they are dealt in order to effect change and represent the needs of their female constituents, or simply of women in general. During the 1990s, moderate Republican and Democratic women worked together to bridge the gap 
between their parties. During the welfare reform debate in 1994, "Republican women who held seats on the committee of jurisdiction, the Ways and Means Committee, convinced their male Republican colleagues to incorporate child-support enforcement and greater funding for childcare in the bill" (Swers 2016b). In more current times, when issues do not fall neatly along partisan lines, women in the Senate work together to compromise.

For example, Democratic and Republican women in the Senate have aggressively pursued reforms to the military justice system to address the problem of sexual assault in the military. Pentagon surveys indicate that the incidence of sexual assault in the military increased 35 percent between 2010 and 2012. Moreover, only a small percentage of victims file a report and very few perpetrators are prosecuted. Incensed by the ongoing problem of sexual assault and the military's inability to address it, the women in the Senate sought to draw more attention to the issue and began crafting policy solutions. Because seven women, two Republicans and five Democrats, served on the Armed Services Committee, they were able to convince the Committee chair to call a rare hearing with the chair of the Joint Chiefs of Staff and all the uniformed chiefs of the armed services in order to confront each of them about the issue and what could be done to improve the military's response. The female senators then worked together to craft reforms, several of which Congress ultimately adopted, including changing the procedures used to prosecute sexual assault, eliminating the ability of military commanders to overturn jury convictions, and providing services and legal counsel to victims. ${ }^{28}$

However, only since the 1990s have enough women been elected, gaining party and institutional seniority, and thus gaining committee leadership positions or prestigious committee membership. Again, by instituting a longitudinal design, I hope to observe a general trend in women's influence.

Not only do women differentiate themselves from their male colleagues in their advocacy for issues that directly affect women in the electorate, but also, they are more effective legislators, where effectiveness is defined as "the advancement of a member's agenda items through the legislative process and into law" (Volden, Wiseman, and Wittmer 2013; 327). It has been argued

${ }^{28}$ Quoted from Swers 2016b. 
that women are more effective partially due to their deep advocacy for women's issues, but also for their unique consensus-building traits, such as being collaborative and consensual (e.g., DuerstLahti 2002a \& 2002b; Kathlene 1995). Women are also effective due to their exceptional quality, especially when we consider the tough electoral environments they have to endure (e.g., Jenkins 2007; Lawless and Pearson 2008; Milyo and Schosberg 2000; Sanbonmatsu 2006). Therefore, if women are strong advocates for women's issues, and if women are more effective and entrepreneurial, even when they are underrepresented, and even when they are in the minority party (e.g., Volden, Wiseman, and Wittmer 2013), then I expect women to be a crucial force in getting committees to hold oversight hearings considering issues that directly affect women.

This chapter examines whether the number of women on a committee affects the amount of oversight conducted on women's issues. I predict that the more women on a committee, the more likely it is that that committee will hold oversight hearings considering women's issues. By investigating committee behavior, I am able to get closer to the policymaking process than previous scholars who were concerned with congresswomen's agenda setting behavior. If the presence of female members on a committee affects the volume of oversight on women's issues, then electing women makes a clear difference in House deliberations as well as public policy.

\section{How do congresswomen affect the oversight process?}

From the brief discussion above, as well as from the findings of the previous chapter, it is clear that electing women to Congress affects the policy that is made, but it also affects the male dominated institution. When we consider the fact that electing women produces different voices at the table and a different way of legislating, then it is important to consider the various activities that both congresswomen and congressmen engage in. Although the total number of days spent on hearings and meetings in the House have declined over time, the number of oversight days has 
increased (Aberbach 2002). Oversight is an important activity to research for a couple of reasons. One, it is an activity that is proximate to the policymaking process: most laws are eventually evaluated, whether proactively or reactively (police patrols versus fire alarms a la McCubbins and Schwartz 1984). If members are going to engage in oversight, it is worth capitalizing on the activity. This brings me to my second reason for investigating oversight: members can easily use the activity to claim credit. In the same way, a member can point to creating legislation for constituents, they can also point to keeping a watchful eye on public policy and the bureaucracy.

Therefore, oversight is an interesting area to research. It is an important activity to members of Congress because it is a unique opportunity for legislators to participate in policy change outside of legislative hearings. Oversight is also important to study because it more proximate to the policymaking process than previous studies on women in Congress. However, why would we expect women to engage in more oversight than men? I propose that women, due to their interest in directly representing women, as well as their personal and gendered characteristics of being generally more effective than men, will cause the committees they serve on to hold more oversight hearings considering women's issues: the more women serving on the committee, the more oversight hearings held considering women's issues.

When it comes to actively working on legislation in committees, women participate differently than their male colleagues. At the state level, women in the Colorado legislature entered the committee hearing debates later, spoke less often than their male colleagues did, and interrupted witnesses less frequently than male legislators did (Kathlene 1994). The findings also suggest that as the number of women serving in a legislative body increases, male members become more verbally aggressive and controlling of hearings (Kathlene 1994). This obviously puts women at a disadvantage in their goal of creating good public policy (e.g., Hall 1996). 
However, other findings at the state and national level show that female representatives are able to actively advocate for female constituents by fighting to incorporate more women's interests into committee legislation (Dodson 1998, 2002; Dodson et al. 1995; Gertzog 1995; Norton 2002; Swers 2001, 2002). Also, female committee chairs in state legislatures have reported a more integrative leadership style than their male counterparts, by sharing power with others, collaborating with other chairs, and by sharing strategic information with committee members (Rosenthal 1997, 1998, 2000). Plus, women are less likely than men to say they care about achieving powerful positions; rather, they want to move up the ladder, pull people together, build issue coalitions, and develop creative approaches to solving policy problems (Rosenthal 1997). This means than when we elect women, we get different results---a different type of legislator--than when we elect men.

Behavioral differences between men and women are explanatory on their own, but considering other factors like the electoral environment women face, can be helpful, too. "Given that women tend to face more electoral competitors (Lawless and Pearson 2008) and higher-quality challengers (Milyo and Schosberg 2000), while receiving less support from party organizations (Sanbonmatsu 2006), and needing to work harder to secure campaign funds (Jenkins 2007), it may be the case that those female candidates who succeed in being elected are of exceptionally high quality (and higher quality than the average male candidate)" (Volden, Wiseman, and Wittmer 2013; 327). Therefore, because women are more collaborative, consensual, and highly qualified, they are more effective and entrepreneurial, and I predict due to these characteristics they will spur the committees they serve on to hold more oversight hearings on women's issues.

\section{Expectations}


If women hold characteristics that make them more entrepreneurial as well as more effective when they are in the minority (and sometimes when they are in the majority) (e.g., Volden, Wiseman, and Wittmer 2013), and minority party women are able to work on a more encompassing set of women's issues, including more feminist issues than just general welfare issues (e.g., Swers 2002a), we know women have a good legislative strategy that accounts for institutional norms. They know when and how to act in order to get the legislation they care about passed. In short, their characteristics make them exemplary entrepreneurs. Taking into consideration these shared characteristics as well as underrepresentation in a male dominated institution, as well as their propensity to not care as much about power compared to men, I think women will use the positions that are available to them in order to see their policy preferences and general legislative goals met.

Women cooperate more, are better quality, and are more effective than their male counterparts, so even though they are not in traditionally powerful leadership positions, they will still be able to perform oversight on issues they care deeply about---issues that affect women directly. This means that in the area of oversight on women's issues, the more women on a committee, the more likely that committee is to hold oversight hearings on women's issues. I believe I will observe these effects not only based on the previous literature and the previous chapter's findings on entrepreneurship, but also due to the previous chapter's findings on hearings considering the FMLA and SET commission. Women participated in these hearings more so than their male counterparts, disregarding party and disregarding salience. Women worked to pass these bills through committee with their participation. These findings not only bolster previous interview-based literature where women expressed their duty to represent female constituents, but also help me predict women's activity on oversight. If women are exemplary entrepreneurs, 
navigating a male dominated institution, as well as partisan politics, then I believe women will use oversight hearings as yet another venue in which to represent the unique needs of female citizens.

\section{Data and Methods}

DEPENDENT VARIABLES ${ }^{29}$. The main dependent variable of interest is the number of oversight hearings considering women's issues per committee per congressional session, during the $80^{\text {th }}-110^{\text {th }}$ congresses. Therefore, the unit of analysis is the congressional session/ committee pair. I employ the same coding criteria for oversight hearings as McGrath (2013) and MacDonald and McGrath (2016). I used STATA syntax to identify key words ${ }^{30}$ in the hearings' description variable within the dataset to code whether the hearings were oversight or not. The other dependent variable, used for comparison purposes, is a count of legislative hearings considering women's issues per committee per congressional session. It was constructed from the "referral" variable in the congressional hearings dataset, available from the Policy Agendas Project ${ }^{31}$. In an older version of the codebook, the variable is defined as coding "whether the hearing was a legislative or nonlegislative hearing." The older definition and current definition ${ }^{32}$ describe basically the same concept, and the other variables in the dataset have been consistent over time, thus, I believe what I am defining here as "legislative" hearings is valid. The time period that I use in this analysis is simply due to the data available from the Policy Agendas Project on congressional hearings,

\footnotetext{
${ }^{29}$ Data sources, definitions, and descriptive statistics for Chapter 3 can be found in Table A3.1 of the Appendix.

${ }^{30}$ Examples: oversight, review, report, budget, bureau, department, president, etc.

31 "The data used here were originally collected by Frank R. Baumgartner and Bryan D. Jones, with the support of National Science Foundation grant numbers SBR 9320922 and 0111611, and were distributed through the Department of Government at the University of Texas at Austin. Neither NSF nor the original collectors of the data bear any responsibility for the analysis reported here."

${ }^{32}$ In the most current version of the congressional hearings codebook, it is defined as: This column records whether the hearing was a "referral hearing": $0=$ No mention of a bill number or name, or hearings on draft legislation (such as appropriations bills or defense and intelligence authorization bills). $1=$ Mentions a bill number or name (as in, "a hearing to consider S 2137, the...") consistent with language in Talbert et al. (1995) and Baumgartner et al. (2000).
} 
although it is a satisfactory comprehensive time period: 1947-2008. Figure 3.1 charts a comparison of the women's issue hearings, plotting the number of oversight and legislative hearings over time. The general trend is that the number of legislative hearings has decreased, while the number of oversight hearings has increased. This is part of the reason why I predict women will help spur oversight of women's issues: as more women are elected to Congress and as more oversight occurs, women will spur oversight of issues particularly related to the needs of women constituents. Women will take advantage of the changing institutional norms to represent women.

In order to code the hearings as women's issues, I coded the hearings' descriptions for whether or not they covered women's issues. I did this with key word coding ${ }^{33}$, utilizing the same method as I did for the oversight dependent variable. I used STATA syntax to locate hearings with the key words in the description variable provided in the dataset. In order to capture as many hearings concerning women's issues as possible, I included every term I could think of that is explicitly, yet uniquely related to women and girls. I based the rest of my coding of women's issues on Swers $(2002 ; 34-35)$, where she uses the websites of different women's organizations ${ }^{34}$ to determine what kinds of policy issues are of interest to those organizations, and thus would be considered women's issues. She includes issues listed by non-partisan groups, as well as liberal and conservative groups. I included key terms based on the policy areas listed as major concerns to those groups on their websites. Once all of the hearings were coded as women's issue hearings or not, I was able to code them as oversight or legislative hearings, and finally sum the number of women's issue oversight and women's issue legislative hearings per committee per congressional session.

\footnotetext{
${ }^{33}$ Key terms included: women, girls, mammography, pregnancy, abortion, etc.

${ }^{34}$ See Appendix Table A4.2.
} 
INDEPENDENT VARIABLES. The main independent variable of interest is the proportion of women on each committee, during each session of Congress from the $80^{\text {th }}$ through the $110^{\text {th }} . I$ included a time trend variable to control for the tendency of oversight to increase over time, where the $80^{\text {th }}$ Congress equals " 0 ", $81^{\text {st }}$ Congress equals " 1 " $\ldots$ and $110^{\text {th }}$ Congress equals " 30 ". The Democratic majority variable controls for the sessions in which the Democrats held a majority, where the variable equals " 1 " when Democrats held a majority in the House, "0" when they did not. The Democratic president variable controls for having a Democratic president and any effects that such a president might have on the congressional-executive dynamic. This equal " 1 " when there was a Democratic president, "0" when there was not. The public mood variable (Ellis and Stimson 2012) places opinion on a liberal-conservative continuum, where more liberal mood is coded with larger numbers and more conservative mood is coded with smaller numbers. Finally, I included committee specific fixed effects. These dummy variables equal 1 if the committee is the committee in question, 0 if it is not. Ways and Means was omitted as the reference category.

\section{Findings}

I present the results of the analysis in Table $3.1^{35}$, where both models use OLS regression. In model 1, the dependent variable is the count of women's issue oversight hearings per committee per congressional session. In this model, the more women on the committee, or the larger the proportion of women on the committee, the more oversight that committee will engage in. The coefficient for the proportion of women reaches the highest level of statistical significance, indicating that we can expect this result to hold much more often than not. This means that my predictions are supported: the presence of women is associated with the committees they serve on engaging in more oversight of women's issues. Not only this, but I observe that having more

\footnotetext{
${ }^{35}$ Although there are many zero observations for the number of women in committees, the OLS and Negative Binomial regression models produce the same results. I have chosen to present the OLS results.
} 
women on a committee makes the committee more likely to hold about 1 more oversight hearing on women's issues than committees with fewer female members. Therefore, although the magnitude of the coefficient is small, the overall finding bolsters the literature linking substantive (policy that is produced) and descriptive (who makes the policy) representation. Also, we can conclude that women, being consensus builders and high quality legislators, are not only effective at getting bills through the legislative process, they are also effective at conducting oversight on issues that are particularly important to women.

In model 2, the dependent variable is the number of legislative hearings considering women's issues per committee per congressional session. There is a negative coefficient for the proportion of women on a committee, which implies that the more women on a committee, the less legislative hearings that committee will hold. However, the coefficient for the proportion of women does not reach statistical significance, so I cannot comment on any substantive implications this has. The fact that the committees they are members of conduct more oversight makes sense, then: women need to represent the needs of their female constituents, and if they aren't able to spur productivity on legislative hearings, than they choose to initiate oversight hearings. I think that considering the other findings I have previously discussed concerning women as more effective and entrepreneurial legislators, coupled with the current findings, I believe we can conclude that women are adaptable to the institutional constraints of their environment.

I included the specific committees as controls since certain committees may have the propensity to be more productive than others. Also, Swers (2002) identifies certain committees as women's issue committees: Education, Commerce, and Judiciary. This means that these committees see legislation regarding women's issues more often than other committees. When we examine the Committee on Education, it holds less oversight hearings on women's issues the more 
women are present, but more legislative hearings on women's issues. Both of these coefficients reach statistical significance. However, Commerce and Judiciary do not hold similar trends. Instead, both committees hold more legislative hearings the more women are present at a statistically significant level. Although there is not a clear connection to be made between women's membership on committees that are more likely to consider women's issues and oversight hearings, there is a general connection between these types of committees and legislative hearings. This is a positive finding: when more women get a seat on women's issue committees, they help spur those committees to hold legislative hearings considering women's issues. Party leaders may place women on those committees for this precise reason---having women present during the debate over agenda items that can specifically affect women makes good public policy and good politics.

In Table 3.2 (full estimates provided in Table A3.2 of the Appendix), I present two additional models to show that there is not much difference between using the proportion of women variable and the number of women variable, other than the way the coefficient is interpreted. Models 1 and 2 use the count of women's issue oversight hearings as the dependent variable and models 3 and 4 use the count of women's issue legislative hearings. Consistent with the results I have already discussed, you can see that the number and proportion of women on committees holding oversight hearings on women's issues have positive and statistically significant coefficients. Both models clearly indicate that having more women present on a committee leads to more oversight on women's issues. Therefore, although women are underrepresented in the House, and although they do not hold many party or institutional potions of leadership, women are able to make an important impact in committees. These results bolster the research that finds a connection between substantive and descriptive representation, where the former enhances the latter. 


\section{Conclusions}

Considering the findings of the previous chapter, I believe we now have enough evidence to suggest that women's behavior not only enhances substantive representation of women's issues (thus benefitting the female citizenry), but also enhances the productivity within Congress. The previous chapter's findings regarding entrepreneurship displays additional findings suggesting that electing more women to Congress makes the institution more productive in fostering women's interests. Plus, by having women at the table, Congress is able to produce legislation like the FMLA and SET commission, taking policies from the government agenda, getting them on the floor for a vote, thus moving them to the decision agenda. The results from the current chapter and the previous chapter show us that women are effective even though they do not hold as many leadership positions as men, and are entrepreneurial even in their current state of underrepresentation.

In light of the findings presented in this chapter, I conclude that women are able to attain their goal of representing women: the descriptive representatives are able to substantively represent their female constituents. Not only are congresswomen able to inspire their committees to hold oversight hearings concerning women's issues, but the more women who serve on the committees, the more oversight hearings they hold. These findings lend legitimacy to previous findings that women are more effective than men at achieving legislative goals. They are able to substantially make a difference in the oversight process by taking the institutional hand they are dealt and playing it to their advantage. Therefore, electing women to Congress is making a difference, both in the policies that are produced and in shaking up the male dominated institutional norms. Plus, Congress as a whole benefits from women being present, and so does our democracy: the concerns of female citizens are heard at the same time the institution becomes more productive. 


\section{Chapter 3 Tables and Figures}

Figure 3.1:

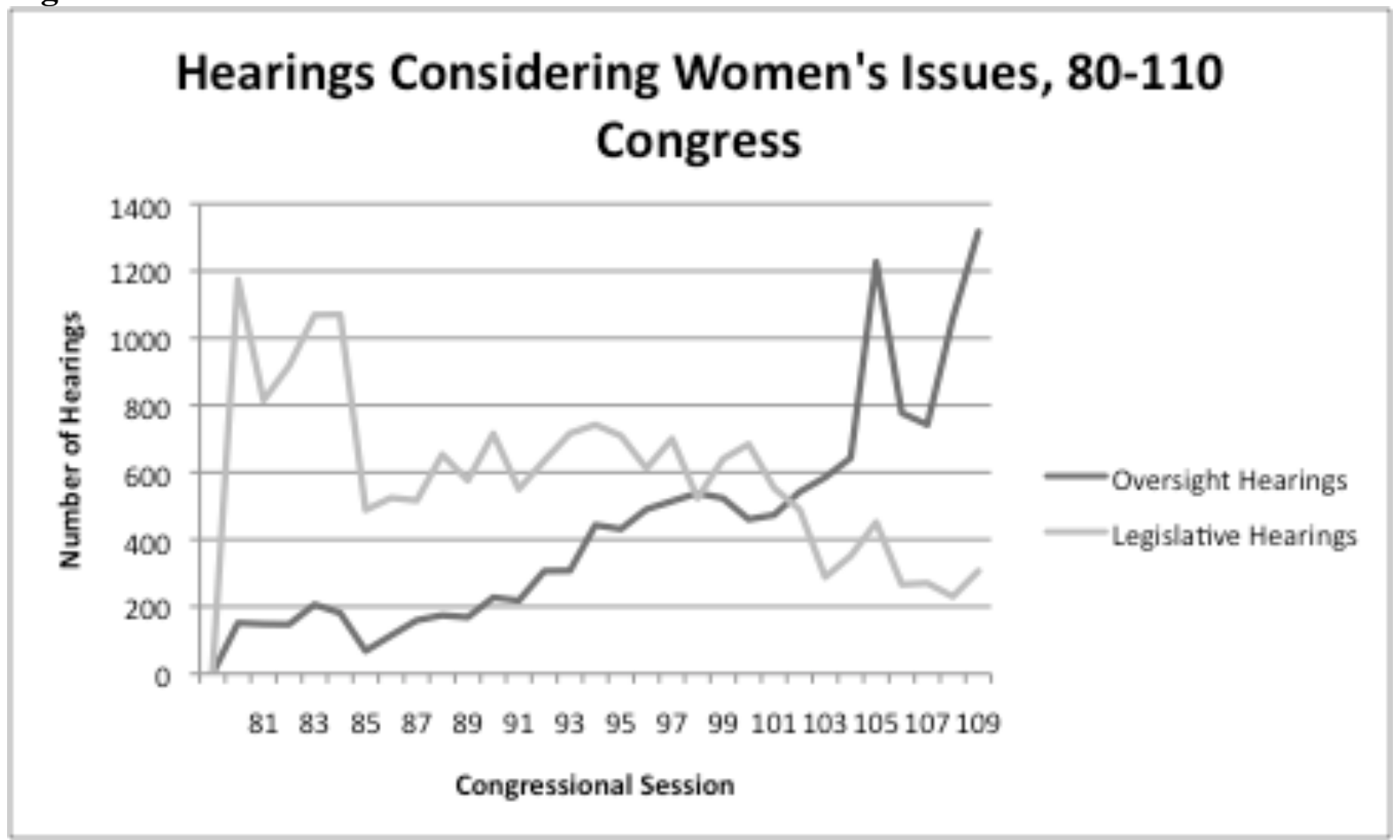

Table 3.1: Comparison of OLS Models Considering the Number of Women's Issue Hearings, Oversight versus Legislative, $80^{\text {th }}-110^{\text {th }}$ Congress http://swampland.time.com/2013/10/16/women-are-the-only-adults-left-in-washington/

\begin{tabular}{lll}
\hline & $\begin{array}{l}\text { Number Oversight } \\
\text { Hearings }\end{array}$ & $\begin{array}{l}\text { Number Legislative } \\
\text { Hearings }\end{array}$ \\
\hline $\begin{array}{lll}\text { Proportion } \\
\text { Women }\end{array}$ & $\begin{array}{l}1.10^{* * *} \\
(0.26)\end{array}$ & -0.050 \\
& $(0.38)$ \\
Time & $1.36^{* * *}$ & $-1.15^{* * *}$ \\
& $(0.17)$ & $(0.24)$ \\
Democrat & $-5.43^{*}$ & -0.87 \\
Majority & $(2.68)$ & $(3.91)$ \\
& 0.95 & -4.86 \\
Democrat & $(2.09)$ & $(3.05)$ \\
Presidency & $-14.4^{* *}$ & 7.54 \\
Agriculture & $(5.16)$ & $(7.51)$ \\
& $73.3^{* * *}$ & -3.12
\end{tabular}


(5.17)

(7.54)

\begin{tabular}{|c|c|c|}
\hline Armed Services & $\begin{array}{l}-4.28 \\
(5.22)\end{array}$ & $\begin{array}{l}19.8^{* *} \\
(7.61)\end{array}$ \\
\hline Banking & $\begin{array}{l}-9.58^{*} \\
(5.27)\end{array}$ & $\begin{array}{l}4.79 \\
(7.68)\end{array}$ \\
\hline Budget & $\begin{array}{l}-21.1 * * * \\
(5.98)\end{array}$ & $\begin{array}{l}-18.3^{*} \\
(8.72)\end{array}$ \\
\hline $\mathrm{DC}$ & $\begin{array}{l}-19.1 * * * \\
(5.63)\end{array}$ & $\begin{array}{l}-8.75 \\
(8.20)\end{array}$ \\
\hline Education & $\begin{array}{l}-9.46^{*} \\
(5.22)\end{array}$ & $\begin{array}{l}17.2^{*} \\
(7.61)\end{array}$ \\
\hline $\begin{array}{l}\text { Government } \\
\text { Operations }\end{array}$ & $\begin{array}{l}19.2 * * * \\
(5.20)\end{array}$ & $\begin{array}{l}-3.32 \\
(7.58)\end{array}$ \\
\hline Commerce & $\begin{array}{l}-0.55 \\
(5.18)\end{array}$ & $\begin{array}{l}34.5 * * * \\
(7.55)\end{array}$ \\
\hline Foreign Affairs & $\begin{array}{l}3.58 \\
(5.18)\end{array}$ & $\begin{array}{l}5.24 \\
(7.55)\end{array}$ \\
\hline $\begin{array}{l}\text { House } \\
\text { Administration }\end{array}$ & $\begin{array}{l}-26.2 * * * \\
(5.32)\end{array}$ & $\begin{array}{l}-20.2 * * \\
(7.76)\end{array}$ \\
\hline Interior & $\begin{array}{l}-10.7^{*} \\
(5.17)\end{array}$ & $\begin{array}{l}53.9 * * * \\
(7.53)\end{array}$ \\
\hline Judiciary & $\begin{array}{l}3.60 \\
(5.18)\end{array}$ & $\begin{array}{l}53.4 * * * \\
(7.55)\end{array}$ \\
\hline $\begin{array}{l}\text { Merchant } \\
\text { Marine }\end{array}$ & $\begin{array}{l}-13.1^{* *} \\
(5.61)\end{array}$ & $\begin{array}{l}8.01 \\
(8.18)\end{array}$ \\
\hline Post Office & $\begin{array}{l}-12.9^{*} \\
(5.70)\end{array}$ & $\begin{array}{l}6.37 \\
(8.30)\end{array}$ \\
\hline Public Works & $\begin{array}{l}-7.14 \\
(5.17)\end{array}$ & $\begin{array}{l}-2.50 \\
(7.54)\end{array}$ \\
\hline Science & $\begin{array}{l}-5.20 \\
(5.41)\end{array}$ & $\begin{array}{l}-2.72 \\
(7.88)\end{array}$ \\
\hline $\begin{array}{l}\text { Small } \\
\text { Business }\end{array}$ & $\begin{array}{l}-19.5 * * * \\
(6.11)\end{array}$ & $\begin{array}{l}-6.95 \\
(8.90)\end{array}$ \\
\hline Veterans & $-19.0 * * *$ & -10.4 \\
\hline
\end{tabular}




\begin{tabular}{|c|c|c|}
\hline Affairs & $(5.20)$ & $(7.57)$ \\
\hline Public & -0.097 & $-0.80 * *$ \\
\hline Mood & $(0.23)$ & $(0.34)$ \\
\hline Constant & $\begin{array}{l}11.6 \\
(16.92)\end{array}$ & $\begin{array}{l}97.1 * * * \\
(24.66)\end{array}$ \\
\hline $\mathrm{N}$ & 530 & 530 \\
\hline R-Squared & .6599 & .3923 \\
\hline F-Statistic & $40.82 * * *$ & $13.58 * * *$ \\
\hline
\end{tabular}

(1)

(2)

(3)

(4)

\begin{tabular}{|c|c|c|c|c|}
\hline $\begin{array}{l}\text { Proportion Women } \\
\text { on Committees }\end{array}$ & $\begin{array}{l}1.10^{* * *} \\
(0.26)\end{array}$ & & $\begin{array}{l}-0.050 \\
(0.38)\end{array}$ & \\
\hline $\begin{array}{l}\text { Number of } \\
\text { Women }\end{array}$ & & $\begin{array}{l}4.87 * * * \\
(0.57)\end{array}$ & & $\begin{array}{l}-0.88 \\
(0.87)\end{array}$ \\
\hline Time & $\begin{array}{l}1.36^{* * * *} \\
(0.17)\end{array}$ & $\begin{array}{l}0.92 * * * \\
(0.16)\end{array}$ & $\begin{array}{l}-1.15^{* * *} \\
(0.24)\end{array}$ & $\begin{array}{l}-1.01 * * * \\
(0.25)\end{array}$ \\
\hline $\begin{array}{l}\text { Democrat } \\
\text { Majority }\end{array}$ & $\begin{array}{l}-5.43^{*} \\
(2.68)\end{array}$ & $\begin{array}{l}-2.31 \\
(2.58)\end{array}$ & $\begin{array}{l}-0.87 \\
(3.91)\end{array}$ & $\begin{array}{l}-1.67 \\
(3.95)\end{array}$ \\
\hline $\begin{array}{l}\text { Democrat } \\
\text { Presidency }\end{array}$ & $\begin{array}{l}0.95 \\
(2.09)\end{array}$ & $\begin{array}{l}1.83 \\
(1.99)\end{array}$ & $\begin{array}{l}-4.86 \\
(3.05)\end{array}$ & $\begin{array}{l}-5.18^{*} \\
(3.04)\end{array}$ \\
\hline Public Mood & $\begin{array}{l}-0.097 \\
(0.23)\end{array}$ & $\begin{array}{l}-0.13 \\
(0.22)\end{array}$ & $\begin{array}{l}-0.80^{* *} \\
(0.34)\end{array}$ & $\begin{array}{l}-0.80^{* *} \\
(0.34)\end{array}$ \\
\hline Constant & $\begin{array}{l}11.6 \\
(16.92)\end{array}$ & $\begin{array}{l}16.4 \\
(16.08)\end{array}$ & $\begin{array}{l}97.1 * * * \\
(24.66)\end{array}$ & $\begin{array}{l}96.3 * * * \\
(24.65)\end{array}$ \\
\hline $\begin{array}{l}\mathrm{N} \\
\mathrm{R} \text {-squared } \\
\text { F-statistic }\end{array}$ & $\begin{array}{l}530 \\
.6599 \\
40.82^{* * *}\end{array}$ & $\begin{array}{l}530 \\
.6929 \\
47.49 * * *\end{array}$ & $\begin{array}{l}530 \\
.3923 \\
13.58 * * *\end{array}$ & $\begin{array}{l}530 \\
.3935 \\
13.65^{* * *}\end{array}$ \\
\hline
\end{tabular}

NOTES: Standard errors are in parentheses. ${ }^{*} \mathrm{p}<0.05,{ }^{* *} \mathrm{p}<0.01, * * * \mathrm{p}<0.001$. Models $1 \& 2$ use the number of oversight hearings as the dependent variable; Models $3 \& 4$ use the number of legislative hearings as the dependent variable. Full estimates are provided in Table A3.2 Appendix. 


\section{Chapter 4: \\ Substantive Representation Revisited: The Relationship of Gender to District Characteristics}

The preceding chapter focused on oversight; the more congresswomen present on a committee, the more oversight hearings regarding women's issues that committee held. This means that not only are women spurring more oversight productivity, but also, they are able to fulfill their desires to represent their female constituents' unique policy needs. In the chapter before last, I found that congresswomen participate more than their male colleagues in hearings considering two women's issue bills that were eventually passed into law. Plus, I found evidence showing that women are more entrepreneurial than their male counterparts. These chapters show that women boost overall activity in the House of Representatives, as well as boosting activity related to women's issues, and they choose to expend their resources focusing on women's issues. Taken together, all of these findings help me build on the literature that links descriptive and substantive representation. Women are actively working to fulfill the role they see themselves as having: representing women, not just their own constituents, but also all women citizens. They recognize, as political scientists do, that women are a minority in a male dominated institution. The role of congresswomen is special: they must bring issues related to women's needs to the table. Simply by being present, women change the policy agenda by making it more inclusive to female citizens as well as make the congressional institution more productive.

In this chapter, I wish to revisit the literature focusing on agenda setting and position taking. In the previous chapters, I have focused on committee participation and committee membership, but here I want to shift the focus back to the individual legislator and their relationship with their own constituents. When women in Congress act differently than their male counterparts, it is easy to assume it is the personal characteristic of being a woman that makes congresswomen act 
differently than congressmen, especially when it comes to women's issues. In other words, being a woman is considered a legitimate reason for explaining congresswomen's behavior on activities where policy pertains directly to women---for example, congresswomen participating more than men in hearings related to women's issues or the presence of congresswomen on committees spurring more oversight hearings on women's issues. In the previous chapters I have argued that descriptive (what a member looks like) and substantive (what a member does) representation are linked, using the two examples in the previous sentence as my empirical cases. After controlling for additional theoretically valid factors, being a woman remains an important (and statistically significant) driving factor for both individual member participation and group actions.

When political scientists study the behavior of individual legislators using gender as an independent variable in their theoretical and statistical models, they tend to control not just for other personal characteristics, such as party, ideology, race, and seniority, but also for district characteristics that may affect lawmakers' behavior. Controlling for district characteristics recognizes the role of reelection concerns in a member's decision-making process. However, the literature that focuses on women in Congress and state legislatures does not include district characteristics that specifically relate to women. If members of Congress are influenced both by their personal policy agendas (Arnold 1990; Fenno 1973; Hall 1996) and reelection concerns (Mayhew 1974), then surely gender of the individual members and the makeup of their constituencies play significant roles in determining bill introductions on women's issues. Therefore, not only do I focus on the individual legislator's gender for this analysis, but I also focus on the characteristics of women within their corresponding congressional districts. Perhaps congresswomen who are elected from certain districts with particular female reelection constituencies are more apt to introduce bills related to women's issues than are congresswomen 
and congressmen from other districts. However, I expect that voters' perceptions of congresswomen allow congresswomen to work on public policies related directly to women's needs and repay them with supportive votes, more so than congressmen. Therefore, my specific research questions are: Is there more to Congresswomen representing women's interests than them being women themselves and general district characteristics? Specifically, do the demographic factors of women in the district matter, and is the effect of gender conditioned by these female demographic factors? I think congresswomen are strategic: they pay attention to the needs of certain female constituencies in their district not only because women's issues interest them, but also because they rely on the voters who are affected by such policy to repay them at the ballot box, and they can do a better job of this than their male counterparts. In the next couple of sections, I will discuss how my research contributes to previous literature concerning women participating in Congress.

\section{Two Pieces to the Puzzle: Congresswomen and the District}

\section{CONGRESSWOMEN}

Having women in Congress changes the gender dynamics of a male dominated institution, as well as adds important ideas to the policy agenda. Not only do women differentiate themselves from their male colleagues in their advocacy for issues that directly affect women in the electorate, but also, they are more effective legislators, where effectiveness is defined as "the advancement of a member's agenda items through the legislative process and into law" (Volden, Wiseman, \& Wittmer 2013; 327). Past research also shows that having women present in Congress does make a substantive difference in the legislative agenda (e.g., Swers 2002a; 2013). For example, congresswomen use their committee positions to advocate for the incorporation of women's interests into committee legislation (Dodson 1998, 2002; Dodson et al.1995; Gertzog 1995; Norton 
2002; Swers 2002a). When women in the House are able to pursue any issue that interests them and their constituents, they choose to introduce legislation related to gender and family more than their male colleagues (Swers 2002a). Similarly, in state legislatures, Bratton (2005) finds that women sponsor more women's interest legislation than their male counterparts, even when the legislature contains very few women.

Gender also seems to make a difference in position-taking behaviors, such as roll call voting and floor debate. When the policy directly concerns gender, like abortion (Tatolovich and Schier 1993) or a set of women's issues (Burrell 1994; Dolan 1997; Swers 1998), female representatives tend to vote similarly, somewhat disregarding ideology and partisanship. Furthermore, during floor debates, women exhibit a higher rate of participation than their male counterparts on women's issues (Cramer Walsh 2002; Swers 2001; Tamerius 1995), as well as speaking with a distinctive voice on such issues (Cramer Walsh 2002; Dodson et al. 1995; Levy, Tien, and Aved 2001; Swers 2001).

Why would women take on the responsibility of pursuing policy change in regards to women's issues? Part of it has to do with representing female citizens. Women serving in both state legislatures and Congress feel a responsibility to specifically represent women. They think of women as a distinct constituency and express commitment to representing women, whether in their district or not (Carroll 2002; Dodson et al. 1995; Foerstel and Foerstel 1996; Gertzog 1995). These findings are exemplified in the behaviors listed above, but also (and most importantly for the current purposes of this chapter) agenda setting behavior. At the state level, female representatives prioritize women's issues. They pursue feminist initiatives and legislation, as well as legislation concerning issues of traditional importance to women, such as education, health, and welfare (Berkman and O'Connor 1993; Dodson and Carroll 1991; Dolan and Ford 1995; Saint-Germain 
1989; Thomas 1994). In Congress, women sponsor and cosponsor more feminist bills ${ }^{36}$ and bills related to women's traditional role as caregiver ${ }^{37}$ than men (Swers 2000, 2002; Tamerius 1995; Vega and Firestone 1995; Wolbrecht 2002). Therefore, I expect congresswomen to continue to introduce more bills of particular concern to women than their male counterparts.

Women may be interested in pursuing women's issues on their personal agendas due to the fact that they themselves are women, have a personal connection to their gender identity, and they have an interest in doing so simply because they can relate to those issues. They may also feel a specific responsibility to represent women, since women are so underrepresented in Congress. Taking both of these possibilities into account, I feel that because reelection is also a paramount concern to all members, women can capitalize on their gender by purposefully representing the unique needs of the women within their district. They can do this despite their party affiliation because they are women. Men are at a disadvantage. In the next section, I will discuss why the district can help us explain bill introduction behavior, and how this can further our understanding of the link between descriptive and substantive representation.

\section{THE DISTRICT}

Certain kinds of districts are more likely to elect women. Palmer and Simon (2006) find districts that elect Democratic women are more liberal than districts that elect Democratic men. Therefore, I can expect to see evidence that both women and liberal members will introduce more bills related to women's interests. Considering geography, non-Southern, urban, and small Democratic districts are places where Democratic women can expect to be successful. There are also some unique characteristics to the districts electing white Democratic women. These districts

\footnotetext{
${ }^{36}$ Examples: reproductive rights, protecting victims of domestic violence, increasing funding for women's health research, establishing gender equality programs in education, etc.

${ }^{37}$ Examples: health care, education, poverty assistance
} 
tend to be wealthier than the districts that elected men, have smaller blue-collar populations, and a larger proportion of college graduates. As for Republican women, the districts electing them are more moderate than those electing men. The districts tend to be smaller, outside the South, have larger urban populations than the districts electing Republican men; however, for both Republican men and women, their districts are not racially diverse. Districts electing women are definitely unique in comparison to those electing men, "but it is important to keep in mind that core Democratic districts electing a woman are still more Democratic and liberal than core Republican districts electing a woman" (Palmer and Simon 2006; 198-199).

Because of the evidence found by Palmer and Simon coupled with the evidence presented in the previous section regarding women's propensity to work on women's issues more so than their male colleagues, I expect a few different things related to partisanship and gender. I expect both female Democrats and female Republicans to be more responsive to female constituencies because this results in votes from women, but also because congresswomen are more interested in representing the needs of women via women's issue legislation than their male counterparts. I separate Democrats and Republicans in some of the models presented in the forthcoming analysis, but also control for party in other models, so that I can tease out the differences between a liberal responsiveness to women's issues versus a congresswoman's responsiveness to her female constituency. In other words, it is important to tease out whether Democrats are providing their liberal constituents with what they expect from the Democratic party platform, or if women within both parties are extending the connection between descriptive and substantive representation to bill introduction behavior.

If Democrats of both genders introduce more women's issue legislation than their Republican colleagues, then it's a story about partisan issues and the Democrats' ownership of 
women's issues (i.e. Petrocik 1996). If just female Democrats introduce more legislation than Democratic men and Republicans of both genders, then it's a story connecting gender (their wanting to represent women) and party (issue ownership). However, if as I expect, female Democrats and female Republicans introduce more legislation, then it's a story of gender and district characteristics, and party falls away. As mentioned above, female legislators have expressed a sense of responsibility to represent the interests of women and they are more likely than men to view women as a distinct part of their constituencies (Carroll 2002; Dodson et al. 1995; Foerstel and Foerstel 1996; Gertzog 1995; Reingold 1992; Thomas 1994, 1997). Besides Republican women seeking to represent the needs of women, it's a good electoral strategy to remain responsive to the unique female constituencies within their districts. Republican women can get away with "poaching" issue ownership of women's issues away from Democrats compared to Republican men because they themselves are usually wives and mothers (Swers 2016A). They have "expertise" on women's issues by virtue of their gender roles and femininity. Furthermore, we can expect women of both parties might have an advantage over men due to voters' cognitive shortcuts (Popkin 1991). Voters will understand why women would choose to focus on these issues, but this would be harder for men, especially Republican men to do. In other words, I think this is a deliberate campaign and representation strategy. Not only will members of Congress listen to the concerns of their constituents, but I believe that because congresswomen express a specific interest in representing women constituents, they will be more likely than men to pay attention to their female constituents' wants and needs.

We know from Fenno that there are many different constituencies, so congresswomen might have advantages building female constituencies relative to congressmen. In other words, being a woman has an effect on their behavior because gender is an inherently identifying 
characteristic, but is it gender in conjunction with being in the right district that better predicts their behavior? These are important questions to address since the literature is not currently addressing them. By not recognizing them theoretically and evaluating them empirically we are missing out in terms of our understanding of how and why women's interests receive representation in Congress. When female members go to Congress, they can choose to exploit their connection to female voters, which conditions the effect of gender on their behavior. In other words, congresswomen are able to introduce women's issue bills, which might be a true interest of theirs, but it also appeases the women in their district who voted for them. It may even help win over women who didn't vote for them, but who pay close attention to their 'sister' in office. In this chapter, I will address these questions of gender interacting with characteristics of women in the district by examining bill introductions concerning women's issues.

\section{Is Gender Conditioned by District (or Reelection) Characteristics?}

We know that partisanship plays a large role in member behavior, but we also know that congresswomen act substantively different than congressmen, especially when it comes to women's issues. If this is the case, why can we expect Republican and Democratic women to represent their female constituents in similar ways? When considering modeling the relationship between members of Congress and their bill introductions, I want to capture personal motivations as well as reelection motivations in order to fully specify the model. Thinking about the causal story of gender and a member's behavior and what previous authors have added to this area of literature, I realized that no authors were adding characteristics about the female population of the congressional districts to their models. Previous authors (Poggione 2004; Swers 2002a) took district and thus reelection interests into account by controlling for average household income, the percentage unemployed in the district, the percentage of district residents who earned a college 
degree, and urbanicity. These variables also helped control for the liberalness of the district. Yet, they did not consider the possible relationship between particular groups of female reelection constituencies and a member's behavior. What if gender is conditioned by a district characteristic? Or more importantly, what if gender is conditioned by a district characteristic specifically related to the women of the district?

I expect women to consciously seek to represent the unique needs of women, so I expect congresswomen to pay particular attention to the needs of the women in their district that are affected by special policies. The categories of women I chose for the forthcoming analysis are at the mercy of data availability, but I wanted to choose variables or groups of women based on that group's likelihood of benefitting from an agenda focused on women's interests. We can expect women in Congress to have an agenda that matches those groups' concerns. For example, divorced women are in need of economic policies to help single income families (alimony or child support), housing policies, policies benefitting children and parent's rights or custody rights, mental health care, etc. Children in poverty require food, healthcare, and income assistance, as well as education and housing. Lesbian couples seek protections of their civil rights and other policies for children if they are parents, and female veterans require benefits related to their status as veterans. All four of these groups require special and specific policy solutions to their unique problems as women and are included in the analysis. The wealthy women are included because wealthy and educated people respond that they care about women's issues in public opinion surveys (Lewis-Beck et al 2008). This group may not need any special gender-based policy, but if they report that they care about women's issues, we can expect members of Congress to pay attention to those opinions, and we already expect congresswomen to do a better job of this than men. By including these five categories of district characteristics, I seek to ascertain whether district characteristics that signal 
how much constituents would benefit from policies beneficial to women's interests condition the influence of gender on congresswomen's bill sponsorship behavior. Congresswomen may be more responsive than congressmen in such districts not only because they may be personally more interested in doing so, but because they will take advantage of voter expectations and seek an electoral reward for their substantive representation.

\section{DATA AND Methods}

Swers calls gender a "fundamental identity that affects the way senators look at policy questions, the issues they prioritize, and the perspective they bring to develop solutions" (2013, 3). However, the fundamental identity is not enough to explain behavioral differences between male and female members due to other factors like party identification. She goes on to argue that senators develop political and electoral strategies based on public expectations regarding gender roles and party reputations. If we take her findings into account along with the previous discussion of reelection concerns, it is easy to see how important it is to account for the member's gender and the member's district characteristics. Perhaps female legislators from both parties keep the women of their district in mind for both personal interest, like Hall would expect, and for reelection interests, like Fenno would expect. Plus, both Republican and Democratic women exhibit an interest in working on and producing women's issue legislation, not to mention they see women as a specific group that needs deliberate representation.

I predict being female to have a positive relationship with bill sponsorship related to women's issues based on these previous findings. I also expect that some of the interactions I include to condition gender. Therefore, I think this relationship between district characteristics and bill introduction behavior may exist for female members because we should expect them to exploit gender through their "linked fate" with female voters. Again, this is why it is important to 
recognize the role of partisanship. Congresswomen in general can be expected to introduce more women's issue legislation than their male colleagues, but if this trend holds when models are run separating out the parties, and women introduce more legislation than men within their own parties, then there is more than a connection between Democratic party issue ownership and action on women's issues. Rather, women seek to represent the special needs of women in their district in hope of an electoral reward.

DEPENDENT VARIABLE ${ }^{38}$. This analysis focuses on the House of Representatives during the $109^{\text {th }}-113^{\text {th }}$ congressional sessions $(2005-2014)$, as those are the only sessions where the Census has data available at the congressional district level, rather than county level. This is an interesting time period, however. It is close in proximity to our current time period, which updates the current state of the literature concerning bill sponsorship on women's issues, and it includes instances of both unified and divided government ${ }^{39}$. In some of the models I limit the congressional sessions to 111 th to the 113 th because there is missing data for some of the Census variables, which I will discuss in the next section. The dependent variable in all models consists of a count of women's issue bill introductions, as defined by Swers (2002, 36-38), per member per congressional session. She uses the websites of different women's organizations, liberal, conservative, and nonpartisan, to determine what kinds of issues are of interest to those organizations, and thus would be considered women's issues ${ }^{40}$. In general, these are social welfare policies and policies related to women's traditional gendered role as caregivers and mothers. In order to code the hearings as women's issues, I coded the Policy Agendas Project subtopics for whether or not they covered

\footnotetext{
${ }^{38}$ Data sources, definitions, and descriptive statistics for Chapter 4 can be found in Table A4.1 of the Appendix.

${ }^{39}$ Here I'm only concerned with the House and the President; I'm not including the Senate in my use of united or divided, since I am only studying House bill introductions. 109 \& 111= united; 110, 112, \& 113 $=$ divided.

${ }^{40}$ For a complete breakdown of Swers' coding schema, please refer to Appendix Table A4.2
} 
women's issues as defined by the women's organizations provided by Swers. By coding the subtopics for whether or not they are women's interest topics, I was also able to code the introductions for being women's interest bills because the Congressional Bills Project dataset includes each bill's subtopic code. A second coder also coded the subtopics, testing the coding for reliability. The inter-coder reliability test, presented in the Appendix (see Table A4.3), shows the amount of agreement and indicates that I can reject the null hypothesis that the coding criteria does not improve agreement beyond that which one would observe if both coders simply chose the modal category (not a women's issue). This finding supports the view that certain subtopics were explicitly related to the women's issues highlighted by the women's organizations.

I use the Congressional Bills Project dataset (Adler \& Wilkerson 2013) ${ }^{41}$ to gather the universe of bill introductions limiting the data to the House. I will present estimates from negative binomial maximum likelihood models, which are appropriate for count data that is overdispersed. Many members have a zero observation for the dependent variable (introducing no women's issue bills), so negative binomial regression is more appropriate than OLS regression.

INDEPENDENT VARIABLES. Gender $(1=$ female, $0=$ male $)$ is one of the variables of main interest. Party identification $(1=$ Republican, $0=$ Democrat $)$ is used in all the models presented in this chapter because it is theoretically relevant to explaining member behavior. I also include a measure of whether or not $\left(1=\right.$ yes; $0=$ no) the member was a part of the majority party ${ }^{42}$. I do this because I am interested in whether a member's majority or minority status affects their productivity. As we have seen in the previous chapters, women tend to be active whether they are Democrats or Republicans, and in both positions of the majority and minority. I expect to see similar results here. In Appendix Table A4.4, I present the results of models interacting gender

\footnotetext{
${ }^{41}$ I thank E. Scott Adler and John Wilkerson for making this data publicly available.

${ }^{42}$ Majority party: 109, 112, 113 Republican; $110 \& 111$ Democrat
} 
and partisanship as well as gender and majority party status in comparison to the base model presented in column 1. This model is also the base model in column 1 of Table 4.1 discussed below. The purpose of Table A4.4, as well as Table A4.5 in the Appendix is to show that these interactions of partisanship and gender have no significantly different effect on the model's results, so they are not necessary to include in the models presented below. Also, there is basically no difference between using party identification and ideology measures in the models. Ideology (first dimension DW-NOMINATE scores) is included in the full models presented in Appendix Table A4.6 to illustrate this.

Other independent variables of interest attempt to capture district characteristics and possible reelection constituency characteristics previously left out of the models in previous literature. My main contribution will be to investigate how important congressional reelection constituencies within districts are to women in ways other than those constituencies' party identification or ideology. Again, my main research question asks whether groups of women or girls of the district affect the way women in Congress choose to represent them via bill sponsorship. In this chapter, I include the following: divorced women, wealthy women ${ }^{43}$, girls under five living in poverty, lesbian couples, and female veterans. The logs of these variables are used in the models.

I use congressional district level data from $109^{\text {th }}$ through the $113^{\text {th }}$ congressional sessions ${ }^{44}$. These data are compiled from the American Communities Survey ${ }^{45}$. The main contribution here is to use data that authors in this particular area of women and politics (considering substantive representation) have not considered before in order to explain the connection between female

\footnotetext{
${ }^{43} \mathrm{I}$ am defining wealthy as those women making over $\$ 100,000$ in the current congressional session year.

${ }^{44}$ Those sessions are the only data available sorted by sex and congressional district.

${ }^{45}$ These data have been collected via the American FactFinder.
} 
members of the House and their female reelection constituencies. I expect women within congressional districts to be an important influence on women in Congress of both parties. Because congressional women, when interviewed (Carroll 2002), indicate a serious intent and responsibility towards representing women, I do not think we can safely capture all of that influence with the gender dummy variable. I think we need to include the district characteristics specifically related to women in the district in order to fully specify the model to match up with our theoretical expectations---that congresswomen pay attention to their female constituents. Plus, we are further bolstering the link between descriptive and substantive representation. Women in Congress act differently than men due to their policy interests, their reelection interests, and these are connected via the interests of women within their congressional districts.

Therefore, I plan to: (1) use the five new Census variables denoting women's interests in the district to explain why the women in Congress may have an advantage over the men, and (2) how these new variables about women may condition the effects of gender on bill introduction behavior. The novelty of my work is found in updating the years studied, the additional variables related to women in the district, and interaction terms.

CONTROL VARIABLES. Two other district characteristics are included to capture the makeup of the district: the total Black population and the median household income. These variables are used to determine whether the district leans toward a liberal ideology, and thus may be more likely to elect a female or a Democrat (or both) (Palmer \& Simon 2006). The logs of these variables are used in the models. The log of the number of women serving in the House is included in order to capture any effect this may have because as time goes on, more women serve, and the more women who serve, the more women's issue legislation we can expect to see introduced. I also included dummy variables for the congressional sessions. However, there is basically no difference between 
the models that include fixed effects and those that do not, so I do not include them in the full models presented here in the chapter. Two sessions also drop out due to collinearity. Those models can be viewed in the Appendix (Table A4.6).

\section{Results}

Similar to the results in the previous chapters, the women of the House are more productive when it comes to women's issues than their male counterparts. As presented first in column 1 of Table 4.1, they introduce more bills related to women's issues at a significance level of $\mathrm{p}<0.001$. This means that overall, women of both parties introduce more women's issue bills than their male colleagues during the time period examined (January 2005-January 2015), even when controlling for party identification, majority party membership, unified government, the number of women serving, and traditional measurements of district characteristics, black population, and median household income. Being a Democrat or being a member of the majority party, as well as having more black constituents or a higher median household income motivates members of the House to sponsor women's issue legislation. This trend holds when I run the model for Democrats only, as presented in column 2. Democrats tend to own women's issues (Petrocik 1996), meaning that they are perceived to be authentic authorities on this policy area, so again this result is not surprising. When we consider the expressed interest in representing the needs of women by congresswomen, coupled with their party's ownership of women's issues, it makes sense that female Democrats will introduce more legislation than male Democrats. They are in a unique position to exploit voter expectations as both women and Democrats by introducing women's interest legislation and reaping the electoral benefits.

However, in column 3 of Table 4.1, I present the model for Republicans only. Here, female Republicans are introducing more women's issue bills than Republican men at a statistically 
significant level. This indicates to me that the story is not just a connection between issue ownership and congresswomen, but rather women in both parties institute the same, or at least a similar representative strategy. By sponsoring more bills related to women's issues than their male colleagues, women in both parties are expressing their interest in representing the unique policy needs of women. This allows them to introduce legislation they are interested in as women themselves, but also to introduce legislation that benefits their constituents and be rewarded with reelection. Again, I think they are able to do this better than the men in their party because their strategy is to be rewarded by particular reelection constituencies.

Evidence of the connection between such female reelection constituencies is explored first in Table $4.2^{46}$. Each column adds in a different female constituency variable. Only the number of wealthy women (column 2) and the number of lesbian households (column 4) have a positive and statistically significant relationship with the dependent variable. This indicates that these particular types of female constituencies contribute to a member's likelihood of introducing women's issue bills. Divorced women, girls in poverty under five, and female veterans do not, however. The impact of gender and party identification hold across all models: being a woman and being a Democrat leads to more women's issue bill sponsorships, as does majority party membership, more female members in the House, and a higher median household income within the district.

These results lead me to present the models in Table 4.3. What happens when all of the female reelection constituency variables are included in the same model? In column 1, the effect of being a congresswoman, being a Democrat, being a member of the majority party, having a unified government, more congresswomen present, more wealthy women, and a higher median household income hold. When I split apart Democrats and Republicans, the effects change. In

\footnotetext{
${ }^{46}$ Note Table 4.2, 4.3, and 4.4 must limit the congressional sessions to 111,112 , and 113 because not all of the Census variables related to female constituencies are available in 109 and 110 .
} 
column 2, among Democrats, women sponsor more legislation than men related to women's issues at the $\mathrm{p}<0.01$ level. Also, the more lesbian households, the more bills introduced by female Democrats. However, the statistically significant effect of wealthy women drops out. Now there is a negative statistically significant relationship between the number of divorced women and bill introductions. When considering these results in comparison to column 3 , which only includes Republicans, female Democrats seem to be driving the results observed in column 1. No variable except median household income in the district has a positive and statistically significant relationship with bill introductions for Republicans. Overall, partisanship and issue ownership by Democrats seem to predict women's behavior more so than district characteristics. However, lesbian households and wealthy women may be important female reelection constituencies for female Democrats.

To further explore the connection between the gender of a member and their possible female reelection constituency, I ran models testing whether the female reelection constituency variables condition the positive and significant effects of being a congresswoman. Each model adds in a different statistical interaction of the gender of a member with a female reelection variable. The interactions of gender and divorced women, gender and wealthy women, gender and girls living in poverty, and gender and lesbian households all take away the positive and statistically significant relationship between being a congresswoman and sponsoring more women's issue bills. Only in model 5 does the positive and statistically significant relationship hold. These findings do not indicate that the relationship between gender and bill sponsorship disappears. Rather, when I model the relationships in a conditional way, the relationship does not appear as an interaction. Instead, the relationship is better modeled additively and not conditionally. 
General trends that hold across all five models indicate that being a Democrat, a member of the majority party, having united government, having more women serving in the House, and a higher median household income within the district are strong indicators of a member's women's interest bill introductions. These types of members sponsor more legislation, but the important causal story of a conditional relationship between being a female member and female reelection constituencies does not present itself. If we observed these interaction terms attaining statistical significance while the congresswomen coefficients lost significance, then I could have concluded that there was a conditional relationship between being a congresswoman and the female reelection constituencies. However, a strong connection between Democrats and women's issue bill introductions, and in particular Democratic women and bill introductions are the key findings. The causal story is somewhat complicated. I do not find evidence of a conditional relationship, but importantly I do find that female Democrats are able to use their party's issue ownership to introduce legislation that we expect them to based on both partisanship and gender. I still believe congresswomen want to represent the unique needs of women as well as reap the reelection rewards from their possible female reelection constituencies. It seems that in certain circumstances female Democrats are better able to do this than female Republicans, but in general women of both parties are outperforming the men within their own party. This chapter presents further evidence of a connection between descriptive and substantive representation via women's issue bill sponsorship.

\section{Discussion}

Overall, it is clear that partisanship plays a crucial role in predicting member behavior. In particular, all models show a strong relationship between being a Democrat and sponsoring more 
women's issue legislation. The relationship between gender and women's issue bill introductions is indeed affected by some district level characteristics, however.

This chapter, along with the findings in the previous chapters, present a preponderance of evidence that gender matters in spurring congresswomen to act more than their male counterparts when it comes to women's issue legislation and representing female constituents. I have found that congresswomen participate more than congressmen in hearings related to women's issue legislation. Plus, women are more entrepreneurial than men overall. These findings bolster findings on effectiveness and are theoretically relevant: simply electing women to Congress changes the dynamic of the institution. Having more women present makes the institution more productive and brings unique voices to the table. Similarly, I found that female members of the House spur more oversight related to women's issues simply by being present on committees: the greater the female membership of a committee, the more oversight hearings the committee held considering women's issues.

In the current chapter, I found that women in Congress overall are more willing to sponsor women's issue bills, but the findings are more consistent for female Democrats compared to female Republicans. I believe that Democratic women are fulfilling their goal of creating good public policy related to women, and that this helps them fulfill their other goal of reelection. Particular constituencies, like wealthy women and lesbians help spur more action from female Democrats, and thus may represent specific and important female reelection constituencies for those members. Democratic congresswomen should pay close attention to those two groups in order to substantively represent their policy needs and be rewarded with reelection. However, if congresswomen in general are interested in the welfare of all women, including the five groups investigated here, and policy dealing with women's issues, then congresswomen, both Democrats 
and Republicans, would benefit from attempting to accommodate the wishes of all women. Of course, partisanship of these women plays an important role, however districts that elect Republican women are more moderate than those electing Republican men (Palmer \& Simon 2006). Perhaps female Republicans can construct a political calculus that poaches women's issues from Democrats in order to capitalize on their own gender in relation to the women in their district. We do not see evidence of this holding across all models presented here, but it may be a necessary electoral strategy moving forward. In the next chapter, I will discuss the findings and limitations of the previous chapters, as well as discuss potential extensions of the research and directions for future research in the gender and politics discipline. The work presented in this dissertation has built on the literature, but has also given me many ideas on how to further explore the connection between descriptive and substantive representation. 


\section{Chapter 4 Tables and Figures}

Table 4.1: The Effect of Gender on Introducing Women's Issue Bills, $109^{\text {th }}-113^{\text {th }}$ Congress

\begin{tabular}{|c|c|c|c|}
\hline & (1) & (2) & (3) \\
\hline Congresswomen & $\begin{array}{l}0.21 * * * \\
(0.05)\end{array}$ & $\begin{array}{l}0.23 * * * \\
(0.06)\end{array}$ & $\begin{array}{l}0.20 * * \\
(0.08)\end{array}$ \\
\hline Party Identification & $\begin{array}{l}-0.32 * * * \\
(0.04)\end{array}$ & & \\
\hline Majority Party & $\begin{array}{l}0.11^{* * *} \\
(0.04)\end{array}$ & $\begin{array}{l}0.18^{* * *} \\
(0.05)\end{array}$ & $\begin{array}{l}0.061 \\
(0.05)\end{array}$ \\
\hline United Government & $\begin{array}{l}0.070 \\
(0.04)\end{array}$ & $\begin{array}{l}0.032 \\
(0.06)\end{array}$ & $\begin{array}{l}0.11^{*} \\
(0.06)\end{array}$ \\
\hline $\begin{array}{l}\text { Log Number } \\
\text { Congresswomen }\end{array}$ & $\begin{array}{l}0.21 \\
(0.41)\end{array}$ & $\begin{array}{l}0.45 \\
(0.59)\end{array}$ & $\begin{array}{l}0.23 \\
(0.57)\end{array}$ \\
\hline $\begin{array}{l}\text { Log Black } \\
\text { Population }\end{array}$ & $\begin{array}{l}0.027^{*} \\
(0.02)\end{array}$ & $\begin{array}{l}0.020 \\
(0.02)\end{array}$ & $\begin{array}{l}0.027 \\
(0.03)\end{array}$ \\
\hline $\begin{array}{l}\text { Log Median } \\
\text { Household Income }\end{array}$ & $\begin{array}{l}0.58 * * * \\
(0.07)\end{array}$ & $\begin{array}{l}0.41 * * * \\
(0.09)\end{array}$ & $\begin{array}{l}0.83^{* * *} \\
(0.11)\end{array}$ \\
\hline Constant & $\begin{array}{l}-5.77 * * \\
(1.94)\end{array}$ & $\begin{array}{l}-4.85^{*} \\
(2.73)\end{array}$ & $\begin{array}{l}-8.80 * * * \\
(2.79)\end{array}$ \\
\hline $\begin{array}{l}\text { Log Alpha } \\
\text { Constant }\end{array}$ & $\begin{array}{l}-0.63 * * * \\
(0.04)\end{array}$ & $\begin{array}{l}-0.58 * * * \\
(0.05)\end{array}$ & $\begin{array}{l}-0.71 * * * \\
(0.06)\end{array}$ \\
\hline $\mathrm{N}$ & 2362 & 1175 & 1187 \\
\hline Pseudo R-squared & 0.01 & 0.01 & 0.01 \\
\hline
\end{tabular}

Note: Model 1 = all members; Model 2 = just Democrats; Model 3 = just Republicans. Variance exceeds the mean indicating negative binomial regression is appropriate. Standard errors in parentheses. $* \mathrm{p}<0.05$, $* * \mathrm{p}<0.01, * * * \mathrm{p}<0.001$.

Table 4.2: The Effect of Gender on Introducing Women's Issue Bills Adding in Variables Related to Women in the District, $111^{\text {th }}-113^{\text {th }}$ Congresses
(1)
(2)
(3)
(4)
(5)

\begin{tabular}{llllll}
\hline Congresswomen & $0.17 * *$ & $0.15^{* *}$ & $0.17 * *$ & $0.17 * *$ & $0.17 * *$ \\
& $(0.06)$ & $(0.06)$ & $(0.06)$ & $(0.06)$ & $(0.06)$ \\
Party Identification & $-0.32 * * *$ & $-0.31 * * *$ & $-0.33 * * *$ & $-0.33 * * *$ & $-0.32 * * *$
\end{tabular}




\begin{tabular}{|c|c|c|c|c|c|}
\hline & $(0.05)$ & $(0.05)$ & $(0.05)$ & $(0.05)$ & $(0.05)$ \\
\hline Majority Party & $\begin{array}{l}0.087^{*} \\
(0.05)\end{array}$ & $\begin{array}{l}0.091^{*} \\
(0.05)\end{array}$ & $\begin{array}{l}0.091^{*} \\
(0.05)\end{array}$ & $\begin{array}{l}0.088^{*} \\
(0.05)\end{array}$ & $\begin{array}{l}0.088^{*} \\
(0.05)\end{array}$ \\
\hline United Government & $\begin{array}{l}0.14 * * \\
(0.05)\end{array}$ & $\begin{array}{l}0.16^{* *} \\
(0.06)\end{array}$ & $\begin{array}{l}0.15^{* *} \\
(0.05)\end{array}$ & $\begin{array}{l}0.15^{* *} \\
(0.05)\end{array}$ & $\begin{array}{l}0.15^{* *} \\
(0.05)\end{array}$ \\
\hline $\begin{array}{l}\text { Log Number } \\
\text { Congresswomen }\end{array}$ & $\begin{array}{l}1.07^{*} \\
(0.61)\end{array}$ & $\begin{array}{l}1.01^{*} \\
(0.60)\end{array}$ & $\begin{array}{l}1.04 * \\
(0.60)\end{array}$ & $\begin{array}{l}1.31^{*} \\
(0.62)\end{array}$ & $\begin{array}{l}1.05^{*} \\
(0.60)\end{array}$ \\
\hline $\begin{array}{l}\text { Log Black } \\
\text { Population }\end{array}$ & $\begin{array}{l}0.025 \\
(0.02)\end{array}$ & $\begin{array}{l}-0.0000015 \\
(0.02)\end{array}$ & $\begin{array}{l}0.019 \\
(0.02)\end{array}$ & $\begin{array}{l}0.024 \\
(0.02)\end{array}$ & $\begin{array}{l}0.023 \\
(0.02)\end{array}$ \\
\hline $\begin{array}{l}\text { Log Median } \\
\text { Household Income }\end{array}$ & $\begin{array}{l}0.47 * * * \\
(0.09)\end{array}$ & $\begin{array}{l}0.12 \\
(0.18)\end{array}$ & $\begin{array}{l}0.56 * * * \\
(0.14)\end{array}$ & $\begin{array}{l}0.47 * * * \\
(0.09)\end{array}$ & $\begin{array}{l}0.48 * * * \\
(0.09)\end{array}$ \\
\hline $\begin{array}{l}\text { Log Divorced } \\
\text { Women }\end{array}$ & $\begin{array}{l}-0.10 \\
(0.12)\end{array}$ & & & & \\
\hline $\begin{array}{l}\text { Log Wealthy } \\
\text { Women }\end{array}$ & & $\begin{array}{l}0.14^{* *} \\
(0.06)\end{array}$ & & & \\
\hline $\begin{array}{l}\text { Log Girls Under } \\
\text { Five in Poverty }\end{array}$ & & & $\begin{array}{l}0.042 \\
(0.06)\end{array}$ & & \\
\hline $\begin{array}{l}\text { Log Lesbian } \\
\text { Households }\end{array}$ & & & & $\begin{array}{l}0.075^{*} \\
(0.04)\end{array}$ & \\
\hline $\begin{array}{l}\text { Log Women } \\
\text { Veterans }\end{array}$ & & & & & $\begin{array}{l}-0.043 \\
(0.04)\end{array}$ \\
\hline Constant & $\begin{array}{l}-7.26 * * \\
(3.06)\end{array}$ & $\begin{array}{l}-5.13^{*} \\
(3.08)\end{array}$ & $\begin{array}{l}-9.44 * * \\
(3.24)\end{array}$ & $\begin{array}{l}-9.76 * * * \\
(2.87)\end{array}$ & $\begin{array}{l}-7.96 * * \\
(2.79)\end{array}$ \\
\hline $\begin{array}{l}\text { Log Alpha } \\
\text { Constant }\end{array}$ & $\begin{array}{l}-0.70 * * * \\
(0.05)\end{array}$ & $\begin{array}{l}-0.71 * * * \\
(0.05)\end{array}$ & $\begin{array}{l}-0.70 * * * \\
(0.05)\end{array}$ & $\begin{array}{l}-0.70 * * * \\
(0.05)\end{array}$ & $\begin{array}{l}-0.70 * * * \\
(0.05)\end{array}$ \\
\hline $\begin{array}{l}\mathrm{N} \\
\text { Pseudo R-squared }\end{array}$ & $\begin{array}{l}1400 \\
0.01\end{array}$ & $\begin{array}{r}1400 \\
0.01\end{array}$ & $\begin{array}{l}1400 \\
0.01\end{array}$ & $\begin{array}{l}1399 \\
0.01\end{array}$ & $\begin{array}{l}1400 \\
0.01\end{array}$ \\
\hline
\end{tabular}

Note: Variance exceeds the mean indicating negative binomial regression is appropriate. Standard errors in parentheses. $* \mathrm{p}<0.05, * * \mathrm{p}<0.01, * * * \mathrm{p}<0.001$.

Table 4.3: Fully Specified Model of the Effect of Gender on Introducing Women's Issue Bills, $111^{\text {th }}-113^{\text {th }}$ Congresses
(1)
(2)
(3)

Congresswomen

$0.14 *$

$0.17 * *$

0.067 
$\begin{array}{lll}(0.06) & (0.07) & (0.11)\end{array}$

Party Identification $\quad-0.28 * * *$

(0.05)

Majority Party

$0.092 *$

$0.26 * * *$

$-0.068$

(0.05)

(0.08)

(0.08)

United Government $\quad 0.17 * *$

(0.06)

Log Number

Congresswomen

$1.42 *$

1.93*

1.29

(0.63)

(0.94)

(0.86)

Log Black

0.0019

0.0072

$-0.031$

Population

(0.02)

(0.03)

(0.04)

Log Median

0.16

$-0.0090$

$0.68 *$

Household Income

(0.23)

(0.30)

(0.39)

Log Divorced

$-0.24$

$-0.39^{*}$

0.18

Women

(0.16)

$(0.22)$

(0.26)

Log Wealthy

$0.13 *$

0.069

0.11

Women

$(0.07)$

(0.09)

(0.12)

Log Girls Under

0.052

0.033

0.0012

(0.06)

(0.09)

(0.10)

Log Lesbian

$0.077^{*}$

$0.12 *$

0.028

Households

(0.05)

(0.06)

(0.07)

Log Women

$-0.0089$

$-0.072$

0.12

Veterans

(0.05)

(0.07)

(0.08)

Constant

$-5.68$

$-3.62$

$-15.1^{*}$

(4.10)

(5.52)

(6.51)

Log Alpha

$-0.71 * * *$

$-0.72 * * *$

$-0.76^{* * *}$

Constant

(0.05)

(0.07)

(0.08)

\begin{tabular}{llll}
\hline $\mathrm{N}$ & 1399 & 700 & 699 \\
Pseudo R-squared & 0.02 & 0.01 & 0.01 \\
\end{tabular}

Note: Model 1 = all members; Model 2 = just Democrats; Model 3 = just Republicans. Variance exceeds the mean indicating negative binomial regression is appropriate. Standard errors in parentheses. ${ }^{*} \mathrm{p}<0.05$, $* * \mathrm{p}<0.01, * * * \mathrm{p}<0.001$. 
Table 4.4: The Effect of Gender on Introducing Women's Issue Bills Adding in Variables Related to Women in the District and Interaction Terms, $111^{\text {th }}-113^{\text {th }}$ Congresses

\begin{tabular}{|c|c|c|c|c|c|}
\hline & (1) & (2) & (3) & (4) & (5) \\
\hline Congresswomen & $\begin{array}{l}1.53 \\
(2.80)\end{array}$ & $\begin{array}{l}-0.11 \\
(0.65)\end{array}$ & $\begin{array}{l}-0.93 \\
(0.84)\end{array}$ & $\begin{array}{l}-0.83 \\
(0.64)\end{array}$ & $\begin{array}{l}1.32 * \\
(0.69)\end{array}$ \\
\hline Party Identification & $\begin{array}{l}-0.32 * * * \\
(0.05)\end{array}$ & $\begin{array}{l}-0.31 * * * \\
(0.05)\end{array}$ & $\begin{array}{l}-0.34 * * * \\
(0.05)\end{array}$ & $\begin{array}{l}-0.32 * * * \\
(0.05)\end{array}$ & $\begin{array}{l}-0.32 * * * \\
(0.05)\end{array}$ \\
\hline Majority Party & $\begin{array}{l}0.087^{*} \\
(0.05)\end{array}$ & $\begin{array}{l}0.092^{*} \\
(0.05)\end{array}$ & $\begin{array}{l}0.090^{*} \\
(0.05)\end{array}$ & $\begin{array}{l}0.085^{*} \\
(0.05)\end{array}$ & $\begin{array}{l}0.092^{*} \\
(0.05)\end{array}$ \\
\hline United Government & $\begin{array}{l}0.14^{* *} \\
(0.05)\end{array}$ & $\begin{array}{l}0.16^{* *} \\
(0.06)\end{array}$ & $\begin{array}{l}0.15^{* *} \\
(0.05)\end{array}$ & $\begin{array}{l}0.15^{* *} \\
(0.05)\end{array}$ & $\begin{array}{l}0.15^{* *} \\
(0.05)\end{array}$ \\
\hline $\begin{array}{l}\text { Log Number } \\
\text { Congresswomen }\end{array}$ & $\begin{array}{l}1.08^{*} \\
(0.61)\end{array}$ & $\begin{array}{l}1.01^{*} \\
(0.60)\end{array}$ & $\begin{array}{l}1.03^{*} \\
(0.60)\end{array}$ & $\begin{array}{l}1.30^{*} \\
(0.62)\end{array}$ & $\begin{array}{l}1.09^{*} \\
(0.60)\end{array}$ \\
\hline $\begin{array}{l}\text { Log Black } \\
\text { Population }\end{array}$ & $\begin{array}{l}0.024 \\
(0.02)\end{array}$ & $\begin{array}{l}0.00061 \\
(0.02)\end{array}$ & $\begin{array}{l}0.017 \\
(0.02)\end{array}$ & $\begin{array}{l}0.022 \\
(0.02)\end{array}$ & $\begin{array}{l}0.021 \\
(0.02)\end{array}$ \\
\hline $\begin{array}{l}\text { Log Median } \\
\text { Household Income }\end{array}$ & $\begin{array}{l}0.47 * * * \\
(0.09)\end{array}$ & $\begin{array}{l}0.12 \\
(0.18)\end{array}$ & $\begin{array}{l}0.57 * * * \\
(0.14)\end{array}$ & $\begin{array}{l}0.46 * * * \\
(0.09)\end{array}$ & $\begin{array}{l}0.48 * * * \\
(0.09)\end{array}$ \\
\hline $\begin{array}{l}\text { Log Divorced } \\
\text { Women }\end{array}$ & $\begin{array}{l}-0.071 \\
(0.14)\end{array}$ & & & & \\
\hline $\begin{array}{l}\text { Congresswomen } \mathbf{X} \\
\text { Divorced Women }\end{array}$ & $\begin{array}{l}-0.13 \\
(0.27)\end{array}$ & & & & \\
\hline $\begin{array}{l}\text { Log Wealthy } \\
\text { Women }\end{array}$ & & $\begin{array}{l}0.13^{*} \\
(0.06)\end{array}$ & & & \\
\hline $\begin{array}{l}\text { Congresswomen X } \\
\text { Wealthy Women }\end{array}$ & & $\begin{array}{l}0.029 \\
(0.07)\end{array}$ & & & \\
\hline $\begin{array}{l}\text { Log Girls Under } \\
\text { Five in Poverty }\end{array}$ & & & $\begin{array}{l}0.022 \\
(0.07)\end{array}$ & & \\
\hline $\begin{array}{l}\text { Congresswomen } \mathbf{X} \\
\text { Girls Under } 5 \text { in Poverty }\end{array}$ & & & $\begin{array}{l}0.13 \\
(0.10)\end{array}$ & & \\
\hline $\begin{array}{l}\text { Log Lesbian } \\
\text { Households }\end{array}$ & & & & $\begin{array}{l}0.047 \\
(0.04)\end{array}$ & \\
\hline $\begin{array}{l}\text { Congresswomen } \mathbf{X} \\
\text { Lesbian Households }\end{array}$ & & & & $\begin{array}{l}0.16 \\
(0.10)\end{array}$ & \\
\hline
\end{tabular}


Log Women

$-0.0092$

Veterans

(0.04)

Congresswomen $\mathbf{X}$

$-0.15^{*}$

Women Veterans

(0.09)

\begin{tabular}{llllll} 
Constant & $-7.62^{* *}$ & $-5.13^{*}$ & $-9.32 * *$ & $-9.44 * * *$ & $-8.31^{* *}$ \\
& $(3.15)$ & $(3.08)$ & $(3.24)$ & $(2.88)$ & $(2.79)$ \\
\hline Log Alpha & $-0.70^{* * *}$ & $-0.71^{* * *}$ & $-0.70 * * *$ & $-0.71^{* * *}$ & $-0.71^{* * *}$ \\
Constant & $(0.05)$ & $(0.05)$ & $(0.05)$ & $(0.05)$ & $(0.05)$ \\
\hline $\mathrm{N}$ & 1400 & 1400 & 1400 & 1399 & 1400 \\
Pseudo R-squared & 0.01 & 0.01 & 0.01 & 0.01 & 0.01
\end{tabular}

Note: Variance exceeds the mean indicating negative binomial regression is appropriate. Standard errors in parentheses. ${ }^{*} \mathrm{p}<0.05, * * \mathrm{p}<0.01, * * * \mathrm{p}<0.001$. 


\section{Conclusion:}

\section{Are the women of Congress making a difference in the dynamics of the institution?}

I began this dissertation by discussing the underrepresentation of women in government, but Congress in particular. If it is assumed that political parity is a collective good for the representation of all women in particular and for our society in general, without investigating the link between descriptive and substantive representation, we make an empty promise to ourselves regarding the importance of equality. The representation of women's interests by women in Congress cannot be assumed to improve as more women are elected. Rather, it should be thoroughly investigated, and if congressmen and congresswomen are equally representing the needs of female citizens, this should be pointed out. As other scholars have done before me, we should be curious about the behavioral differences between men and women within the institution, not just because it scrutinizes the implications of parity, but in particular because those differences have implications for how the institution functions and for the representation of all citizens, but of women in particular. The three empirical chapters have explored these implications and will be further discussed in the current chapter.

Why can we expect women to behave differently than men, especially when it comes to working on public policy that specifically concerns the needs of women? First, women serving in both state legislatures and Congress feel a responsibility to specifically represent women (Carroll 2002; Reingold 1992, 2000; Rosenthal 1998; Thomas 1994, 1997). In interviews, female legislators of both parties suggest that women are a unique subset of constituents that have unique policy needs. Some female representatives cite the roles women have because of their gender, such as being wives, mothers, or caregivers in general, as reasons why they need specific attention in representation. Others cite their own societal gender roles as reasons why they are interested in making public policy that helps other women. No matter the party ideology, race, ethnicity, tenure 
in office, or institutional position, women in the U.S. Congress spoke similarly of the responsibility to represent American women (Carroll 2002). Overall, it is clear that because men and women have different societally gendered expectations, women who are elected to office know that representing the needs of their female constituents is important.

Evidence of this representation is seen in the different behaviors of male and female legislators on activities such as the sponsorship and cosponsorship of legislation, roll call voting, and floor speeches (e.g., Swers 2002a \& 2013). When investigating similar behaviors, political scientists have found that female representatives at the state level also prioritize women's issues. They pursue feminist initiatives and legislation, as well as legislation concerning issues of traditional importance to women, such as education, health, and welfare (Berkman and O'Connor 1993; Dodson and Carroll 1991; Dolan and Ford 1995; Saint-Germain 1989; Thomas 1994). Women representatives at the state level are also more likely to see their legislation that advances women's interests passed into law compared to men (Saint-Germain 1989; Thomas 1994). Other findings at the state and national level show that female representatives are able to actively advocate for female constituents by fighting to incorporate more women's interests into committee legislation (Dodson 1998, 2002; Dodson et al. 1995; Gertzog 1995; Norton 2002; Swers 2000, 2002). Also, female committee chairs in state legislatures have reported a more integrative leadership style than their male counterparts, by sharing power with others, collaborating with other chairs, and by sharing strategic information with committee members (Rosenthal 1997, 1998, 2000). Taken together, this brief sample of literature displays the important differences in behavior from men and women at both the state and federal level of government. These findings indicate that women elected to public office have a different representational style, and that when it comes to women's issues, women are better at representing the needs of female constituents (depending 
on the issue and time period) than their male colleagues. I have found further evidence that electing more women to the U.S. House of Representatives has the potential to change the institution itself due to the differences in behavior exhibited by congressmen and congresswomen. This connection between descriptive and substantive representation implies that political parity is a worthy goal. Electing more women to our political institutions has the potential to improve representation of women's interests.

\section{Does electing women to Congress make a difference in the actions that occur on the policies specifically related to women's issues?}

My dissertation investigates gender as a motivating factor for various participatory behaviors of members of the U.S. House of Representatives. The first empirical chapter looks into committee hearings considering women's issue bills, specifically the salient Family and Medical Leave Act and the less salient Commission on the Advancement of Women and Minorities in Science, Engineering, and Technology Development Act. These two laws, having successfully made it through all of the stages of the policy process, show an interest of members of Congress in representing needs that are specific (but not limited to) their female constituents. I was curious to see whether congresswomen participated more than their male colleagues in the hearings considering these two bills. I have found evidence that supports this research question. Women speak out more, ask more questions of witnesses, and speak more (volume) than their male counterparts. Often party was disregarded and being a woman held most of the explanatory power in the statistical models. Even within party, women participated more than men. These findings are important because investigating committee hearings and deliberations of the House is more proximate to the policymaking process than previous research. By looking into the formulation stage of the policy process, I am able to observe important representational behavior that affects the functioning of our democracy. The findings of this chapter also further the connection made in 
previous research between descriptive and substantive representation. Congresswomen clearly take a prominent role in representing women.

In the second empirical chapter, I again turn to committee hearings, this time considering oversight of women's issues. Does the presence of women on committees lead to more oversight of such issues? The evidence suggests that yes, the more women present on a committee, the more oversight hearings that committee holds considering women's issues. Congresswomen are able to spur oversight, an essential part of evaluating public policy. Again, this chapter focuses on behavior that is proximate to the policy process. Considering the findings of these first two empirical chapters, it is clear that electing women to Congress, specifically the House of Representatives, changes deliberations in committee hearings and changes the attention paid to women's issues, most noticeably by ushering women's issue legislation through the formulation stage, as well as by checking up on the implementation of women's issue legislation during the evaluation stage.

Finally, in the third empirical chapter, I turn to bill sponsorship, which can be considered both agenda setting and position taking behavior. Here, I revisit past research that studies gender as a motivating factor for introducing women's issue bills. Previous scholars have, in the past, considered that gender plays an important role in predicting the type of legislators that will introduce women's issue legislation, and have done the important groundwork in adding theoretical importance to the role reelection can play in motivating behavior. Scholars have controlled for reelection worries by including variables that describe a district, such as the number of constituents who are non-white or the median household income. These are valid theoretical controls that allow us to pinpoint what types of districts and therefore what types of legislators may or may not be interested in introducing women's issue bills. Here, my theoretical contribution is to include 
measures available from the Census that detail the types of women living in the district. Perhaps if members of Congress are influenced by both their personal interests and their reelection interests, then we should consider the way gender can affect both of those pieces of the causal puzzle. Therefore, I include measures in the analyses of the members' personal characteristics (most importantly for the inquiry is gender) as well as include the previously mentioned district characteristics, plus measures of the types of women in the district. There are mixed results, but overall I am able to conclude that not only are congresswomen influenced by their gendered identity of being a woman, but they are also tuned into certain populations of their female constituents, which can help them win reelection. Most importantly, when looking within each party, women sponsor more women's issue legislation than their male colleagues. This means that female Democrats introduce more bills than male Democrats and female Republicans introduce more bills than male Republicans. Again, I find clear evidence that women represent women; descriptive and substantive representation are linked.

In this dissertation, I have revisited and reimagined previous scholarship considering women in Congress. In light of these findings, electing more women to Congress will clearly influence the primary federal policymaking institution in our country. Evidence from this dissertation shows that electing women to the House has made a difference in the type of legislation that is introduced, in the kinds of deliberations that take place in committee hearings, and the oversight that checks up on women's interest legislation and programs. Therefore, I believe my dissertation has made a significant contribution to the subfields of both gender and politics and legislative institutions. In the following section, I will revisit the main findings of each of the three empirical chapters. I will also address the questions that have been raised throughout my 
dissertation inquiry and suggest ideas for how political science can address these questions going forward.

\section{Congresswomen as Unique Policymakers and Representatives}

The first exploration in this dissertation for bolstering the connection between descriptive and substantive representation comes from an inquiry into committee hearing deliberations on two important women's issue bills: The Family and Medical Leave Act and the Commission on the Advancement of Women and Minorities in Science, Engineering, and Technology Development Act. By examining committee hearing transcripts, I investigate behaviors that are more proximate to the policymaking process than previous literature. I studied committee hearings to see whether congresswomen present in those hearings outperformed their male colleagues---and overall, they did. Women spoke out more, asked more questions, and spoke more in volume than their male counterparts. These important findings held across party---female Democrats and female Republicans were the most influential in these hearings, thus bolstering the conventional wisdom that women will work more to influence women's issue legislation than men when they are elected to Congress.

Analyses considering committee proceedings of the FMLA found strong results. Across all three models being a congresswoman was a positive and statistically significant indicator of activity. Women spoke out more, asked more questions, and spoke more in volume than their male colleagues. When considering party identification coupled with gender, female Democrats continue to have a positive and statistically significant relationship with a higher frequency of times speaking out in the hearings. These findings clearly indicate that women are the most active in committee hearings considering the FMLA. 
To further this exploration, I included predicted probability analyses and corresponding bar graphs in order to visualize the differences between men and women within and between parties. In comparison to their male counterparts within their own party, Democratic women and Republican women are clearly predicted to speak out more, ask more questions, and speak more words. Even in comparison to chairs, women are impressive participants. Both Democratic and Republican women are predicted to speak out more than the chairs. Plus, chairs are only predicted to ask about one more question than Democratic women and about two more questions than Republican women. This is impressive when considering that both Democratic and Republican men are predicted to ask less than one question. Again, congresswomen are clearly predicted to participate in hearings considering a women's issue than are congressmen.

Turning to the SET commission hearings, I find similar results to the FMLA. Being a congresswoman has a positive and statistically significant relationship with speaking out more and with the volume of words spoken during these hearings. The relationship does not hold for the number of questions, though the coefficient remains positive, which is the expected direction. These findings provide further corroboration for the connection between descriptive and substantive representation. It is evident that when considering women's issues, whether they are salient to voters like the FMLA, or less salient, like the SET commission, congresswomen seek to represent the needs of their female constituents. It isn't a case where women participate more when their constituents are particularly aware of their participation. Rather, women are consistent in their participation, plus their consideration of party seems somewhat secondary. I think this is particularly compelling because I found evidence of female Republicans driving much of the results on the SET commission. In the models where I included dichotomous variables, Republican women speak out more and in volume than the reference category (male Democrats) at a 
statistically significant level. Furthermore, it's not just a story of female Republicans because female Democrats also speak out more than the reference category at a statistically significant level, so women of both parties are participating more than male Democrats. These results, when taken together with the results on the FMLA clearly bolster a link between descriptive and substantive representation.

I again ran predicted probability analyses with bar graphs for visualization based off of the SET commission findings. Again, women in both parties are predicted to speak out more than their male party counterparts in each of the graphs for the three dependent variables. In other words, for all three behaviors, female Democrats outperform male Democrats and female Republicans outperform male Republicans. Only in the model for predicted number of questions asked do Democratic men outperform Republican women. Overall, this chapter provides ample evidence of a connection between descriptive and substantive representation. By electing more women to Congress, more women will become integral committee members who participate more than their male colleagues when considering women's issues. We are faced with evidence that including women in committee deliberations makes a clear impact on the proceedings which are most important in the formulation phase of the policy process.

Before moving on to reviewing the results of chapter 3, it is worth briefly reviewing the robustness check I included considering the propensity of congresswomen to participate more in general than their male colleagues. The investigation proved than in fact, women are more entrepreneurial than their male counterparts on all kinds of legislation, not just women's issues. This means that the criticism regarding women simply being more active still stands. However, I believe this provides us with further evidence that electing more women to Congress will give us a different kind of institution. Yes, women participate more than men in hearings considering 
women's issues, but we expect this to happen if women are going to represent the needs of female constituents better than their male counterparts can. Additionally, if women are more entrepreneurial than men on all issues, the action of electing more women to Congress has the potential to create a more productive environment, producing more active members and thus more legislation. I think that it is very important not to essentialize findings such as these, so that we are simply saying women are different than men. Rather, if female members are acting differently than men, it is important to point this out in relation to the descriptive-substantive connection and the calls for political parity. The findings in this chapter clearly show that women in both parties care enough about both salient and less salient women's issues to participate more than their male colleagues. This bolsters the connection between descriptive and substantive representation because women care enough about their female constituents to use their resources to participate in committee hearings. Furthermore, because women are more entrepreneurial than men, and because they are actively representing the needs of women, electing more women to office has the potential to improve the deliberations within Congress, thus confirming the calls for political parity.

Findings in chapter 3 provide more evidence from the committee structure for the connection between substantive and descriptive representation, this time in the evaluation stage of the policy process. Again, I find evidence that congresswomen as members of committees have a definitive influence on the actions taken by those committees. Here, the more female members serving on a committee, the more oversight hearings considering women's issues occurred over the time period examined. Women do not consistently have access to the highest positions of party leadership. Only recently has Nancy Pelosi (D-CA) been able to alternate between roles as Speaker of the House and Minority Leader, and due to underrepresentation, women still chair many less standing committees compared with men. It is understandable that I find evidence that women 
participate more in hearings related to women's issues, that women are more entrepreneurial in general than their male counterparts, and that the more women members a committee has, the more oversight hearings that committee holds considering legislation and programs related to women's issues. Clearly, women must exercise their influence in other ways besides party and institutional leadership. As the number of oversight hearings increased overtime, and even outpaced the number of legislative hearings, the number of women in the House also grew. Women recognized the importance of oversight in policymaking and took advantage in order to represent the needs of their female constituents. Therefore, I believe that coupled with the evidence from chapter 2 , chapter 3 provides further evidence that women having a seat at the table makes a clear difference within the House. This difference only helps the representation of women.

Turning to the results of chapter 4 , I returned to a focus on the individual legislator as in chapter 2, but moved away from the committee structure. When considering the motivations in individual member behavior, it is important to consider both the extent to which gender motivates behavior on its own, as a fundamental identity (i.e., Swers 2013), and in conjunction with reelection and district motivations. Congresswomen, as all members, are concerned with reelection, making good public policy, and institutional influence. I think that women care about women's issues because they consistently tell us that they do in interviews. Also, we see evidence from both the federal and state level that shows us that women work more on these types of issues than men. Taking these previous findings into account, I wanted to investigate how certain types of women within the district could possibly contribute to a member's propensity to introduce women's issue legislation. When I considered the findings of Palmer and Simon (2006) that members from certain types of congressional districts would have a propensity to introduce more women's issue legislation that others, I also expected women and/or Democrats to sponsor more 
women's issue bills. However, based on my assumptions and findings from previous chapters, I felt like congresswomen may be more in tune to their female constituents, especially if they report thinking about these women when they go to work in Congress.

My reasoning is that perhaps congresswomen who are elected from certain districts with particular female reelection constituencies are more apt to introduce bills related to women's issues than are congresswomen and congressmen from other districts. However, I expect that voters' perceptions of congresswomen allow congresswomen to work on public policies related directly to women's needs and repay them with supportive votes, more so than congressmen. For example, female Republicans would have a much easier time than male Republicans explaining their involvement in working on women's issue legislation, especially if it wasn't explicitly feminist or liberal leaning. After all, women all share common gender roles and societal expectations. Female Republicans could draw on their role as wives, mothers, caregivers, or simply as women to explain involvement in these types of policies benefitting women. Furthermore, I think congresswomen are strategic: they pay attention to the needs of certain female constituencies in their district not only because women's issues interest them, but also because they rely on the voters who are affected by such policy to repay them at the ballot box, and they can do a better job of this than their male counterparts.

The findings from this chapter are mixed. In the preliminary analysis, I find strong statistically significant positive relationships between being a congresswoman and introducing more women's issue bills. These results occur even though there is also a strong relationship between being a Democrat and bill sponsorship. The important takeaway from this analysis is that the results hold across both parties; both Democratic women and Republican women introduce more women's issue bills than their male counterparts. These results hold after I add in the 
variables regarding groups of women within congressional districts. Recall these variables are the number of divorced women, wealthy women, girls living below the poverty line, lesbian households, and female veterans living within the district. In each model where I add in one of these variables, being a congresswoman still maintains a positive and statistically significant relationship with sponsoring women's issue bills. These first two analyses provide clear evidence that women in both parties are acting in accordance with their policy goals and reelection goals. Not only are women introducing more bills related to women's issues, but there is evidence that certain populations of women (wealthy women and lesbian households) spur members to introduce women's issue legislation.

Evidence of the connection between descriptive and substantive representation holds when all five of the female constituency variables are added to the model. The positive and statistically significant relationship between being a congresswoman and introducing women's issue legislation holds. These results are driven by Democratic women, however, when separating out the models for Democrats alone and Republicans alone. Again, these results bolster the assertions made by congresswomen that they seek to represent the needs of women citizens. However, now it is just Democratic women driving the results. This indicates to me that I cannot definitely say that the causal story includes all women. Rather, when the normal district characteristics of median household income and Black population are included, both Democratic and Republican women have equally strong relationships with introducing women's issue legislation compared with men. When I add in the theoretically driven female reelection constituency variables, I initially find support for my predictions: that congresswomen take care to pay attention to these unique subsets of women in order to represent their interests as well as reap the electoral rewards. However, when 
I add in all of the female reelection variables in one model, female Democrats are the ones capitalizing on this relationship with their female constituents, not female Republicans.

Finally, when I investigate the conditional relationship between being a female member and having different female reelection constituencies, only one model (female veterans) produces a result where being a congresswoman maintains a positive and statistically significant relationship with bill sponsorship. Again, the results from the conditional models do not detract from the overall findings. The conditional models are not as explanatory of the relationship between gender and sponsorship as the additive models. Congresswomen clearly introduce more women's issue legislation than their male colleagues in the $111^{\text {th }}, 112^{\text {th }}$, and $113^{\text {th }}$ sessions of Congress. These differences sometimes hold when we compare men and women within the same party, as well. Throughout all of the analyses presented in this chapter, median household income of the district and partisanship of the member had a positive and very often statistically significant relationship with women's issue bill introductions. To me, this warrants further inquiry. As for partisanship, being a Democrat consistently predicts bill introductions. This is expected because Democrats own these types of issues compared with Republicans (Petrocik 1996). Although I find this connection, there is still much evidence in this chapter to show that congresswomen of both parties seek to represent the needs of women by introducing women's issue bills. The change in Republican women's behavior as different control variables are added requires further exploration. Overall, I believe this chapter provide a good preliminary investigation into the role that unique female constituencies play in affecting the behavior of congresswomen. In the next section, I will delve further into a discussion of the limitations of the analyses presented in this dissertation, as well as highlighting the potential extensions of this research.

\section{Limitations \& Potential Extensions of the Research}


There are both chapter-specific limitations, as well as general limitations that I would like to discuss before concluding with a discussion of future research. In chapter 2, I performed a robustness check on my results. The thinking behind this was that because I observe congresswomen participating more so that congressmen, perhaps women simply have the propensity to participate more than men, in general. I chose to investigate this possibility by analyzing the difference between men's and women's entrepreneurship. My results indicated that women do indeed exhibit more behaviors related to entrepreneurship, and thus show higher scores in entrepreneurship than their male colleagues, and at a statistically significant level. However, these results do not put to bed the concerns that women are simply more active than men, in general. In a future project, I would like to address this limitation of the results presented here in the dissertation by either adding another case or adding multiple cases. I can envision this in two ways.

The first way to add another robustness check is to analyze the committee hearing transcripts of a bill from the same time period (1985-1998) that is considered a non-women's issue bill. This is, as discussed below, a tricky job. Topics that are broadly not related to women's issues include macroeconomics, agriculture, the environment, energy, transportation, banking and finance, and defense. I used the women's issue coding I did of the Policy Agendas Project topic and subtopic codes, which was based on the women's groups identified by Swers (2002a), to identify those issue areas that were not coded as women's issues. However, I can think of issues within those broad issue areas that would directly affect women. Even though there is this limitation, which not only plagues my work but the work by others who identify and use women's issues in their scholarship, it is possible to identify a bill that does not directly affect women in a disproportionate way compared to men. Also, it is possible to find a bill that does not have specific 
implications for the advancements of women's rights or equality. In this way, I can identify a bill and use it as a control for the two women's issue bills already investigated. I expect that when I compare the testimony of congresswomen and congressmen, the differences in participation will not hold for the non-women's issue bill.

A second option would be to expand the number of cases used in the analysis. I have analyzed women's issue hearings in this dissertation and I think these data would provide an expansion of the test I conducted in chapter 2. I can identify both women's issue and non-women's issue hearings over time. Then, I can draw a random sample of those hearings, both a random sample of women's issues and a random sample of non-women's issues, and analyze the differences in those hearing deliberations. I could locate the hearing transcripts for those two random samples of hearings and analyze the differences in members' participation. I think that for both of the options I have just described, I expect that in a situation where congresswomen would not be queued to specifically represent the interests of their female constituents, considerations of partisanship will win out. However, when an issue directly affects female constituents personally or considers policy that will directly impact the concerns of women, congresswomen will participate more than their male colleagues.

Returning to the limitations and criticism I, along with other gender and politics scholars, face regarding the identification and coding of women's issues, I realize that this coding is complex. What issues aren't women's issues? I believe that I did as thorough a job as possible in chapters 3 and 4 when I coded for women's issues based on the previous coding schema of Swers (2002a). She identified feminist, anti-feminist, and non-partisan groups to code women's issue policy areas based on the concerns of these groups. Recall in chapter 3, in order to code the hearings as women's issues, I coded the hearings' descriptions for whether or not they covered 
women's issues. I did this with key word coding using STATA syntax to locate hearings with the key words in the description variable provided in the dataset. In order to capture as much legislation as possible, I included every term I could think of that is explicitly, yet uniquely related to women and girls (such as, women, girls, mammography, pregnancy, abortion, etc.). I based the rest of my coding terms on the policy areas identified by the women's groups Swers previously identified. Moving forward with this inquiry, I think that revisiting and possible replacing or adding new groups is warranted. In chapter 4, I coded the topics and subtopics in the Policy Agendas Project as either women's issues or not so that I could similarly identify bills in the Congressional Bills Project dataset, as both datasets use the same topic and subtopic codes.

For both chapters 3 and 4, the coding of women's issues could be improved by adding more specific codes for feminist, anti-feminist, and more general social welfare policies (i.e., Swers 2002a). I can code the hearings for these more specific identifying characteristics by adapting my key word searches and I can code the bills by recoding the subtopic codes. This way, in both analyses, I can disentangle the overlap of partisan and gendered concerns women may have. Clearly pro-life Republican women are not going to act in a way that advances the pro-choice and/or Democratic platform. Party polarization plays such a key role in member behavior in the most recent sessions of Congress, so this coding of the dependent variable is probably most needed for chapter 4 (considering bill sponsorship). Because sponsorship is a clear way to take a position, it is important to consider the nuance of being a Democratic congresswoman and being a Republican congresswoman, especially as behavior shifts as majority and minority party status changes (i.e., Swers 2002a \& 2013), and because party polarization has the potential to color a women's issue. 
Finally, for chapter 4 a concern has been raised to me about the findings reflecting the vulnerability of a member, rather than a member's gender. Perhaps members that pay special attention to the female reelection constituency are not just female members, but rather members who come from electorally vulnerable districts (i.e., Hickey 2014). Scores for the vulnerability of members can easily be added into the analysis and used as a robustness check. The thinking is that a vulnerable member that truly has to fight every two years for reelection because their district is closely split between Democrats and Republicans may turn to the "woman vote" in order to win. I think this is definitely worth addressing. Also, the finding regarding the number of wealthy women in the district predicting women's issue bill sponsorship is particularly concerning. It is concerning because this positive relationship indicates class bias in representation. Well off women in the district may benefit from having a woman represent them in Congress, but poor women may not see the same representational benefits. This is concerning and should be addressed moving forward.

In general, I have two more concerns for all three of the empirical chapters. My first concern is intersectionality. I cannot compare the behaviors of Black, Latina, Asian, or mixed race congresswomen to their white counterparts simply based on the number of women of color present in Congress. I think that this is troubling in and of itself because it reflects the marginalization of women of color in politics. There simply are not enough women of color to compare them in a meaningful way to their white female colleagues. As more women of color are elected to Congress, it will be easier to have more cases in our analyses so that we may begin to make generalizations about the difference in behavior of white congresswomen and congresswomen of color. I also think that we as scholars need to make more of an effort to increase the number of cases in our analyses so that we can reach back in time to longitudinally address these intersectionality effects. For 
example, in the above discussion concerning the limitations and expansion of chapter 2, I proposed using a sample of hearing transcripts to increase the $\mathrm{N}$ and to meaningfully compare women's issue hearings and non-women's issue hearings. By doing so, it is possible that I may add observations of congresswomen of color in order to assess the potential effects of intersectionality. Moving forward, I believe all gender and politics scholars should consider the importance of intersectionality because the experience of white women are not the experiences of Black women, nor are those the experiences of Latinas, and so on.

My second and final concern is the time dimension. I do not directly test the implications of increased party polarization over time. In chapter 2, the time period examined is 1985-1998, before extreme party polarization. Chapter 4 takes place in 2005-2014, when extreme polarization was apparent. Going forward, this is a major concern because the findings of chapter 2 are not generalizable to our current time period. This can easily be updated with the options for improvement I have discussed above. For chapter 4, I think that the more specific women's issue coding scheme can disentangle partisanship and gender in order to pinpoint the specific differences between the type of women's issue legislation female Democrats would sponsor and the type of women's issue legislation female Republicans would sponsor. Perhaps polarization plays such a huge role that women behave no differently than their male counterparts and women's issue sponsorship belongs solely to Democrats. Again, these possibilities definitely warrant investigation.

\section{Future Research \& Conclusions}

Many ideas for avenues of future research presented themselves to me while working on this dissertation. Substantive and descriptive representation are linked in my mind because in all of the venues I tested, women behave differently than men in order to represent the unique needs 
of women. However, gender alone cannot be considered the definitive motivating factor in spurring behavior of members of Congress. As evidenced by the empirical and statistical work in chapters 2,3 , and 4 the intersectionality of many factors helps describe the behavior of individual members of the House, namely: partisanship, majority/minority position, time and context, committee membership, and finally district factors including median household income, the number of wealthy women residing in a district, and the number of lesbian households in a district. All of these factors should spur political scientists to explore the reasons why these factors play a consistent role in affecting a member's behavior, in conjunction with our solid knowledge of reelection concerns, concerns for making good public policy, and concerns for institutional positions of power.

One of the reasons I found listed in the previous literature for why we might expect congresswomen to act differently than congressmen revolves around the idea of consensus building traits (i.e., Volden \& Wiseman 2009, 2014; Volden, Wiseman, \& Wittmer 2013). These traits are listed as a reason for why women are more effective, and effectiveness is part of the reason why I think women are more entrepreneurial. However, I think I believe this because I hear women in Congress, especially female Senators, talking about this publicly quite frequently. For example, in 2013 media coverage gave much credit to female Senators for leading a bipartisan charge to compromise and end a government shutdown ${ }^{47}$. Even in post-2016 election coverage, news outlets were discussing the role of women in government. An article in the New York Times quotes Senator Kirsten Gillibrand (D-NY), "Women tend to be less partisan, more collaborative, listen better, find common ground. Every time I've had a bill that's important to me, I've had

\footnotetext{
${ }^{47}$ For example: http://www.nytimes.com/2013/10/15/us/senate-women-lead-in-effort-to-find-accord.html and http://swampland.time.com/2013/10/16/women-are-the-only-adults-left-in-washington/
} 
strong Republican women helping me pass it." ${ }^{48}$ Media coverage also tends to highlight examples of comradery among congressional women. Do we have any empirical evidence that any of this actually produces more consensus building and problem solving among congresswomen compared to congressmen?

Lawless and Theriault (2016) find evidence that congresswomen value collegiality more than congressmen. For example, women are more likely to participate in the Secret Santa gift exchange and Seersucker Thursday than their male colleagues. However, when it comes to other more substantive examples of consensus building and problem solving, the results show no difference between men and women. The authors argue, "Members who are 'problem solvers' should be more inclined than those who are not to vote with colleagues across the aisle on procedural votes, since doing so moves the legislative process along and generates a more efficient, collaborative route to a final passage vote (regardless of the fact that those final passage votes are likely to be highly partisan)" (2016, 9). Little evidence is found between men and women when considering the procedural votes they cast. The authors also investigate amendment offering in the Senate, making an argument that if a senator displays a consistent pattern in offering amendments, they are a "problem creator" because they seek to stall the legislative process. If women are truly more collegial than men, we should see less "problem creators" among women than we do among men. There is no evidence of this theory either. Men and women act largely the same. So, while women participate more than men in fun, collegial activities, when it comes to institutional examples of consensus building and problem solving, women are no different than men. Kanthak \& Krause (2012) also investigate coordination, and show us that simply increasing the number of women elected to legislatures does not does not directly lead to coordination, thus the diversity

\footnotetext{
${ }^{48} \mathrm{https} / / /$ www.nytimes.com/2016/11/10/upshot/women-actually-do-govern-differently.html?_r=0
} 
paradox. As more women are elected, we may actually observe less coordination among women. Taking together the findings discussed above, there are troubling implications for the link between descriptive and substantive representation as more women are elected to Congress.

These scholarly efforts begin to answer questions raised about collegiality and consensus building, but I think we can do more to investigate the claims made by female senators like Kirsten Gillibrand. First, we should look to committee hearings. As I discussed in chapter 4 and found evidence for in chapter 3, there are examples where women in committee are able to spur consideration of certain types of issues, often women's issues that would not be considered if only men were present. Is there a way to further analyze committee hearings in order to assess women's consensus building traits? It would likely need to include text-based analysis of hearing transcripts, but I think it is worth the effort to examine if women really do exhibit more consensus building traits than men, especially if we are going to predicate other theories (effectiveness, entrepreneurship, etc.) on this idea. Another avenue is to ask female legislators about consensus building to see if they truly have multiple examples of different ways they are able to build consensus among themselves in comparison to men. The other troubling factor in this line of scholarly inquiry is the idea of consensus building traits. What are those traits? Why do we expect women to have them in comparison to men? Can we measure those traits? Can we expect certain kinds of members to have them, besides women?

Secondly, is talking about consensus building just a different way to claim-credit and advertise? It is easy enough to get the annual congressional women's softball game covered by the media, but lately women seem to highlight their collegiality and their work ethic whenever they get the chance. As I mentioned above, women highlighted their role in a successful bipartisan effort to end the government shutdown in 2013. Female Senators claimed credit for showing up 
when the men didn't in the blizzard of January $2016 .{ }^{49}$ Plus, it is easy to advertise themselves by taking pictures together often and capitalizing on their minority status, or tokenism. Women in the Senate are especially covered with their semi-regular dinner meetings. Further inquiry into why women would be interested in highlighting their collegiality, even if there is no empirical evidence to back up its transference into legislative activities, is warranted in light of public opinion data. The Pew Research Center finds that women respondents more than men believe that women in elected office are better than men at working out compromises, being honest and ethical, working to improve quality of life for Americans, standing up for beliefs despite political pressure, and being persuasive ${ }^{50}$. Even if we don't find empirical evidence to back up these activities and attributes, congresswomen may simply highlight such characteristics in order to reap electoral rewards from female constituents. They can play on those female voters' perceptions of women in government in order to seek reelection.

In a similar vein, we hear the "working twice as hard to be considered just as good" refrain from activists seeking gender and racial equality. If we care about investigating the potential affects gender parity will have on Congress as an institution, do we have evidence in the entrepreneurship and effectiveness work that shows women are working harder? I think my results indicate yes, but is this "twice as hard" reason why they are doing it? Similarly, and relating back to the previous paragraph's discussion, perhaps women are more collegial, or at least claim to be more collegial than men due to underrepresentation. Of course, there is no way to test if this behavior is due to women's small numbers because we don't have a situation of true parity in

\footnotetext{
${ }^{49}$ The Google search results make it clear, this was extensively covered by media: https:/www.google.com/search?client=safari\&rls=en\&q=women+show+up+to+congress + in + blizzard\&ie $=\mathrm{UTF}-8 \& \mathrm{oe}=\mathrm{UTF}-8$

${ }^{50} \mathrm{http}$ ://www.pewresearch.org/fact-tank/2016/05/19/americans-views-of-women-as-political-leadersdiffer-by-gender/
} 
Congress with which to compare. If women exhibit just as much party polarization as men do as evidenced by more recent scholarship on the more recent congressional sessions, then I tentatively expect women to decrease in entrepreneurship as more women are elected to office. If we reach parity, women will have significantly changed the institution and the way it functions. Will there be a need for them to be any more collegial, cooperative, effective, or entrepreneurial than their male colleagues anymore? Perhaps these behaviors will only stay if there truly is a gendered difference in a member's approach to representation and policymaking. Otherwise, women may hold onto this rhetoric in order to capitalize on women voters' perceptions.

My last suggestion for political science research is to consider the causal mechanism that underpins my entire dissertation and the entire gender and politics subfield: why do we expect women and men to behave differently? As I discussed above, we have many reasons to believe that men and women behave differently based on previous findings. Some of these findings are related to women's behavior as candidates, as members of state legislatures, or as members of Congress. We also look to public opinion and political behavior literature to draw on general trends in women's thinking or political participation at the mass level, rather than the elite level. However, I'm not sure we are doing a good enough job at pinpointing the specific sociological and/or psychological reasons why women behave differently than men. We certainly attempt to test for these gendered differences, and we observe them. Many of us say that gender is an essential characteristic and that is why it is important to investigate the role it may have in decision making, representation, participation, campaigning, etc. The problem is that ideology or religiosity or morality are also essential characteristics that help people identify themselves. These characteristics define how people view themselves in the world. Even where a person lives or 
comes from and what kind of job they have helps construct a person's self-perception. Why is gender any different?

This is why concerns have been raised in social sciences of investigating the intersectionality of these identifying characteristics. The group of "women" is so broad and includes so many different types of women it seems short-sighted to make generalizations about women versus men. But we do observe clear trends in our society, and specifically for the purpose of this dissertation within Congress, even within parties, of women participating more than men when it comes to working on women's issues. Gender is something that colors all aspects of our lives as humans. "Most people...voluntarily go along with their society's prescriptions for those of their gender status, because the norms and expectations get built into their sense of worth and identity as [the way we] think, the way we see and hear and speak, the way we fantasy, and the way we feel" (Lorber 1994). Yes, not all women are the same in America, and not all women in Congress are the same. However, women are connected by gender as a process, as stratification, and as structure (Lorber 1994). So, when political scientists argue that they expect to observe differences in men and women due to fundamental gender characteristics, they are expecting political participation and behavior to be colored by gender because all behavior---and arguably all things in society---are colored by gender. Everyone "does gender" all day every day, so it is important to study the differences between the men and women who serve us in government. As political and social scientists, I think we need to figure out why gender is such a crucial determining factor in behavior of individuals because our government is clearly effected by it.

In sum, my dissertation has considered one main question: does electing women to Congress make a difference in the actions that occur on the policies specifically related to women's issues? Overall, I think the results displayed here answer this question with "yes." In committee 
hearings considering the FMLA and the SET commission, women in both parties out performed their male colleagues in the number of times speaking out, the volume of words spoken, and the number of questions asked. When investigating the affect women have on the oversight of women's interest legislation and programs, I find that the more women present on a committee, the more oversight hearings that committee will hold. Finally, congresswomen in both the Democratic and Republican parties introduce more women's interest legislation than their male counterparts. However, only two out of five measures of female constituencies affect member's propensity to introduce women's issue bills, and these measures do not condition behavior for congresswomen. Not all of my hypotheses were confirmed, but overall I think my dissertation research shows that electing women to Congress makes a clear difference in the functioning of the institution. This allows us to make an argument for the connection between descriptive and substantive representation because the differences in men and women were observed using cases where members were working on women's issues. This highlights congresswomen's ability to represent the unique needs of women better than their male colleagues. Therefore, these results also legitimize arguments for political parity. 


\section{Bibliography}

Aberbach, Joel. 2002. "What's Happened to the Watchful Eye." Congress and the Presidency 29: 323.

Adler, E. Scott. 2002. Why Congressional Reforms Fail: Reelection and the House Committee System. University of Chicago Press.

Adler, E. Scott, and John D. Wilkerson. 2013. Congress and the Politics of Problem Solving. Cambridge University Press.

Arnold, Douglas. 1990. The Logic of Congressional Action. New Haven, CT: Yale University Press. Barrett, Edith. 1995. "The Policy Priorities of African American Women in State Legislatures." Legislative Studies Quarterly, no. 20: 223-47.

Berkman, Michael B., and Robert E. O’Connor. 1993. “Do Women Legislators Matter? Female Legislators and State Abortion Policy.” American Politics Quarterly, no. 21: 102-24.

Bratton, Kathleen A. 2005. “Critical Mass Theory Revisited: The Behavior and Success of Token Women in State Legislatures.” Politics \& Gender 1 (1): 97-125.

Burrell, Barbara C. 1994. A Woman's Place Is in the House: Campaigning for Congress in the Feminist Era. Ann Arbor: University of Michigan Press.

Carroll, Royce, Jeffrey B. Lewis, James Lo, Keith T. Poole, and Howard Rosenthal. 2009. "Measuring Bias and Uncertainty in DW-NOMINATE Ideal Point Estimates via the Parametric Bootstrap." Political Analysis 17: 261-227.

Carroll, Susan J. 2002. “Representing Women: Congresswomen's Perceptions of Their Representational Role." In Women Transforming Congress, edited by Cindy Simon Rosenthal. Norman: University of Oklahoma Press. 
CAWP: Center for American Women and Politics (Eagleton Institute of Politics at Rutgers, the State University of New Jersey). Women in the U.S. Congress 2016 Fact Sheet, http://www.cawp.rutgers.edu/current-numbers

Clarke, Kevin. 2005. “The Phantom Menace: Omitted Variable Bias in Econometric Research.” Conflict Management and Peace Science 22 (4): 341-52.

Darcy, Robert. 1996. "Women in the State Legislative Power Structure: Committee Chairs." Social Science Quarterly, 888-98.

Darling, Marsha L. 1998. “African-American Women in State Elective Office in the South.” In Women and Elective Office: Past, Present, and Future, edited by Sue Thomas and Clyde Wilcox. New York, NY: Oxford University Press.

Dawson, Michael. 1994. Behind the Mule: Race and Class in African-American Politics. Princeton, NJ: Princeton University Press.

Deering, Christopher J., and Steven S. Smith. 1997. Committees in congress. SAGE.

Diamond, Irene. 1977. Sex Roles in the State House. New Haven, CT: Yale University Press.

Dodson, Debra L. 1998. “Representing Women’s Interests in the U.S. House of Representatives.” In Women and Elective Office: Past, Present, and Future, edited by Sue Thomas and Clyde Wilcox. New York: Oxford University Press.

—. 2002. "Representation, Gender and Reproductive Rights in the U.S. Congress." In Women Transforming Congress, edited by Cindy Simon Rosenthal. Norman: University of Oklahoma Press.

Dodson, Debra L., and Susan J. Carroll. 1991. Reshaping the Agenda: Women in State Legislatures. New Brunswick, NJ: Center for American Women and Politics, Rutgers, The State University of New Jersey. 
Dodson, Debra L., Susan J. Carroll, Ruth B. Mandel, Katherine E. Kleeman, Ronnee Schreiber, and Debra Liebowitz. 1995. Voices, Views, Votes: The Impact of Women in the 103rd Congress. New Brunswick, NJ: Center for American Women and Politics, Rutgers, The State University of New Jersey.

Dolan, Julie. 1997. “Support for Women’s Interests in the 103rd Congress: The Distinct Impact of Congressional Women.” Women and Politics, no. 18: 81-94.

Dolan, Kathleen, and Lynn Ford. 1995. "Women In The State Legislatures: Feminist Identity and Legislative Behaviors.” American Politics Quarterly, no. 23: 96-108.

Duerst-Lahti, Georgia. 2002a. “Governing Institutions, Ideologies, and Gender: Towards the Possibility of Equal Political Representation.” Sex Roles 47 (7/8): 371-88.

_. 2002b. "Knowing Congress as a Gendered Institution: Manliness and the Implications of Women in Congress." In Women Transforming Congress, edited by Cindy Simon Rosenthal. Norman: University of Oklahoma Press.

Duerst-Lahti, Georgia, and Rita Mae Kelly. 1995. “On Governance, Leadership, and Gender.” In Gender Power, Leadership, and Governance, edited by Georgia Duerst-Lahti and Rita Mae Kelly. Ann Arbor: University of Michigan Press.

Esterling, Kevin M. 2007. "Buying Expertise: Campaign Contributions and Attention to Policy Analysis in Congressional Committee.” American Political Science Review 101 (1): 93-109. Fenno, Richard F. 1973. Congressmen in Committees. Little Brown.

- 1978. Home Style: House Members in Their Districts. Boston, MA: Little Brown.

Fiorina, Morris P., Samuel J. Abrams, and Jeremy C. Pope. 2011. Culture Wars? The Myth of a Polarized America. 3rd ed. New York, NY: Longman. 
Foerstel, Karen, and Herbert Foerstel. 1996. Climbing the Hill: Gender Conflict in Congress.

Westport, CT: Praeger Publishers.

Frankovic, Kathleen A. 1977. "Sex and Voting in the U.S. House of Representatives, 1961-1975.” American Politics Quarterly, no. 5: 315-30.

Gehlen, Freida. 1977. "Women Members of Congress: A Distinctive Role." In A Portraito F Marginality: The Political Behavior of the American Woman, edited by Marianne Githens and Jewell Prestage. New York, NY: McKay Co.

Gertzog, Irwin. 1995. Congressional Women: Their Recruitment, Integration, and Behavior. 2nd ed. Westport, CT: Praeger Publishers.

Hall, Richard. 1996. Participation in Congress. New Haven, CT: Yale University Press.

Hickey, Patrick T. 2014. "Beyond Pivotal Politics: Constituencies, Electoral Incentives, and Veto Override Attempts in the House." Presidential Studies Quarterly 44, no. 4: 577-601.

Jenkins, Shannon. 2007. ““'A Woman’s Work Is Never Done? Fund-Raising Perception and Effort among Female State Legislative Candidates." Political Research Quarterly 60 (2): 230-39.

Jeydel, Alana, and Andrew Taylor. 2003. "Are Women Legislators Less Effective? Evidence from the U.S. House in the 103rd-105th Congress." Political Research Quarterly 56 (1): 19-27.

Kanter, Rosabeth Moss. 1977. "Some Effects of Proportions on Group Life: Skewed Sex Ratios and Responses to Token Women.” American Journal of Sociology, no. 82: 965-890.

Karpowitz, Christopher F., and Tali Mendelberg. 2014. Silent Sex : Gender, Deliberation, and Institutions. Princeton, NJ: Princeton University Press.

Kathak, Kristin, and George A. Krause. 2012. The Diversity Paradox: Political Parties, Legislatures, and the Organizational Foundations of Representation in America. New York, NY: Oxford University Press. 
Kathlene, Lyn. 1994. "Power and Influence in State Legislative Policymaking: The Interaction of Gender and Position in Committee Hearing Debate." American Political Science Review 88 (3): $560-76$.

—. 1995. “Alternative Views of Crime: Legislative Policymaking in Gendered Terms.” Journal of Politics, no. 57: 696-723.

Kelly, Rita Mae, and Georgia Duerst-Lahti. 1995. "The Study of Gender Power and Its Link to Governance and Leadership.” In Gender Power, Leadership, and Governance, edited by Georgia Duerst-Lahti and Kelly, Rita Mae. Ann Arbor: University of Michigan Press.

Kenney, Sally. 1996. "New Research on Gendered Political Institutions.” Political Research Quarterly, no. 49: 445-66.

King, David C. 1997. Turf Wars: How Congressional Committees Claim Jurisdiction. Chicago: University of Chicago Press.

Kingdon, John W. 1989. Congressmen's Voting Decisions. Ann Arbor: University of Michigan Press. Kirkpatrick, Jeane. 1974. Political Woman. New York, NY: Basic Books.

Lawless, Jennifer L., and Kathryn Pearson. 2008. “The Primary Reason for Women’s Underrepresentation? Reevaluating the Conventional Wisdom.” Journal of Politics 70 (1): 6782.

Lawless, Jennifer L., and Sean M. Theriault. 2016. "Sex, Bipartisanship, and Collaboration in the U.S. Congress.” Political Parity.

Leader, Shelah Gilbert. 1977. "The Policy Impact of Elected Women Officials.” In The Impact of the Electoral Process, edited by Joseph Cooper and Louis Maisel. Beverly Hills, CA: Sage Publications. 
Levy, Dena, Charles Tien, and Rachelle Aved. 2001. 'Do Differences Matter? Women Members of Congress and the Hyde Amendment." Women and Politics 23 (1): 105-27.

Lorber, Judith. 1994. Paradoxes of Gender. New Haven, CT: Yale University Press.

MacDonald, Jason A., and Robert McGrath. 2016. "Retrospective Congressional Oversight and Legislative Influence over the Bureaucracy." Legislative Studies Quarterly 41 (4): 899-934.

MacDonald, Jason A., and Erin E. O’Brien. 2010. “Quasi-Experimental Design, Constituency, and Advancing Women's Interests: Reexamining the Influence of Gender on Substantive Representation." Political Research Quarterly 64 (2): 472-86.

Mansbridge, Jane. 1999. "Should Blacks Represent Blacks and Women Represent Women?

A Contingent 'Yes."' The Journal of Politics 61 (3): 628-57.

—. 2003. "Rethinking Representation." American Political Science Review 97 (4): 515-28.

Mayhew, David R. 1975. Congress: The Electoral Connection. New Haven, CT: Yale University Press.

McGrath, Robert. 2013. “Congressional Oversight Hearings and Policy Control.” Legislative Studies Quarterly 38 (August): 349-76.

Milyo, Jeffrey, and Samantha Schosberg. 2000. "Gender Bias and Selection Bias in House Elections." Public Choice, no. 105: 41-59.

Norton, Noelle H. 1995. “Women, It's Not Enough to Be Elected: Committee Position Makes a Difference." In Gender Power, Leadership, and Governance, edited by Georgia Duerst-Lahti and Rita Mae Kelly. Ann Arbor: University of Michigan Press.

_. 1999. "Committee Influence Over Controversial Policy: The Reproductive Policy Case." Policy Studies Journal, no. 27: 203-16. 
—. 2002. "Transforming Congress From The Inside: Women in Committee." In Women Transforming Congress, edited by Cindy Simon Rosenthal. Norman: University of Oklahoma Press.

Palmer, Barbara, and Dennis Simon. 2008. Breaking the Political Glass Ceiling: Women and Congressional Elections. Second. New York, NY: Routledge.

Petrocik, John R. 1996. “Issue Ownership in Presidential Elections, with a 1980 Case Study.” American Journal of Political Science 40 (3): 825-50.

Phillips, Anne. 1995. The Politics of Presence. New York, NY: Oxford University Press.

Pitkin, Hannah. 1967. The Concept of Representation. Los Angeles, CA: The University of California Press.

Poggione, Sarah. 2004. "Exploring Gender Differences in State Legislators' Policy Preferences." Political Research Quarterly 57 (2): 305-14.

Poole, Keith T., and Howard Rosenthal. 2007. Ideology and Congress. New Brunswick, NJ: Transaction Publishers.

Popkin, Samuel L. 1994. The Reasoning Voter: Communication and Persuasion in Presidential Campaigns. Chicago: University of Chicago Press.

Reingold, Beth. 1992. "Concepts of Representation Among Female and Male State Legislators." Legislative Studies Quarterly, no. 27: 509-37.

-2000. Representing Women: Sex, Gender, and Legislative Behavior in Arizona and California. University of North Carolina Press.

Rinehart, Sue Tolleson. 1991. "Do Women Leaders Make a Difference? Substance, Style and Perceptions." In Gender and Policymaking: Studies of Women in Office, edited by Debra L. 
Dodson, 93-102. New Brunswick, NJ: Center for American Women and Politics, Rutgers, The State University of New Jersey.

Rosenthal, Cindy Simon. 1997. “A View of Their Own: Women’s Committee Leadership Styles and State Legislatures.” Policy Studies Journal, no. 25: 585-600.

. 1998. When Women Lead: Integrative Leadership in State Legislatures. New York, NY:

Oxford University Press.

—. 2000. “Gender Styles in State Legislative Committees: Raising Their Voices in Resolving Conflict." Women and Politics, no. 21: 21-45.

Saint-Germain, Michelle. 1989. "Does Their Difference Make a Difference? The Impact of Women on Public Policy in the Arizona Legislature.” Social Science Quarterly, no. 70: 956-68.

Sanbonmatsu, Kira. 2006. Where Women Run: Gender and Party in the American States. Ann Arbor: University of Michigan Press.

Sapiro, Virginia. 1981. "Research Frontier Essay: When Are Interests Interesting? The Problem of Political Representation of Women.” American Political Science Review, no. 75: 701-16.

Sides, John. 2006. “The Origins of Campaign Agendas.” British Journal of Political Science 36: 40736.

Swain, Carol M. 1993. Black Faces, Black Interests. Cambridge, MA: Harvard University Press.

Swers, Michele L. 1998. “Are Congresswomen More Likely to Vote for Women's Issue Bills Than Their Male Colleagues?” Legislative Studies Quarterly, no. 23: 435-48.

—. 2001. "Understanding the Policy Impact of Electing Women: Evidence from Research on Congress and State Legislature.” PS, Political Science \& Politics 34 (2): 217-20.

_. 2002a. The Difference Women Make: The Policy Impact of Women in Congress. Chicago: University of Chicago Press. 
_ 2002b. "Transforming the Agenda? Analyzing Gender Differences in Women's Issue Bill

Sponsorship." In Women Transforming Congress, edited by Cindy Simon Rosenthal. Norman:

University of Oklahoma Press.

. 2013. Women in the Club: Gender and Policy Making in the Senate. Chicago: University of Chicago Press.

—. 2016a. "Pursuing Women's Interests in Partisan Times: Explaining Gender Differences in Legislative Activity on Health, Education, and Women's Health Issues.” Journal of Women, Politics \& Policy 37 (3): 249-73.

—. 2016b. "Women \& Legislative Leadership in the U.S. Congress: Representing Women's Interests in Partisan Times." Daedalus 145 (3): 44-56.

Tamerius, Karin L. 1995. “Sex, Gender, and Leadership in the Representation of Women.” In Gender Power, Leadership, and Governance, edited by Georgia Duerst-Lahti and Rita Mae Kelly. Ann Arbor: University of Michigan Press.

Tatalovich, Raymond, and David Schier. 1993. "The Persistence of Ideological Cleavage in Voting on Abortion Legislation in the House of Representatives, 1973-1988." American Politics Quarterly, no. 21: 125-39.

Thomas, Sue. 1991. "The Impact of Women on State Legislative Policies.” The Journal of Politics 53 (4): 958-76.

—. 1994. How Women Legislate. New York, NY: Oxford University Press.

—. 1997. "Why Gender Matters: The Perceptions of Women Officeholders." Women and Politics, no. 17: 27-53.

Thomas, Sue, and Susan Welch. 1991. "The Impact of Gender on Activities and Priorities of State Legislators." Western Political Quarterly, no. 44: 445-56. 
Vega, Arturo, and Juanita M. Firestone. 1995. “The Effects of Gender on Congressional

Behavior and the Substantive Representation of Women." Legislative Studies Quarterly, no. 20: $213-22$.

Volden, Craig, and Alan E. Wiseman. 2009. "Legislative Effectiveness in Congress." The Ohio State University. Manuscript.

- 2014. Legislative Effectiveness in the United States Congress: The Lawmakers. Cambridge University Press.

Volden, Craig, Alan E. Wiseman, and Dana E. Wittmer. 2013. "When Are Women More Effective Lawmakers Than Men.” American Journal of Political Science 57 (2): 326-41.

Walsh, Katherine Cramer. 2002. "Resonating To Be Heard: Gendered Debate On The Floor Of The House.” In Women Transforming Congress. Norman: University of Oklahoma Press.

Wawro, Gregory. 2000. Legislative Entrepreneurship in the U.S. House of Representatives. Ann Arbor: University of Michigan Press.

Welch, Susan. 1985. “Are Women More Liberal than Men in the U.S. Congress?” Legislative Studies Quarterly, no. 10: 125-34.

Wolbrecht, Christina. 2002. "Female Legislators and the Women's Rights Agenda.” In Women Transforming Congress, edited by Cindy Simon Rosenthal. Norman: University of Oklahoma Press. 


\section{Appendix}

\section{CHAPTER 2}

\section{Data sources:}

- FMLA and SET commission analyses

- Committee Hearing Transcripts for FMLA and SET commission. Available online from HathiTrust Digital Library. Call numbers found with ProQuest Congressional.

- Congressional district characteristics. Datasets available online from E. Scott Adler, University of Colorado, Boulder

- Member party identification \& ideology. Available online from Lewis, Poole, and Rosenthal's voteview.com

- Member personal characteristics. Available online from the US House of Representatives Archives

- LE analysis

- Entrepreneurship data is made publicly available from Gregory Wawro's website: http://www.columbia.edu/ gjw10/research.html. Accessed May 18,2015

○ Committee membership data from Stewart \& Woon (2005): http://web.mit.edu/17.251/www/data_page.html

- Chamber and party median of Nominate scores: http://voteview.com/pmediant.htm

- African American: http://www.senate.gov/CRSReports/crspublish.cfm?pid=\%270E $\% 2 \mathrm{C} * \mathrm{PLW} \% 3 \mathrm{C} \% 20 \mathrm{P} \% 20 \% 20 \% 0 \mathrm{~A}$

○ Latino: http://history.house.gov/People/Search?filter $=11$

○ Speaker of the House: http://history.house.gov/People/Office/Speakers/ 


\section{Table A2.1: Data Sources, Definitions, and Descriptive Statistics}

\begin{tabular}{|c|c|c|c|}
\hline \multicolumn{4}{|l|}{$\underline{\text { FMLA }}$} \\
\hline Independent Variables & Description & Mean & Std. Dev. \\
\hline Congresswomen & Equals " 1 ” for woman, " 0 ” for man & .10 & .30 \\
\hline Party Identification & Equals " 1 " for Democrats, " 0 " for Republicans & .61 & .49 \\
\hline South & $\begin{array}{l}\text { Equals " } 1 \text { " if a member represents a district located } \\
\text { in the South, " } 0 \text { " for all others }\end{array}$ & .15 & .35 \\
\hline Chair & $\begin{array}{l}\text { Equals " } 1 \text { " if a member chairs the committee, } \\
\text { " } 0 \text { " for all others }\end{array}$ & .03 & .18 \\
\hline Hearing ID & $\begin{array}{l}\text { Each hearing numbered } 0-8 \text {, used to construct dummy } \\
\text { variables of hearings } 1-8 \text {, with a hearing left out as } \\
\text { reference category }\end{array}$ & 4.14 & 2.62 \\
\hline Log Urban Population & $\begin{array}{l}\text { Log of total number of people living in urban areas within } \\
\text { a member's district }\end{array}$ & 12.80 & .40 \\
\hline Log Median Family Income & Log of median family income within a member's district & 9.95 & .31 \\
\hline Log Black Population & $\begin{array}{l}\text { Log of total number of African Americans within a } \\
\text { member's district }\end{array}$ & 10 & 1.69 \\
\hline
\end{tabular}

$\underline{\text { SET commission }}$ 


\begin{tabular}{|c|c|c|c|}
\hline Independent Variables & Description & Mean & Std. Dev. \\
\hline Congresswomen & Equals " 1 " for woman, "0" for man & .16 & .36 \\
\hline Party Identification & Equals “1” for Democrats, “0” for Republicans & .44 & .50 \\
\hline African American & Equals " 1 " for African American, " 0 " for all others & .06 & .24 \\
\hline South & $\begin{array}{l}\text { Equals " } 1 \text { " if a member represents a district located } \\
\text { in the South, "0" for all others }\end{array}$ & .27 & .44 \\
\hline Chair & $\begin{array}{l}\text { Equals " } 1 \text { " if a member chairs the committee, } \\
\text { "0" for all others }\end{array}$ & .02 & .15 \\
\hline Number of Terms & Number of terms an individual member has served & 4 & 3.22 \\
\hline Hearing ID & $\begin{array}{l}\text { Each hearing numbered } 0-8 \text {, used to construct dummy } \\
\text { variables of hearings } 1-8 \text {, with a hearing left out as } \\
\text { reference category }\end{array}$ & 1.03 & .77 \\
\hline Log Urban Population & $\begin{array}{l}\text { Log of total number of people living in urban areas within } \\
\text { a member's district }\end{array}$ & 12.73 & .64 \\
\hline Log Median Family Income & Log of median family income within a member's district & 10.34 & .39 \\
\hline Log Black Population & $\begin{array}{l}\text { Log of total number of African Americans within a } \\
\text { member's district }\end{array}$ & 10.18 & 1.38 \\
\hline \multicolumn{4}{|l|}{ Legislative Entrepreneurship } \\
\hline Independent Variables & Description & Mean & Std. Dev. \\
\hline Congresswomen & Equals "1" for woman, "0" for man & .06 & .23 \\
\hline
\end{tabular}


Majority Party

1st Dimension

DW-NOMINATE

2nd Dimension

DW-NOMINATE

Distance from

Chamber Median

Distance from

Majority Party Median

African American

Latino

Speaker

Chair

Ranking Member

Seniority

Prestigious Committee
Equals "1" for Democrats, "0" for Republicans

Ideology Score, Pool \& Rosenthal (2007)

Ideology Score, Pool \& Rosenthal (2007)

Constructed from Chamber Median,

Pool \& Rosenthal (2007)

Constructed from Majority Party Median,

Pool \& Rosenthal (2007)

Equals "1" for African American, "0" for all others

Equals "1" for Latino/a, "0" for all others

Equals "1" for Speaker of the House, "0" for all others

Equals " 1 " if a member is a chair of a committee,

" 0 " for all others

Equals "1" if a member is a ranking member of a committee, "0" for all others

Number of Terms Served by a member

Equals "1" if Appropriations, Budget, Rules, Ways \& Means, " 0 " for all others; Stewart \& Woon (2005) 
Table A2.2: Full Model FMLA with Gender Interactions: Interaction Term

\begin{tabular}{|c|c|c|c|}
\hline & $\begin{array}{l}\text { Number Times } \\
\text { Testifying }\end{array}$ & $\begin{array}{l}\text { Number of } \\
\text { Words }\end{array}$ & $\begin{array}{l}\text { Number of } \\
\text { Questions }\end{array}$ \\
\hline Congresswoman & $\begin{array}{l}2.14^{*} \\
(1.05)\end{array}$ & $\begin{array}{l}2.24 \\
(1.61)\end{array}$ & $\begin{array}{l}1.36 \\
(1.17)\end{array}$ \\
\hline Party Identification & $\begin{array}{l}0.36 \\
(0.56)\end{array}$ & $\begin{array}{l}0.21 \\
(0.80)\end{array}$ & $\begin{array}{l}0.25 \\
(0.59)\end{array}$ \\
\hline $\begin{array}{l}\text { Congresswoman } \mathbf{X} \\
\text { Party Identification }\end{array}$ & $\begin{array}{l}-0.31 \\
(1.42)\end{array}$ & $\begin{array}{l}-0.68 \\
(2.13)\end{array}$ & $\begin{array}{l}-2.62 \\
(1.65)\end{array}$ \\
\hline African American & $\begin{array}{l}2.21 * * \\
(0.94)\end{array}$ & $\begin{array}{l}1.55 \\
(1.35)\end{array}$ & $\begin{array}{l}2.68^{*} \\
(1.16)\end{array}$ \\
\hline South & $\begin{array}{l}1.31^{*} \\
(0.69)\end{array}$ & $\begin{array}{l}1.03 \\
(1.07)\end{array}$ & $\begin{array}{l}0.60 \\
(0.74)\end{array}$ \\
\hline Chair & $\begin{array}{l}1.53 \\
(1.23)\end{array}$ & $\begin{array}{l}1.57 \\
(1.86)\end{array}$ & $\begin{array}{l}2.23^{*} \\
(1.34)\end{array}$ \\
\hline Number of Terms & $\begin{array}{l}-0.028 \\
(0.07)\end{array}$ & $\begin{array}{l}-0.014 \\
(0.11)\end{array}$ & $\begin{array}{l}-0.13 \\
(0.09)\end{array}$ \\
\hline Hearing 1 & $\begin{array}{l}-0.51 \\
(0.74)\end{array}$ & $\begin{array}{l}-1.02 \\
(1.11)\end{array}$ & $\begin{array}{l}-0.55 \\
(0.86)\end{array}$ \\
\hline Hearing 2 & $\begin{array}{l}1.08 \\
(0.66)\end{array}$ & $\begin{array}{l}0.50 \\
(0.99)\end{array}$ & $\begin{array}{l}0.59 \\
(0.76)\end{array}$ \\
\hline Hearing 3 & $\begin{array}{l}0.52 \\
(0.67)\end{array}$ & $\begin{array}{l}0.025 \\
(1.00)\end{array}$ & $\begin{array}{l}0.49 \\
(0.77)\end{array}$ \\
\hline Hearing 4 & $\begin{array}{l}1.20 * \\
(0.67)\end{array}$ & $\begin{array}{l}0.99 \\
(1.04)\end{array}$ & $\begin{array}{l}1.01 \\
(0.77)\end{array}$ \\
\hline Hearing 5 & $\begin{array}{l}-0.081 \\
(0.85)\end{array}$ & $\begin{array}{l}0.081 \\
(1.27)\end{array}$ & $\begin{array}{l}-0.32 \\
(0.97)\end{array}$ \\
\hline Hearing 6 & $\begin{array}{l}0 \\
(.)\end{array}$ & $\begin{array}{l}0 \\
(.)\end{array}$ & $\begin{array}{l}0 \\
(.)\end{array}$ \\
\hline Hearing 7 & $\begin{array}{l}0 \\
(.)\end{array}$ & $\begin{array}{l}0 \\
(.)\end{array}$ & $\begin{array}{l}0 \\
(.)\end{array}$ \\
\hline Hearing 8 & $\begin{array}{l}0 \\
(.)\end{array}$ & $\begin{array}{l}0 \\
(.)\end{array}$ & $\begin{array}{l}0 \\
(.)\end{array}$ \\
\hline Log Urban & 0.38 & 0.79 & 0.26 \\
\hline
\end{tabular}




\begin{tabular}{llll} 
Population & $(0.85)$ & $(1.27)$ & $(0.87)$ \\
& $2.64^{*}$ & 2.53 & $3.33^{*}$ \\
Log Median & $(1.34)$ & $(2.01)$ & $(1.65)$ \\
Family Income & & & \\
& -0.082 & -0.021 & -0.11 \\
Log Black & $(0.20)$ & $(0.30)$ & $(0.21)$ \\
Population & & & \\
Constant & $-30.4^{* *}$ & $-30.9^{*}$ & $-35.2^{* *}$ \\
& $(12.12)$ & $(17.89)$ & $(14.64)$ \\
Log Alpha & $1.88^{* * *}$ & $2.73^{* * *}$ & $2.04^{* * *}$ \\
Constant & $(0.15)$ & $(0.13)$ & $(0.19)$ \\
& & & 207 \\
\hline N & 207 & 0.01 & 0.04 \\
Pseudo R-squared & 0.04 & &
\end{tabular}

Note: Variance exceeds the mean indicating negative binomial regression is appropriate. Standard errors in parentheses. ${ }^{*} \mathrm{p}<0.05, * * \mathrm{p}<0.01, * * * \mathrm{p}<0.001$.

Table A2.3: Full Model FMLA with Gender Interactions: Dummy Interactions

\begin{tabular}{|c|c|c|c|}
\hline & $\begin{array}{l}\text { Number Times } \\
\text { Testifying }\end{array}$ & $\begin{array}{l}\text { Number of } \\
\text { Words }\end{array}$ & $\begin{array}{l}\text { Number of } \\
\text { Questions }\end{array}$ \\
\hline Female Democrat & $\begin{array}{l}1.83^{*} \\
(0.99)\end{array}$ & $\begin{array}{l}1.55 \\
(1.42)\end{array}$ & $\begin{array}{l}-1.26 \\
(1.20)\end{array}$ \\
\hline Female Republican & $\begin{array}{l}1.78 \\
(1.09)\end{array}$ & $\begin{array}{l}2.03 \\
(1.62)\end{array}$ & $\begin{array}{l}1.11 \\
(1.23)\end{array}$ \\
\hline Male Republican & $\begin{array}{l}-0.36 \\
(0.56)\end{array}$ & $\begin{array}{l}-0.21 \\
(0.80)\end{array}$ & $\begin{array}{l}-0.25 \\
(0.59)\end{array}$ \\
\hline African American & $\begin{array}{l}2.21 * * \\
(0.94)\end{array}$ & $\begin{array}{l}1.55 \\
(1.35)\end{array}$ & $\begin{array}{l}2.68^{*} \\
(1.16)\end{array}$ \\
\hline South & $\begin{array}{l}1.31 * \\
(0.69)\end{array}$ & $\begin{array}{l}1.03 \\
(1.07)\end{array}$ & $\begin{array}{l}0.60 \\
(0.74)\end{array}$ \\
\hline Chair & $\begin{array}{l}1.53 \\
(1.23)\end{array}$ & $\begin{array}{l}1.57 \\
(1.86)\end{array}$ & $\begin{array}{l}2.23 * \\
(1.34)\end{array}$ \\
\hline Number of Terms & $\begin{array}{l}-0.028 \\
(0.07)\end{array}$ & $\begin{array}{l}-0.014 \\
(0.11)\end{array}$ & $\begin{array}{l}-0.13 \\
(0.09)\end{array}$ \\
\hline Hearing 1 & $\begin{array}{l}-0.51 \\
(0.74)\end{array}$ & $\begin{array}{l}-1.02 \\
(1.11)\end{array}$ & $\begin{array}{l}-0.55 \\
(0.86)\end{array}$ \\
\hline
\end{tabular}




\begin{tabular}{|c|c|c|c|}
\hline Hearing 2 & $\begin{array}{l}1.08 \\
(0.66)\end{array}$ & $\begin{array}{l}0.50 \\
(0.99)\end{array}$ & $\begin{array}{l}0.59 \\
(0.76)\end{array}$ \\
\hline Hearing 3 & $\begin{array}{l}0.52 \\
(0.67)\end{array}$ & $\begin{array}{l}0.025 \\
(1.00)\end{array}$ & $\begin{array}{l}0.49 \\
(0.77)\end{array}$ \\
\hline Hearing 4 & $\begin{array}{l}1.20^{*} \\
(0.67)\end{array}$ & $\begin{array}{l}0.99 \\
(1.04)\end{array}$ & $\begin{array}{l}1.01 \\
(0.77)\end{array}$ \\
\hline Hearing 5 & $\begin{array}{l}-0.081 \\
(0.85)\end{array}$ & $\begin{array}{l}0.081 \\
(1.27)\end{array}$ & $\begin{array}{l}-0.32 \\
(0.97)\end{array}$ \\
\hline Hearing 6 & $\begin{array}{l}0 \\
(.)\end{array}$ & $\begin{array}{l}0 \\
(.)\end{array}$ & $\begin{array}{l}0 \\
(.)\end{array}$ \\
\hline Hearing 7 & $\begin{array}{l}0 \\
(.)\end{array}$ & $\begin{array}{l}0 \\
(.)\end{array}$ & $\begin{array}{l}0 \\
(.)\end{array}$ \\
\hline Hearing 8 & $\begin{array}{l}0 \\
(.)\end{array}$ & $\begin{array}{l}0 \\
(.)\end{array}$ & $\begin{array}{l}0 \\
(.)\end{array}$ \\
\hline $\begin{array}{l}\text { Log Urban } \\
\text { Population }\end{array}$ & $\begin{array}{l}0.38 \\
(0.85)\end{array}$ & $\begin{array}{l}0.79 \\
(1.27)\end{array}$ & $\begin{array}{l}0.26 \\
(0.87)\end{array}$ \\
\hline $\begin{array}{l}\text { Log Median } \\
\text { Family Income }\end{array}$ & $\begin{array}{l}2.64^{*} \\
(1.34)\end{array}$ & $\begin{array}{l}2.53 \\
(2.01)\end{array}$ & $\begin{array}{l}3.33^{*} \\
(1.65)\end{array}$ \\
\hline $\begin{array}{l}\text { Log Black } \\
\text { Population }\end{array}$ & $\begin{array}{l}-0.082 \\
(0.20)\end{array}$ & $\begin{array}{l}-0.021 \\
(0.30)\end{array}$ & $\begin{array}{l}-0.11 \\
(0.21)\end{array}$ \\
\hline Constant & $\begin{array}{l}-30.1 * * \\
(11.97)\end{array}$ & $\begin{array}{l}-30.7 * \\
(17.71)\end{array}$ & $\begin{array}{l}-35.0 * * \\
(14.51)\end{array}$ \\
\hline $\begin{array}{l}\text { Log Alpha } \\
\text { Constant }\end{array}$ & $\begin{array}{l}1.88 * * * \\
(0.15)\end{array}$ & $\begin{array}{l}2.73 * * * \\
(0.13)\end{array}$ & $\begin{array}{l}2.04 * * * \\
(0.19)\end{array}$ \\
\hline $\begin{array}{l}\mathrm{N} \\
\text { Pseudo R-squared }\end{array}$ & $\begin{array}{l}207 \\
0.04\end{array}$ & $\begin{array}{l}207 \\
0.01\end{array}$ & $\begin{array}{l}207 \\
0.04\end{array}$ \\
\hline
\end{tabular}

Note: Variance exceeds the mean indicating negative binomial regression is appropriate.

Standard errors in parentheses. ${ }^{*} \mathrm{p}<0.05, * * \mathrm{p}<0.01, * * * \mathrm{p}<0.001$.

Table A2.4: Full Model SET Commission with Gender Interactions: Interaction Term

\begin{tabular}{llll}
\hline & $\begin{array}{l}\text { Number Times } \\
\text { Testifying }\end{array}$ & $\begin{array}{l}\text { Number of } \\
\text { Words }\end{array}$ & $\begin{array}{l}\text { Number of } \\
\text { Questions }\end{array}$ \\
\hline Congresswoman & $4.52 * *$ & $7.62 *$ & 3.09
\end{tabular}


(1.92)

Party Identification

Congresswoman $\mathbf{X}$

Party Identification

African American

South

Chair

Number of Terms

Hearing 1

Hearing 2

Log Urban

Population

Log Median

Family Income

Log Black

Population

Constant

Log Alpha

Constant
0.60

(0.87)

$-1.63$

(2.05)

$-19.1$

(25.41)

$-0.88$

(1.24)

0.94

(3.20)

$-0.089$

(0.18)

1.22

(1.88)

1.29

(2.04)

$-1.33$

(1.03)

$-2.37$

(2.60)

0.12

(0.39)

38.7

(25.14)

$2.33 * * *$

(0.27)
(3.57)

1.10

(1.61)

$-2.89$

(3.93)

$-24.9$

(33.19)

$-4.20$

(2.75)

\subsection{9}

(7.35)

$-0.38$

(0.46)

\subsection{7}

(3.63)

4.51

(3.90)

$-3.23$

(2.14)

$-5.90$

(4.66)

0.51

(0.73)

98.7*

(51.36)

$3.46^{* * *}$

(0.23)

0.02

\begin{tabular}{llll}
\hline $\mathrm{N}$ & 134 & 134 & 134 \\
Pseudo R-squared & 0.07 & 0.02 & 0.11 \\
\hline
\end{tabular}

(3.14)

2.13

(1.76)

1.04

$-23.6$

(24.68)

$-0.23$

(2.15)

$-21.3$

(82.75)

$-0.016$

(0.30)

$-4.44$

(4.42)

$-0.0056$

(4.19)

$-2.48$

(1.87)

0.99

(5.43)

0.40

(0.73)

14.5

$(47.05)$

$2.92 * * *$

(0.46)

Note: Variance exceeds the mean indicating negative binomial regression is appropriate. Standard errors in parentheses. ${ }^{*} \mathrm{p}<0.05, * * \mathrm{p}<0.01, * * * \mathrm{p}<0.001$.

Table A2.5: Full Model SET Commission with Gender Interactions: Dummy Interactions 


\begin{tabular}{|c|c|c|c|}
\hline & $\begin{array}{l}\text { Number Times } \\
\text { Testifying }\end{array}$ & $\begin{array}{l}\text { Number of } \\
\text { Words }\end{array}$ & $\begin{array}{l}\text { Number of } \\
\text { Questions }\end{array}$ \\
\hline Female Democrat & $\begin{array}{l}2.89^{*} \\
(1.57)\end{array}$ & $\begin{array}{l}4.72 \\
(3.55)\end{array}$ & $\begin{array}{l}4.12 \\
(3.27)\end{array}$ \\
\hline Female Republican & $\begin{array}{l}3.92 * \\
(2.06)\end{array}$ & $\begin{array}{l}6.51^{*} \\
(3.75)\end{array}$ & $\begin{array}{l}0.96 \\
(3.47)\end{array}$ \\
\hline Male Republican & $\begin{array}{l}-0.60 \\
(0.87)\end{array}$ & $\begin{array}{l}-1.10 \\
(1.61)\end{array}$ & $\begin{array}{l}-2.13 \\
(1.76)\end{array}$ \\
\hline African American & $\begin{array}{l}-19.2 \\
(26.42)\end{array}$ & $\begin{array}{l}-24.7 \\
(31.53)\end{array}$ & $\begin{array}{l}-25.0 \\
(49.88)\end{array}$ \\
\hline South & $\begin{array}{l}-0.88 \\
(1.24)\end{array}$ & $\begin{array}{l}-4.20 \\
(2.75)\end{array}$ & $\begin{array}{l}-0.23 \\
(2.15)\end{array}$ \\
\hline Chair & $\begin{array}{l}0.94 \\
(3.20)\end{array}$ & $\begin{array}{l}3.39 \\
(7.35)\end{array}$ & $\begin{array}{l}-22.5 \\
(15.52)\end{array}$ \\
\hline Number of Terms & $\begin{array}{l}-0.089 \\
(0.18)\end{array}$ & $\begin{array}{l}-0.38 \\
(0.46)\end{array}$ & $\begin{array}{l}-0.016 \\
(0.30)\end{array}$ \\
\hline Hearing 1 & $\begin{array}{l}1.22 \\
(1.88)\end{array}$ & $\begin{array}{l}3.67 \\
(3.63)\end{array}$ & $\begin{array}{l}-4.44 \\
(4.42)\end{array}$ \\
\hline Hearing 2 & $\begin{array}{l}1.29 \\
(2.04)\end{array}$ & $\begin{array}{l}4.51 \\
(3.90)\end{array}$ & $\begin{array}{l}-0.0056 \\
(4.19)\end{array}$ \\
\hline $\begin{array}{l}\text { Log Urban } \\
\text { Population }\end{array}$ & $\begin{array}{l}-1.33 \\
(1.03)\end{array}$ & $\begin{array}{l}-3.23 \\
(2.14)\end{array}$ & $\begin{array}{l}-2.48 \\
(1.87)\end{array}$ \\
\hline $\begin{array}{l}\text { Log Median } \\
\text { Family Income }\end{array}$ & $\begin{array}{l}-2.37 \\
(2.60)\end{array}$ & $\begin{array}{l}-5.90 \\
(4.66)\end{array}$ & $\begin{array}{l}0.99 \\
(5.43)\end{array}$ \\
\hline $\begin{array}{l}\text { Log Black } \\
\text { Population }\end{array}$ & $\begin{array}{l}0.12 \\
(0.39)\end{array}$ & $\begin{array}{l}0.51 \\
(0.73)\end{array}$ & $\begin{array}{l}0.40 \\
(0.73)\end{array}$ \\
\hline Constant & $\begin{array}{l}39.3 \\
(25.04)\end{array}$ & $\begin{array}{l}99.8^{*} \\
(51.57)\end{array}$ & $\begin{array}{l}16.6 \\
(46.69)\end{array}$ \\
\hline $\begin{array}{l}\text { Log Alpha } \\
\text { Constant }\end{array}$ & $\begin{array}{l}2.33 * * * \\
(0.27)\end{array}$ & $\begin{array}{l}3.46 * * * \\
(0.23)\end{array}$ & $\begin{array}{l}2.92 * * * \\
(0.46)\end{array}$ \\
\hline $\begin{array}{l}\mathrm{N} \\
\text { Pseudo R-squared }\end{array}$ & $\begin{array}{l}134 \\
0.07\end{array}$ & $\begin{array}{l}134 \\
0.02\end{array}$ & $\begin{array}{l}134 \\
0.11\end{array}$ \\
\hline
\end{tabular}

Note: Variance exceeds the mean indicating negative binomial regression is appropriate. Standard errors in parentheses. ${ }^{*} \mathrm{p}<0.05,{ }^{*} * \mathrm{p}<0.01, * * * \mathrm{p}<0.001$. 
Table A2.6: Full OLS Models of Legislative Entrepreneurship in the U.S. House, 94th-103rd Congresses

\begin{tabular}{|c|c|c|c|c|}
\hline & (1) & (2) & (3) & (4) \\
\hline Congresswoman & $\begin{array}{l}12.1 * * * \\
(2.53)\end{array}$ & $\begin{array}{l}10.5^{* * *} \\
(2.53)\end{array}$ & $\begin{array}{l}8.56 * * * \\
(2.51)\end{array}$ & $\begin{array}{l}8.32 * * * \\
(2.51)\end{array}$ \\
\hline $\begin{array}{l}\text { Majority Party } \\
\text { Member }\end{array}$ & $\begin{array}{l}15.7 * * * \\
(1.66)\end{array}$ & $\begin{array}{l}4.14 * \\
(2.36)\end{array}$ & & \\
\hline $\begin{array}{l}\text { 1st Dimension } \\
\text { DW-NOMINATE }\end{array}$ & & & $\begin{array}{l}-28.7 * * * \\
(2.29)\end{array}$ & $\begin{array}{l}-26.4 * * * \\
(4.29)\end{array}$ \\
\hline $\begin{array}{l}\text { 2nd Dimension } \\
\text { DW-NOMINATE }\end{array}$ & & & $\begin{array}{l}-7.06 * * * \\
(1.36)\end{array}$ & $\begin{array}{l}-7.89 * * * \\
(1.36)\end{array}$ \\
\hline $\begin{array}{l}\text { Distance from } \\
\text { Chamber Median }\end{array}$ & $\begin{array}{l}8.83 * \\
(3.99)\end{array}$ & & $\begin{array}{l}8.15^{*} \\
(3.97)\end{array}$ & \\
\hline $\begin{array}{l}\text { Distance from } \\
\text { Majority Party } \\
\text { Median }\end{array}$ & & $\begin{array}{l}-19.4 * * * \\
(4.16)\end{array}$ & & $\begin{array}{l}0.62 \\
(5.32)\end{array}$ \\
\hline $\begin{array}{l}\text { African } \\
\text { American }\end{array}$ & $\begin{array}{l}1.15 \\
(2.90)\end{array}$ & $\begin{array}{l}6.14^{*} \\
(2.78)\end{array}$ & $\begin{array}{l}-9.71 * * * \\
(3.09)\end{array}$ & $\begin{array}{l}-7.38^{*} \\
(3.32)\end{array}$ \\
\hline Latino & $\begin{array}{l}-3.22 \\
(3.96)\end{array}$ & $\begin{array}{l}-2.43 \\
(3.93)\end{array}$ & $\begin{array}{l}-6.12 \\
(3.96)\end{array}$ & $\begin{array}{l}-5.04 \\
(3.97)\end{array}$ \\
\hline Speaker & $\begin{array}{l}-20.1 \\
(21.85)\end{array}$ & $\begin{array}{l}-24.7 \\
(21.83)\end{array}$ & $\begin{array}{l}-27.0 \\
(21.58)\end{array}$ & $\begin{array}{l}-26.3 \\
(21.59)\end{array}$ \\
\hline Chair & $\begin{array}{l}18.1 * * * \\
(2.96)\end{array}$ & $\begin{array}{l}17.8^{* * *} \\
(2.95)\end{array}$ & $\begin{array}{l}18.4 * * * \\
(2.93)\end{array}$ & $\begin{array}{l}18.7 * * * \\
(2.93)\end{array}$ \\
\hline Ranking & $\begin{array}{l}-4.45 \\
(2.91)\end{array}$ & $\begin{array}{l}-6.61^{*} \\
(2.90)\end{array}$ & $\begin{array}{l}-7.12 * * \\
(2.81)\end{array}$ & $\begin{array}{l}-7.50 * * \\
(2.81)\end{array}$ \\
\hline Seniority & $\begin{array}{l}1.36^{* * *} \\
(0.18)\end{array}$ & $\begin{array}{l}1.38^{* * *} \\
(0.18)\end{array}$ & $\begin{array}{l}1.32 * * * \\
(0.18)\end{array}$ & $\begin{array}{l}1.35^{* * *} \\
(0.18)\end{array}$ \\
\hline $\begin{array}{l}\text { Prestigious } \\
\text { Committee }\end{array}$ & $\begin{array}{l}7.23 * * * \\
(1.35)\end{array}$ & $\begin{array}{l}6.63 * * * \\
(1.36)\end{array}$ & $\begin{array}{l}6.99 * * * \\
(1.34)\end{array}$ & $\begin{array}{l}7.06 * * * \\
(1.34)\end{array}$ \\
\hline $94^{\text {th }}$ & $\begin{array}{l}-17.4 * * * \\
(2.57)\end{array}$ & $\begin{array}{l}-18.6 * * * \\
(2.57)\end{array}$ & $\begin{array}{l}-18.5 * * * \\
(2.54)\end{array}$ & $\begin{array}{l}-18.7 * * * \\
(2.54)\end{array}$ \\
\hline
\end{tabular}




\begin{tabular}{|c|c|c|c|c|}
\hline $95^{\text {th }}$ & $\begin{array}{l}-20.0^{* * * *} \\
(2.58)\end{array}$ & $\begin{array}{l}-21.2 * * * \\
(2.57)\end{array}$ & $\begin{array}{l}-21.0 * * * \\
(2.54)\end{array}$ & $\begin{array}{l}-21.2 * * * \\
(2.54)\end{array}$ \\
\hline $96^{\text {th }}$ & $\begin{array}{l}-5.81^{*} \\
(2.57)\end{array}$ & $\begin{array}{l}-6.83^{* *} \\
(2.57)\end{array}$ & $\begin{array}{l}-6.67 * * \\
(2.54)\end{array}$ & $\begin{array}{l}-6.86^{* *} \\
(2.54)\end{array}$ \\
\hline $97^{\text {th }}$ & $\begin{array}{c}5.79 * \\
(2.57)\end{array}$ & $\begin{array}{l}4.83^{*} \\
(2.57)\end{array}$ & $\begin{array}{l}4.84 * \\
(2.54)\end{array}$ & $\begin{array}{l}4.61 * \\
(2.54)\end{array}$ \\
\hline $98^{\text {th }}$ & $\begin{array}{l}9.30 * * * \\
(2.57)\end{array}$ & $\begin{array}{l}8.50 * * * \\
(2.56)\end{array}$ & $\begin{array}{l}8.63 * * * \\
(2.53)\end{array}$ & $\begin{array}{l}8.47 * * * \\
(2.54)\end{array}$ \\
\hline $99^{\text {th }}$ & $\begin{array}{l}4.12 \\
(2.56)\end{array}$ & $\begin{array}{l}3.41 \\
(2.56)\end{array}$ & $\begin{array}{l}3.40 \\
(2.53)\end{array}$ & $\begin{array}{l}3.29 \\
(2.53)\end{array}$ \\
\hline $100^{\text {th }}$ & $\begin{array}{l}8.03 * * * \\
(2.56)\end{array}$ & $\begin{array}{l}7.28 * * \\
(2.56)\end{array}$ & $\begin{array}{l}7.33 * * \\
(2.53)\end{array}$ & $\begin{array}{l}7.19 * * \\
(2.53)\end{array}$ \\
\hline $101^{\mathrm{st}}$ & $\begin{array}{l}11.6^{* * *} \\
(2.56)\end{array}$ & $\begin{array}{l}11.0 * * * \\
(2.56)\end{array}$ & $\begin{array}{c}11.0 * * * \\
(2.53)\end{array}$ & $\begin{array}{l}10.8 * * * \\
(2.53)\end{array}$ \\
\hline $102^{\text {nd }}$ & $\begin{array}{l}14.9 * * * \\
(2.57)\end{array}$ & $\begin{array}{l}14.5^{* * *} \\
(2.56)\end{array}$ & $\begin{array}{c}14.4^{* * * *} \\
(2.53)\end{array}$ & $\begin{array}{l}14.3 * * * \\
(2.53)\end{array}$ \\
\hline Constant & $\begin{array}{l}39.4 * * * \\
(2.81)\end{array}$ & $\begin{array}{l}56.3^{* * * *} \\
(3.43)\end{array}$ & $\begin{array}{l}49.0 * * * \\
(2.31)\end{array}$ & $\begin{array}{l}51.3 * * * \\
(2.73)\end{array}$ \\
\hline $\mathrm{N}$ & 4370 & 4370 & 4370 & 4370 \\
\hline $\mathrm{R}-\mathrm{sq}$ & .1692 & .1724 & .1905 & .1897 \\
\hline F-Statistic & $46.63 * * *$ & $47.69 * * *$ & $51.16 * * *$ & $50.90 * * *$ \\
\hline
\end{tabular}

Table A2.7: Full OLS Models, Including Interaction Terms, of Legislative Entrepreneurship in the U.S. House, 94th-103rd Congresses

Congresswoman

Majority

Party

Congresswoman $\mathbf{X}$

Majority Party Member

Distance from
(1)

(2)

$\begin{array}{ll}16.9^{* * *} & 12.8^{* *} \\ (4.19) & (4.18)\end{array}$

$16.4 * * *$

4.49*

(1.72)

(2.41)

$-7.45$

$-3.64$

(5.25)

(5.23) 
Chamber Median

Distance from

Majority Party Median

African American

Latino

Speaker

Chair

Ranking Member

Seniority

Prestigious

Committee

$94^{\text {th }}$ Congress

$95^{\text {th }}$ Congress

$96^{\text {th }}$ Congress

$97^{\text {th }}$ Congress

$98^{\text {th }}$ Congress

$99^{\text {th }}$ Congress

$100^{\text {th }}$ Congress

$101^{\text {st }}$ Congress
$-19.1 * * *$

(4.18)

1.19

$6.22 *$

(2.90)

(2.78)

$-3.47$

$-2.53$

(3.96)

(3.94)

$-20.0$

$-24.7$

(21.85)

(21.83)

$17.9^{* * *}$

$17.7 * * *$

(2.96)

(2.95)

$-4.11$

$-6.44 *$

(2.92)

(2.91)

$1.35^{* * *}$

(0.18)

$1.38^{* * *}$

(0.18)

$7.22 * * *$

(1.35)

$6.63 * * *$

(1.36)

$-17.5^{* * *}$

$-18.7 * * *$

(2.57)

$-20.0^{* * *}$

$-21.3 * * *$

(2.57)

$-5.87 *$

$-6.86^{* *}$

(2.57)

(2.57)

$5.72 *$

(2.58)

$4.79 *$

(2.57)

$9.21 * * *$

$8.45^{* * *}$

(2.57)

(2.56)

4.02

3.35

(2.56)

(2.56)

$7.93 * * *$

(2.56)

$7.23 * *$

(2.56)

$11.5^{* * *}$

$10.9^{* * *}$

(2.56)

(2.56) 


\begin{tabular}{lll}
$102^{\text {nd }}$ Congress & $\begin{array}{ll}14.9^{* * *} \\
(2.57)\end{array}$ & $\begin{array}{l}14.5^{* * *} \\
(2.56)\end{array}$ \\
& & \\
Constant & $38.9^{* * *}$ & $56.0^{* * *}$ \\
& $(2.83)$ & $(3.45)$ \\
\hline $\mathrm{N}$ & 4370 & 4370 \\
$\mathrm{R}-$ sq & .1696 & .1725 \\
F-Statistic & $44.41^{* * *}$ & $45.33^{* * *}$
\end{tabular}

NOTES: Standard errors are in parentheses. ${ }^{*} \mathrm{p}<0.05,{ }^{* *} \mathrm{p}<0.01,{ }^{* * *} \mathrm{p}<0.001$ 
Table A2.8: Legislative Entrepreneurship per Congressional Session, 94th - 103rd

\begin{tabular}{|c|c|c|c|c|c|c|c|c|c|c|}
\hline & 94th & 95 th & 96th & 97 th & 98th & 99th & 100 th & $101 \mathrm{st}$ & $102 \mathrm{nd}$ & 103rd \\
\hline Congresswoman & $\begin{array}{l}-1.03 \\
(3.78)\end{array}$ & $\begin{array}{c}3.11 \\
(5.55)\end{array}$ & $\begin{array}{l}4.27 \\
(7.67)\end{array}$ & $\begin{array}{l}3.20 \\
(9.53)\end{array}$ & $\begin{array}{l}16.4^{*} \\
(8.44)\end{array}$ & $\begin{array}{l}19.8^{*} \\
(9.52)\end{array}$ & $\begin{array}{l}9.86 \\
(8.98)\end{array}$ & $\begin{array}{l}11.1 \\
(8.68)\end{array}$ & $\begin{array}{l}24.8 * * \\
(9.18)\end{array}$ & $\begin{array}{l}12.6^{*} \\
(5.81)\end{array}$ \\
\hline $\begin{array}{l}\text { Majority Party } \\
\text { Member }\end{array}$ & $\begin{array}{l}1.72 \\
(2.87)\end{array}$ & $\begin{array}{l}-7.67 * \\
(3.96)\end{array}$ & $\begin{array}{l}5.23 \\
(5.33)\end{array}$ & $\begin{array}{l}-6.82 \\
(7.65)\end{array}$ & $\begin{array}{l}-12.3 \\
(7.61)\end{array}$ & $\begin{array}{l}3.51 \\
(10.12)\end{array}$ & $\begin{array}{l}2.22 \\
(9.26)\end{array}$ & $\begin{array}{l}-0.36 \\
(9.78)\end{array}$ & $\begin{array}{c}27.8 * * \\
(10.96)\end{array}$ & $\begin{array}{l}16.7 * \\
(9.50)\end{array}$ \\
\hline $\begin{array}{l}\text { Distance from } \\
\text { Chamber Median }\end{array}$ & $\begin{array}{l}35.2 * * * \\
(8.90)\end{array}$ & $\begin{array}{l}64.7 * * * \\
(12.61)\end{array}$ & $\begin{array}{l}45.9 * * \\
(15.39)\end{array}$ & $\begin{array}{l}13.8 \\
(16.14)\end{array}$ & $\begin{array}{l}59.8 * * * \\
(18.76)\end{array}$ & $\begin{array}{l}37.7 * \\
(20.44)\end{array}$ & $\begin{array}{l}31.3 \\
(20.12)\end{array}$ & $\begin{array}{l}83.8 * * * \\
(22.06)\end{array}$ & $\begin{array}{l}37.4 \\
(24.16)\end{array}$ & $\begin{array}{l}17.8 \\
(20.52)\end{array}$ \\
\hline $\begin{array}{l}\text { Distance from } \\
\text { Majority Party } \\
\text { Median }\end{array}$ & $\begin{array}{l}-30.4 * * * \\
(8.40)\end{array}$ & $\begin{array}{l}-68.8 * * * \\
(12.22)\end{array}$ & $\begin{aligned} * & -53.4 * * * \\
& (14.97)\end{aligned}$ & $\begin{array}{r}-43.9 * * \\
(16.80)\end{array}$ & $\begin{array}{l}-107.4^{* * *} \\
(19.11)\end{array}$ & $\begin{array}{l}-40.0 * \\
(22.28)\end{array}$ & $\begin{array}{l}-51.3 * * \\
(21.43)\end{array}$ & $\begin{array}{l}-79.3 * * * \\
(24.25)\end{array}$ & $\begin{array}{l}-4.65 \\
(27.06)\end{array}$ & $\begin{array}{l}7.82 \\
(23.20)\end{array}$ \\
\hline African American & $\begin{array}{l}6.02 \\
(4.35)\end{array}$ & $\begin{array}{l}11.0^{*} \\
(6.39)\end{array}$ & $\begin{array}{l}-17.6^{*} \\
(8.23)\end{array}$ & $\begin{array}{c}-4.06 \\
(10.92)\end{array}$ & $\begin{array}{l}6.20 \\
(9.74)\end{array}$ & $\begin{array}{l}-2.43 \\
(11.43)\end{array}$ & $\begin{array}{l}15.0 \\
(10.08)\end{array}$ & $\begin{array}{l}-0.97 \\
(10.27)\end{array}$ & $\begin{array}{l}-15.5 \\
(10.50)\end{array}$ & $\begin{array}{c}-3.54 \\
(7.09)\end{array}$ \\
\hline Latino & $\begin{array}{l}-9.29 \\
(7.06)\end{array}$ & $\begin{array}{c}-19.8 * \\
(9.21)\end{array}$ & $\begin{array}{c}-14.7 \\
(12.37)\end{array}$ & $\begin{array}{l}-5.70 \\
(15.73)\end{array}$ & $\begin{array}{l}-21.1^{*} \\
(12.43)\end{array}$ & $\begin{array}{l}-10.5 \\
(13.71)\end{array}$ & $\begin{array}{l}19.4 \\
(12.87)\end{array}$ & $\begin{array}{l}11.8 \\
(13.40)\end{array}$ & $\begin{array}{l}-20.1 \\
(14.45)\end{array}$ & $\begin{array}{l}-1.73 \\
(9.21)\end{array}$ \\
\hline Speaker & $\begin{array}{l}0 \\
(.)\end{array}$ & $\begin{array}{l}0 \\
(.)\end{array}$ & $\begin{array}{l}0 \\
(.)\end{array}$ & $\begin{array}{l}0 \\
(.)\end{array}$ & $\begin{array}{l}0 \\
(.)\end{array}$ & $\begin{array}{l}0 \\
(.)\end{array}$ & $\begin{array}{c}0 \\
(.)\end{array}$ & $\begin{array}{c}72.9 * \\
(43.29)\end{array}$ & $\begin{array}{l}-69.3 \\
(48.60)\end{array}$ & $\begin{array}{c}-90.2 * * \\
(37.06)\end{array}$ \\
\hline Chair & $\begin{array}{l}-2.45 \\
(3.72)\end{array}$ & $\begin{array}{c}3.75 \\
(5.59)\end{array}$ & $\begin{array}{l}12.8^{*} \\
(7.49)\end{array}$ & $\begin{array}{l}19.0 * \\
(10.45)\end{array}$ & $\begin{array}{l}17.0 * \\
(9.86)\end{array}$ & $\begin{array}{l}33.5 * * \\
(11.19)\end{array}$ & $\begin{array}{l}21.0 * \\
(10.00)\end{array}$ & $\begin{array}{l}25.9 * * \\
(11.04)\end{array}$ & $\begin{array}{l}11.2 \\
(11.66)\end{array}$ & $\begin{array}{l}16.9 * \\
(9.04)\end{array}$ \\
\hline Ranking Member & $\begin{array}{l}-3.01 \\
(3.72)\end{array}$ & $\begin{array}{l}-8.61 \\
(5.35)\end{array}$ & $\begin{array}{l}0.75 \\
(7.21)\end{array}$ & $\begin{array}{l}-8.48 \\
(10.29)\end{array}$ & $\begin{array}{l}-1.58 \\
(9.63)\end{array}$ & $\begin{array}{l}-11.1 \\
(11.31)\end{array}$ & $\begin{array}{l}-12.7 \\
(10.07)\end{array}$ & $\begin{array}{l}-0.20 \\
(10.47)\end{array}$ & $\begin{array}{l}-7.11 \\
(11.76)\end{array}$ & $\begin{array}{l}-7.25 \\
(8.59)\end{array}$ \\
\hline
\end{tabular}




\begin{tabular}{|c|c|c|c|c|c|c|c|c|c|c|}
\hline Seniority & $\begin{array}{l}0.13 \\
(0.22)\end{array}$ & $\begin{array}{l}0.14 \\
(0.33)\end{array}$ & $\begin{array}{l}0.75 \\
(0.48)\end{array}$ & $\begin{array}{l}1.36^{*} \\
(0.66)\end{array}$ & $\begin{array}{l}1.07 * \\
(0.63)\end{array}$ & $\begin{array}{l}1.29^{*} \\
(0.69)\end{array}$ & $\begin{array}{l}0.96 \\
(0.62)\end{array}$ & $\begin{array}{l}2.04 * * \\
(0.68)\end{array}$ & $\begin{array}{l}2.81^{* * * *} \\
(0.69)\end{array}$ & $\begin{array}{l}2.24 * * * \\
(0.52)\end{array}$ \\
\hline $\begin{array}{l}\text { Prestigious } \\
\text { Committee }\end{array}$ & $\begin{array}{l}0.25 \\
(2.57)\end{array}$ & $\begin{array}{l}4.79 \\
(3.92)\end{array}$ & $\begin{array}{l}3.70 \\
(4.97)\end{array}$ & $\begin{array}{l}8.67 \\
(7.00)\end{array}$ & $\begin{array}{l}-1.95 \\
(6.65)\end{array}$ & $\begin{array}{l}6.71 \\
(7.63)\end{array}$ & $\begin{array}{l}21.4^{* * * *} \\
(6.72)\end{array}$ & $\begin{array}{l}-5.50 \\
(7.38)\end{array}$ & $\begin{array}{l}11.2 \\
(7.50)\end{array}$ & $\begin{array}{l}1.75 \\
(5.68)\end{array}$ \\
\hline $\begin{array}{l}\text { Distributive } \\
\text { Committee }\end{array}$ & $\begin{array}{l}-0.92 \\
(1.94)\end{array}$ & $\begin{array}{l}1.78 \\
(2.94)\end{array}$ & $\begin{array}{l}2.78 \\
(3.87)\end{array}$ & $\begin{array}{l}-0.29 \\
(5.46)\end{array}$ & $\begin{array}{l}-7.19 \\
(5.10)\end{array}$ & $\begin{array}{l}-6.74 \\
(6.05)\end{array}$ & $\begin{array}{l}1.80 \\
(5.43)\end{array}$ & $\begin{array}{l}-1.83 \\
(5.67)\end{array}$ & $\begin{array}{c}-2.11 \\
(6.19)\end{array}$ & $\begin{array}{l}-8.56^{*} \\
(4.74)\end{array}$ \\
\hline $\begin{array}{l}\text { Policy } \\
\text { Committee }\end{array}$ & $\begin{array}{l}-0.76 \\
(1.91)\end{array}$ & $\begin{array}{l}4.96^{*} \\
(2.79)\end{array}$ & $\begin{array}{l}4.51 \\
(3.65)\end{array}$ & $\begin{array}{l}9.34 * \\
(5.04)\end{array}$ & $\begin{array}{l}-0.93 \\
(4.63)\end{array}$ & $\begin{array}{l}-0.52 \\
(5.35)\end{array}$ & $\begin{array}{l}2.29 \\
(4.81)\end{array}$ & $\begin{array}{l}-3.59 \\
(5.20)\end{array}$ & $\begin{array}{l}-2.23 \\
(5.40)\end{array}$ & $\begin{array}{l}-0.16 \\
(4.13)\end{array}$ \\
\hline Constant & $\begin{array}{c}42.3^{* * *} \\
(4.06)\end{array}$ & $\begin{array}{l}43.2 * * * \\
(5.81)\end{array}$ & $\begin{array}{l}47.1^{* * *} \\
(7.78)\end{array}$ & $\begin{array}{l}68.2 * * * \\
(10.65)\end{array}$ & $\begin{array}{l}93.5^{* * *} \\
(10.29)\end{array}$ & $\begin{array}{l}59.3 * * * \\
(13.69)\end{array}$ & $\begin{array}{l}60.9 * * * \\
(12.54)\end{array}$ & $\begin{array}{l}66.0 * * * \\
(13.49)\end{array}$ & $\begin{array}{l}34.4^{*} \\
(14.84)\end{array}$ & $\begin{array}{l}36.4 * * \\
(11.90)\end{array}$ \\
\hline $\begin{array}{l}\mathrm{N} \\
\mathrm{R} \text {-squared } \\
\text { F-Statistic }\end{array}$ & $\begin{array}{l}438 \\
.0929 \\
3.63 * * *\end{array}$ & $\begin{array}{l}437 \\
.1374 \\
5.63 * * *\end{array}$ & $\begin{array}{l}439 \\
.1506 \\
6.29 * * *\end{array}$ & $\begin{array}{l}435 \\
.1024 \\
4.01 * * *\end{array}$ & $\begin{array}{l}437 \\
.2143 \\
9.64 * * *\end{array}$ & $\begin{array}{l}437 \\
.1418 \\
5.84 * * *\end{array}$ & $\begin{array}{l}439 \\
.1826 \\
7.93^{* * *}\end{array}$ & $\begin{array}{l}437 \\
.1750 \\
6.90 * * *\end{array}$ & $\begin{array}{l}437 \\
.1668 \\
6.52 * * *\end{array}$ & $\begin{array}{l}434 \\
.1602 \\
6.16^{* * *}\end{array}$ \\
\hline
\end{tabular}

NOTES: Each column presents the full OLS model per congressional session. Standard errors are in parentheses.

$* \mathrm{p}<0.05,{ }^{* *} \mathrm{p}<0.01, * * * \mathrm{p}<0.001$ 
Table A2.9: Full OLS Models, Including Dummy Interaction Terms, of Legislative Entrepreneurship in the U.S. House, 94th-103rd Congresses

\begin{tabular}{|c|c|}
\hline Female Democrat & $\begin{array}{l}7.57^{* *} \\
(3.14)\end{array}$ \\
\hline Female Republican & $\begin{array}{l}13.4^{* *} \\
(4.38)\end{array}$ \\
\hline Male Republican & $\begin{array}{l}-1.46 \\
(2.46)\end{array}$ \\
\hline $\begin{array}{l}\text { Distance From } \\
\text { Chamber Median }\end{array}$ & $\begin{array}{l}43.4 * * * \\
(5.76)\end{array}$ \\
\hline $\begin{array}{l}\text { Distance From } \\
\text { Party Median }\end{array}$ & $\begin{array}{l}-50.5^{* * *} \\
(5.99)\end{array}$ \\
\hline African American & $\begin{array}{l}-1.09 \\
(2.90)\end{array}$ \\
\hline Latino & $\begin{array}{l}-6.20 \\
(3.94)\end{array}$ \\
\hline Speaker & $\begin{array}{l}-29.9 \\
(21.70)\end{array}$ \\
\hline Chair & $\begin{array}{l}16.0 * * * \\
(2.94)\end{array}$ \\
\hline $\begin{array}{l}\text { Ranking } \\
\text { Member }\end{array}$ & $\begin{array}{l}-4.83^{*} \\
(2.90)\end{array}$ \\
\hline Seniority & $\begin{array}{l}1.26^{* * *} \\
(0.18)\end{array}$ \\
\hline $\begin{array}{l}\text { Prestigious } \\
\text { Committee }\end{array}$ & $\begin{array}{l}5.33^{* *} \\
(1.96)\end{array}$ \\
\hline $\begin{array}{l}\text { Distributive } \\
\text { Committee }\end{array}$ & $\begin{array}{l}-2.37 \\
(1.54)\end{array}$ \\
\hline $\begin{array}{l}\text { Policy } \\
\text { Committee }\end{array}$ & $\begin{array}{l}1.59 \\
(1.41)\end{array}$ \\
\hline $94^{\text {th }}$ Congress & $\begin{array}{l}-18.4 * * * \\
(2.55)\end{array}$ \\
\hline $95^{\text {th }}$ Congress & $\begin{array}{l}-21.0 * * * \\
(2.56)\end{array}$ \\
\hline
\end{tabular}




\begin{tabular}{ll}
$96^{\text {th }}$ Congress & $-6.52^{* *}$ \\
& $(2.55)$ \\
& $5.37 *$ \\
$97^{\text {th }}$ Congress & $(2.55)$ \\
& $8.53^{* * *}$ \\
& $(2.55)$ \\
$98^{\text {th }}$ Congress & 3.34 \\
& $(2.54)$ \\
$99^{\text {th }}$ Congress & $7.35^{* *}$ \\
& $(2.54)$ \\
$100^{\text {th }}$ Congress & $11.1^{* * *}$ \\
& $(2.54)$ \\
$101^{\text {st }}$ Congress & $14.7^{* * *}$ \\
& $(2.54)$ \\
$102^{\text {nd }}$ Congress & $58.4^{* * *}$ \\
& $(2.89)$ \\
Constant & 4370 \\
\hline R-squared & .1857 \\
\hline F-Statistic & $43.09 * * *$ \\
\hline NOTES: Standard errors are in & parentheses. $* 0.05, * * \mathrm{p}<0.01, * * * \mathrm{p}<0.001$ \\
\hline
\end{tabular}




\section{CHAPTER 3}

\section{Data Sources:}

- Congressional Hearings Data, Policy Agendas Project, Accessed 3/22/2016: http://www.policyagendas.org/page/datasets-codebooks\#congressional_hearings

- Information on other variables concerning Congress:

○ http://history.house.gov/Institution/Party-Divisions/Party-Divisions/

○ http://history.house.gov/Institution/Presidents-Coinciding/PresidentsCoinciding/

○ http://history.house.gov/Institution/Session-Dates/80-89/

- Public Mood, Extended from Christopher Ellis and James A. Stimson, Ideology in America, New York, Cambridge University Press, 2012.: http://stimson.web.unc.edu/data/ 


\section{Table A3.1: Data Sources, Definitions, and Descriptive Statistics}

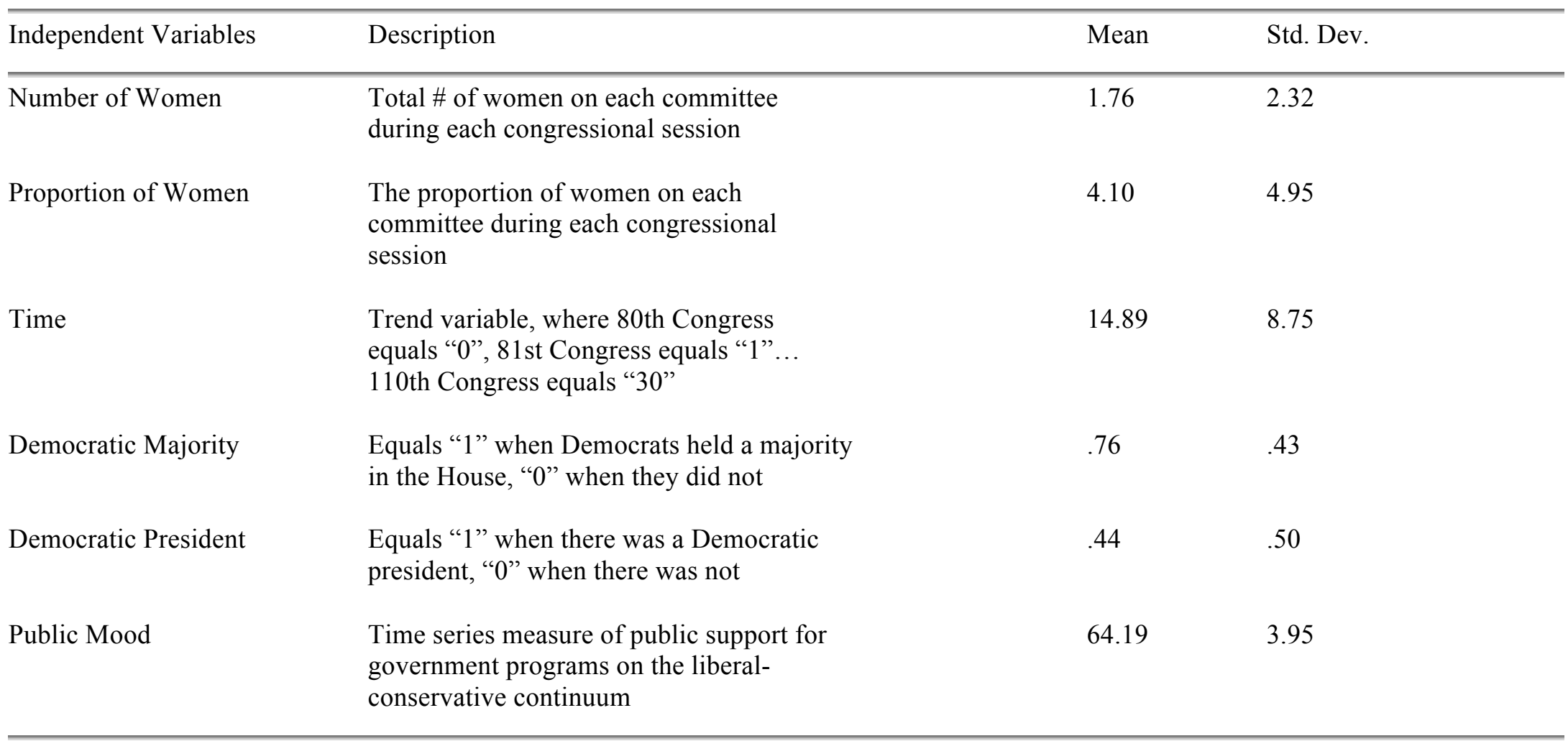


Table A3.2: Full OLS Models Comparing Proportion of Women \& Number of Women

\begin{tabular}{|c|c|c|c|c|}
\hline & (1) & (2) & (3) & (4) \\
\hline $\begin{array}{l}\text { Proportion Women } \\
\text { on Committees }\end{array}$ & $\begin{array}{l}1.10^{* * *} \\
(0.26)\end{array}$ & & $\begin{array}{l}-0.050 \\
(0.38)\end{array}$ & \\
\hline $\begin{array}{l}\text { Number of } \\
\text { Women }\end{array}$ & & $\begin{array}{l}4.87 * * * \\
(0.57)\end{array}$ & & $\begin{array}{l}-0.88 \\
(0.87)\end{array}$ \\
\hline Time & $\begin{array}{l}1.36 * * * \\
(0.17)\end{array}$ & $\begin{array}{l}0.92 * * * \\
(0.16)\end{array}$ & $\begin{array}{l}-1.15 * * * \\
(0.24)\end{array}$ & $\begin{array}{l}-1.01 * * * \\
(0.25)\end{array}$ \\
\hline $\begin{array}{l}\text { Democrat } \\
\text { Majority }\end{array}$ & $\begin{array}{l}-5.43^{*} \\
(2.68)\end{array}$ & $\begin{array}{l}-2.31 \\
(2.58)\end{array}$ & $\begin{array}{l}-0.87 \\
(3.91)\end{array}$ & $\begin{array}{l}-1.67 \\
(3.95)\end{array}$ \\
\hline $\begin{array}{l}\text { Democrat } \\
\text { Presidency }\end{array}$ & $\begin{array}{l}0.95 \\
(2.09)\end{array}$ & $\begin{array}{l}1.83 \\
(1.99)\end{array}$ & $\begin{array}{l}-4.86 \\
(3.05)\end{array}$ & $\begin{array}{l}-5.18^{*} \\
(3.04)\end{array}$ \\
\hline Agriculture & $\begin{array}{l}-14.4^{* *} \\
(5.16)\end{array}$ & $\begin{array}{l}-15.0 * * \\
(4.90)\end{array}$ & $\begin{array}{l}7.54 \\
(7.51)\end{array}$ & $\begin{array}{l}7.61 \\
(7.51)\end{array}$ \\
\hline Appropriations & $\begin{array}{l}73.3 * * * \\
(5.17)\end{array}$ & $\begin{array}{l}67.9^{* * * *} \\
(4.97)\end{array}$ & $\begin{array}{l}-3.12 \\
(7.54)\end{array}$ & $\begin{array}{l}-1.90 \\
(7.62)\end{array}$ \\
\hline Armed Services & $\begin{array}{l}-4.28 \\
(5.22)\end{array}$ & $\begin{array}{l}-11.0^{*} \\
(5.04)\end{array}$ & $\begin{array}{l}19.8^{* *} \\
(7.61)\end{array}$ & $\begin{array}{l}21.5 * * \\
(7.72)\end{array}$ \\
\hline Banking & $\begin{array}{l}-9.58^{*} \\
(5.27)\end{array}$ & $\begin{array}{l}-17.9 * * * \\
(5.12)\end{array}$ & $\begin{array}{l}4.79 \\
(7.68)\end{array}$ & $\begin{array}{l}6.92 \\
(7.85)\end{array}$ \\
\hline Budget & $\begin{array}{l}-21.1 * * * \\
(5.98)\end{array}$ & $\begin{array}{l}-22.2 * * * \\
(5.65)\end{array}$ & $\begin{array}{l}-18.3^{*} \\
(8.72)\end{array}$ & $\begin{array}{l}-17.6^{*} \\
(8.66)\end{array}$ \\
\hline $\mathrm{DC}$ & $\begin{array}{l}-19.1 * * * \\
(5.63)\end{array}$ & $\begin{array}{l}-18.2^{* * * *} \\
(5.30)\end{array}$ & $\begin{array}{l}-8.75 \\
(8.20)\end{array}$ & $\begin{array}{l}-8.45 \\
(8.12)\end{array}$ \\
\hline Education & $\begin{array}{l}-9.46^{*} \\
(5.22)\end{array}$ & $\begin{array}{l}-13.5^{* *} \\
(4.98)\end{array}$ & $\begin{array}{l}17.2^{*} \\
(7.61)\end{array}$ & $\begin{array}{l}18.4 * * \\
(7.63)\end{array}$ \\
\hline $\begin{array}{l}\text { Government } \\
\text { Operations }\end{array}$ & $\begin{array}{l}19.2 * * * \\
(5.20)\end{array}$ & $\begin{array}{l}15.8^{* * *} \\
(4.95)\end{array}$ & $\begin{array}{l}-3.32 \\
(7.58)\end{array}$ & $\begin{array}{l}-2.33 \\
(7.59)\end{array}$ \\
\hline Commerce & $\begin{array}{l}-0.55 \\
(5.18)\end{array}$ & $\begin{array}{l}-4.73 \\
(4.95)\end{array}$ & $\begin{array}{l}34.5 * * * \\
(7.55)\end{array}$ & $\begin{array}{l}35.6 * * * \\
(7.59)\end{array}$ \\
\hline Foreign Affairs & $\begin{array}{l}3.58 \\
(5.18)\end{array}$ & $\begin{array}{l}0.32 \\
(4.94)\end{array}$ & $\begin{array}{l}5.24 \\
(7.55)\end{array}$ & $\begin{array}{l}6.14 \\
(7.57)\end{array}$ \\
\hline
\end{tabular}




\begin{tabular}{|c|c|c|c|c|}
\hline $\begin{array}{l}\text { House } \\
\text { Administration }\end{array}$ & $\begin{array}{l}-26.2^{* * * *} \\
(5.32)\end{array}$ & $\begin{array}{l}-22.2^{* * *} \\
(4.99)\end{array}$ & $\begin{array}{l}-20.2^{* *} \\
(7.76)\end{array}$ & $\begin{array}{l}-20.4^{* *} \\
(7.65)\end{array}$ \\
\hline Interior & $\begin{array}{l}-10.7^{*} \\
(5.17)\end{array}$ & $\begin{array}{l}-13.1 * * \\
(4.92)\end{array}$ & $\begin{array}{l}53.9 * * * \\
(7.53)\end{array}$ & $\begin{array}{l}54.5^{* * *} \\
(7.54)\end{array}$ \\
\hline Judiciary & $\begin{array}{l}3.60 \\
(5.18)\end{array}$ & $\begin{array}{l}2.37 \\
(4.91)\end{array}$ & $\begin{array}{l}53.4 * * * \\
(7.55)\end{array}$ & $\begin{array}{l}53.9 * * * \\
(7.53)\end{array}$ \\
\hline $\begin{array}{l}\text { Merchant } \\
\text { Marine }\end{array}$ & $\begin{array}{l}-13.1^{* *} \\
(5.61)\end{array}$ & $\begin{array}{l}-16.0^{* *} \\
(5.33)\end{array}$ & $\begin{array}{l}8.01 \\
(8.18)\end{array}$ & $\begin{array}{l}8.92 \\
(8.17)\end{array}$ \\
\hline Post Office & $\begin{array}{l}-12.9^{*} \\
(5.70)\end{array}$ & $\begin{array}{l}-14.1 * * \\
(5.34)\end{array}$ & $\begin{array}{l}6.37 \\
(8.30)\end{array}$ & $\begin{array}{l}7.28 \\
(8.19)\end{array}$ \\
\hline Public Works & $\begin{array}{l}-7.14 \\
(5.17)\end{array}$ & $\begin{array}{l}-13.1^{* *} \\
(4.98)\end{array}$ & $\begin{array}{l}-2.50 \\
(7.54)\end{array}$ & $\begin{array}{l}-1.16 \\
(7.64)\end{array}$ \\
\hline Science & $\begin{array}{l}-5.20 \\
(5.41)\end{array}$ & $\begin{array}{l}-9.51 * \\
(5.16)\end{array}$ & $\begin{array}{l}-2.72 \\
(7.88)\end{array}$ & $\begin{array}{l}-1.55 \\
(7.92)\end{array}$ \\
\hline $\begin{array}{l}\text { Small } \\
\text { Business }\end{array}$ & $\begin{array}{c}-19.5 * * * \\
(6.11)\end{array}$ & $\begin{array}{l}-21.7 * * * \\
(5.78)\end{array}$ & $\begin{array}{l}-6.95 \\
(8.90)\end{array}$ & $\begin{array}{l}-6.00 \\
(8.86)\end{array}$ \\
\hline $\begin{array}{l}\text { Veterans } \\
\text { Affairs }\end{array}$ & $\begin{array}{l}-19.0^{* * * *} \\
(5.20)\end{array}$ & $\begin{array}{l}-19.5^{* * *} \\
(4.91)\end{array}$ & $\begin{array}{l}-10.4 \\
(7.57)\end{array}$ & $\begin{array}{l}-9.94 \\
(7.53)\end{array}$ \\
\hline $\begin{array}{l}\text { Public } \\
\text { Mood }\end{array}$ & $\begin{array}{r}-0.097 \\
(0.23)\end{array}$ & $\begin{array}{l}-0.13 \\
(0.22)\end{array}$ & $\begin{array}{l}-0.80 * * \\
(0.34)\end{array}$ & $\begin{array}{l}-0.80 * * \\
(0.34)\end{array}$ \\
\hline Constant & $\begin{array}{l}11.6 \\
(16.92)\end{array}$ & $\begin{array}{l}16.4 \\
(16.08)\end{array}$ & $\begin{array}{l}97.1 * * * \\
(24.66)\end{array}$ & $\begin{array}{l}96.3 * * * \\
(24.65)\end{array}$ \\
\hline $\begin{array}{l}\mathrm{N} \\
\mathrm{R} \text {-squared } \\
\text { F-statistic }\end{array}$ & $\begin{array}{l}530 \\
.6599 \\
40.82^{* * *}\end{array}$ & $\begin{array}{l}530 \\
.6929 \\
47.49 * * *\end{array}$ & $\begin{array}{l}530 \\
.3923 \\
13.58 * * *\end{array}$ & $\begin{array}{l}530 \\
.3935 \\
13.65^{* * *}\end{array}$ \\
\hline
\end{tabular}

NOTES: Standard errors are in parentheses. ${ }^{*} \mathrm{p}<0.05, * * \mathrm{p}<0.01, * * * \mathrm{p}<0.001$. Models $1 \& 2$ use the number of oversight hearings as the dependent variable; Models $3 \& 4$ use the number of legislative hearings as the dependent variable. 


\section{CHAPTER 4}

\section{Data sources:}

- E. Scott Adler and John Wilkerson, Congressional Bills Project: (93rd-114th congresses), NSF 00880066 and 00880061 . The views expressed are those of the authors and not the National Science Foundation. Accessed 8/1/16.

- U.S. Census, American Communities Survey, via American FactFinder (109-113 congresses). Accessed several times, final data download 10/8/16. 


\section{Table A4.1: Data Sources, Definitions, and Descriptive Statistics}

\begin{tabular}{|c|c|c|c|}
\hline Independent Variables & Description & Mean & Std. Dev. \\
\hline Congresswomen & Equals " 1 " for woman, " 0 " for man & .17 & .38 \\
\hline Party Identification & Equals " 1 " for Republicans, " 0 " for Democrats & .50 & .50 \\
\hline $\begin{array}{l}\text { 1st Dimension } \\
\text { DW-NOMINATE }\end{array}$ & Ideology Score, Pool \& Rosenthal (2007) & .14 & .53 \\
\hline Majority Party & Equals " 1 " if member of majority party, " 0 " if not & .56 & .50 \\
\hline United Government & Equals " 1 " if House and President of same party, " 0 " if not & .40 & .49 \\
\hline $\begin{array}{l}\text { Log Number } \\
\text { Congresswomen }\end{array}$ & Log of number of congresswomen within a session & 4.30 & .05 \\
\hline $\begin{array}{l}\text { Log Median Household } \\
\text { Income }\end{array}$ & Log of median household income within member's district & 10.84 & .25 \\
\hline Log Divorced Women & Log of number of divorced women within member's district & 10.44 & .20 \\
\hline Log Wealthy Women & Log of number of wealthy women within member's district & 8.43 & .81 \\
\hline $\begin{array}{l}\text { Log Girls Under Five } \\
\text { in Poverty }\end{array}$ & Log of number of girls under 5 within member's district & 8.44 & .56 \\
\hline Log Lesbian Households & Log of number of lesbian households within member's district & 6.40 & .57 \\
\hline Log Women Veterans & Log of number of women veterans within member's district & 8.03 & .60 \\
\hline
\end{tabular}




\section{Table A4.2: Coding Women's Issue Bills According to Policy Agendas Project Subtopic Codes \& Swers' (2002) Definition}

The following information was taken from the websites of these women's organizations, which Swers specifically refers to in the Appendix of her 2002 book, The Difference Women Make:

1. Liberal groups: the American Association of University Women and the National Organization for Women.

- AAUW: http://www.aauw.org/what-we-do/public-policy/aauw-issues/

Civil rights: "AAUW advocates for equality, individual rights, and social justice for a diverse society."(Affirmative action, Federal judicial nominations, Hate crimes prevention, Lesbian, Gay, bisexual, and transgender issues, Reproductive rights)

Education: "AAUW supports a strong system of public education that promotes gender fairness, equity, and diversity." (Career and technical education, Charter schools, Disabilities, Education and training in welfare/TANF, Higher education, No Child Left Behind Act, School vouchers, Single-sex education, STEM education)

Economic Security: "AAUW advocates for all women to achieve economic self-sufficiency." (Work-life Balance, Pay equity, Retirement security, Health care, Social Security privatization)

Title IX: "AAUW supports vigorous enforcement of Title IX and all other civil rights laws pertaining to education.” (Title IX, Equity in school athletics, Sexual harassment, Single-sex education)

- NOW: http://www.now.org/issues/

Top Priority Issues: Abortion rights/reproductive issues, violence against women, constitutional equality, Promoting diversity and ending racism, lesbian rights, and economic justice.

Other issues: Affirmative Action, Disability Rights, Family/Family Law, Fighting the Right, Global Feminism, Health, Immigration, Judicial Nominations, Legislation, Marriage Equality, Media Activism, Mothers/Caregivers Economic Rights, Working for Peace, Social Security, Supreme Court, Title IX/Education, Welfare, Women-Friendly Workplace, Women in the Military, Young Feminist Programs

2. Conservative groups: Concerned Women for America and Eagle Forum.

- CWFA: http://www.cwfa.org/coreissues.asp

Core issues: Sanctity of life, religious liberty, family (traditional marriage), pornography, education (parents' rights), and national sovereignty (CWA believes that neither the United Nations nor any other international organization should have authority over the United States in any area. We also believe the United States has the right and duty to protect and secure our national borders. We believe in budget restraint which embodies responsible spending, small government and a budget in which the U.S. government spends within its means and ceases to steal from future generations.)

- Eagle Forum: http://www.eagleforum.org/topics/

CONSTITUTION: 2nd Amendment, Con Con/Article V, DC/HI/PR Statehood, Equal Rights Amendment, Electoral College, Executive Orders, Keep an Elected Congress

COURTS/JUDGES: Amicus Briefs, Court Watch, Judges, Marriage, Pledge of Allegiance, Property

Rights, Schlafly Book - Supremacists, Ten Commandments

EDUCATION: Common Core 


\section{ENGLISH LANGUAGE}

FAMILY / FATHERS / FEMINISM: Domestic Violence/VAWA, Equal Rights Amendment, Fathers, Feminism, Feminist Fantasies, The Flipside of Feminism, Marriage, Parents' Rights, Title IX, Women's Treaty (CEDAW)

Globalism vs Sovereignty: Global Governance, Global Warming, Law of the Sea, North American Union, Panama Canal, Rights of the Child, United Nations, Women's Treaty (CEDAW)

HEALTH/LIFE ISSUES: Health Care Reform, Eagle Forum Opposes Personhood Amendment, Vaccines IMMIGRATION/BORDERS: Amnesty/Guest-Worker, Border Security \& Immigration, Mexican Trucks, North American Union, Terrorism

JOBS/ECONOMY/TRADE: Amnesty/Guest-Worker, FTAA \& CAFTA, Jobs/Economy, North American Union, Patent Rights

PRIVACY/DATABASES: Privacy/Databases, Medical Privacy, National ID, Nosy Surveys \& Data Collection, Social Security \#s

3. The Congressional Caucus for Women's Issues (later reconfigured as Women's Policy, Inc.) is a bipartisan, but liberal-leaning congressional caucus.

http://www.womenspolicy.org/site/PageServer

Mission Statement: Women's Policy, Inc. (WPI) champions the interests of women throughout the country on the most significant social, economic, and health issues across the public policy spectrum. WPI is a nonprofit, nonpartisan organization whose sole focus is to help ensure that the most informed decisions on key women's issues are made by policymakers at the federal, state, and local levels. Audiences include elected officials, regulators, women's groups, labor groups, academia, the business community, the media, and the general public. WPI achieves and shares its rare quality of insight into relevant issues by researching and producing the best available information in the form of compelling and unbiased legislative analyses, issue summaries, impact assessments, and educational briefings. This ensures that policy decisions affecting women and their families have the benefit of input from the most objective sources possible.

The Caucus' Accomplishments:

The Pregnancy Discrimination Act

The Child Support Enforcement Act

The Retirement Equity Act

The Civil Rights Restoration Act

The Women's Business Ownership Act

The Breast and Cervical Cancer Mortality Prevention Act

The Mammography Quality Standards Act

The Family and Medical Leave Act

The Violence Against Women Act

The Commission on the Advancement of Women and Minorities in Science, Engineering, and

Technology Development Act

Reauthorization of the Mammography Quality Standards Act

Contraceptive Coverage for Federal Employees

Table A4.3: Reliability of Women's Issue Subtopic Coding

$\%$ Expected Agreement

58.88

$\%$ Agreement

Kappa

83.19

$.59 *$

$*=\mathrm{p}<.001$ 
Table A4.4: The Effects of Gender \& Party Identification Interaction on Women's Issue Bill Introductions, 109-113th Congress

\begin{tabular}{|c|c|c|c|}
\hline & (1) & (2) & (3) \\
\hline Congresswomen & $\begin{array}{l}0.21 * * * \\
(0.05)\end{array}$ & $\begin{array}{l}0.22 * * * \\
(0.06)\end{array}$ & $\begin{array}{l}0.22 * * * \\
(0.07)\end{array}$ \\
\hline Party Identification & $\begin{array}{l}-0.32 * * * \\
(0.04)\end{array}$ & $\begin{array}{l}-0.32 * * * \\
(0.04)\end{array}$ & $\begin{array}{l}-0.32 * * * \\
(0.04)\end{array}$ \\
\hline Majority Party & $\begin{array}{l}0.11 * * * \\
(0.04)\end{array}$ & $\begin{array}{l}0.11^{* * *} \\
(0.04)\end{array}$ & $\begin{array}{l}0.11 * * \\
(0.04)\end{array}$ \\
\hline $\begin{array}{l}\text { Congresswomen } \mathbf{X} \\
\text { Party Identification }\end{array}$ & & $\begin{array}{r}-0.023 \\
(0.10)\end{array}$ & \\
\hline $\begin{array}{l}\text { Congresswomen } \mathbf{X} \\
\text { Majority Party }\end{array}$ & & & $\begin{array}{l}-0.0037 \\
(0.09)\end{array}$ \\
\hline United Government & $\begin{array}{l}0.070 \\
(0.04)\end{array}$ & $\begin{array}{l}0.070 \\
(0.04)\end{array}$ & $\begin{array}{l}0.071 \\
(0.04)\end{array}$ \\
\hline $\begin{array}{l}\text { Log Number } \\
\text { Congresswomen }\end{array}$ & $\begin{array}{l}0.21 \\
(0.41)\end{array}$ & $\begin{array}{l}0.20 \\
(0.41)\end{array}$ & $\begin{array}{l}0.21 \\
(0.41)\end{array}$ \\
\hline $\begin{array}{l}\text { Log Black } \\
\text { Population }\end{array}$ & $\begin{array}{l}0.027^{*} \\
(0.02)\end{array}$ & $\begin{array}{l}0.027^{*} \\
(0.02)\end{array}$ & $\begin{array}{l}0.027^{*} \\
(0.02)\end{array}$ \\
\hline $\begin{array}{l}\text { Log Median } \\
\text { Household Income }\end{array}$ & $\begin{array}{l}0.58 * * * \\
(0.07)\end{array}$ & $\begin{array}{l}0.58 * * * \\
(0.07)\end{array}$ & $\begin{array}{l}0.58 * * * \\
(0.07)\end{array}$ \\
\hline Constant & $\begin{array}{l}-5.77 * * \\
(1.94)\end{array}$ & $\begin{array}{l}-5.75 * * \\
(1.94)\end{array}$ & $\begin{array}{l}-5.77 * * \\
(1.94)\end{array}$ \\
\hline $\begin{array}{l}\text { Log Alpha } \\
\text { Constant }\end{array}$ & $\begin{array}{l}-0.63 * * * \\
(0.04)\end{array}$ & $\begin{array}{l}-0.63 * * * \\
(0.04)\end{array}$ & $\begin{array}{l}-0.63 * * * \\
(0.04)\end{array}$ \\
\hline $\begin{array}{l}\mathrm{N} \\
\text { Pseudo R-squared }\end{array}$ & $\begin{array}{l}2362 \\
0.01\end{array}$ & $\begin{array}{l}2362 \\
0.01\end{array}$ & $\begin{array}{l}2362 \\
0.01\end{array}$ \\
\hline
\end{tabular}

Note: Variance exceeds the mean indicating negative binomial regression is appropriate. Standard errors in parentheses. ${ }^{*} \mathrm{p}<0.05, * * \mathrm{p}<0.01, * * * \mathrm{p}<0.001$.

Table A4.5: Further Effects of Gender \& Party Identification on Women's Issue Bill Introductions with Gender and Party Dummy Interactions, 109-113th Congress

Female Democrats $\quad 0.54 * * *$




\begin{tabular}{ll} 
Female Republicans & $\begin{array}{l}0.20^{* *} \\
(0.08)\end{array}$ \\
Male Democrats & $\begin{array}{l}0.32^{* * *} \\
(0.04)\end{array}$ \\
& $0.11^{* * *}$ \\
Majority Party & $(0.04)$ \\
& 0.070 \\
United Government & $(0.04)$ \\
& 0.20 \\
Log Number & $(0.41)$ \\
Congresswomen & $0.027^{*}$ \\
Log Black & $(0.02)$ \\
Population & $0.58^{* * *}$ \\
Log Median & $(0.07)$ \\
Household Income & $-6.07 * * *$ \\
Constant & $(1.94)$ \\
\hline Log Alpha & $-0.63 * * *$ \\
Constant & $(0.04)$ \\
\hline Pseudo R-squared & 2362 \\
& 0.01 \\
\hline
\end{tabular}

Note: Variance exceeds the mean indicating negative binomial regression is appropriate. Standard errors in parentheses. ${ }^{*} \mathrm{p}<0.05,{ }^{* *} \mathrm{p}<0.01,{ }^{* * *} \mathrm{p}<0.001$.

Table A4.6: Women's Issue Bill Introductions with and without Congressional Session Fixed Effects, 109-113th Congress

\begin{tabular}{lllll}
\hline & $\mathbf{( 1 )}$ & $\mathbf{( 2 )}$ & $\mathbf{( 3 )}$ & $\mathbf{( 4 )}$ \\
\hline Congresswomen & $\begin{array}{l}0.21^{* * *} \\
(0.05)\end{array}$ & $\begin{array}{l}0.21^{* * *} \\
(0.05)\end{array}$ & $\begin{array}{l}0.20^{* * *} \\
(0.05)\end{array}$ & $\begin{array}{l}0.20^{* * *} \\
(0.05)\end{array}$ \\
& & & \\
Party Identification & $-0.32^{* * *}$ & $-0.31^{* * *}$ & & \\
& $(0.04)$ & $(0.04)$ & & $-0.32 * * *$ \\
1st Dimension & & & $-0.33 * * *$ & $(0.03)$ \\
DW-NOMINATE & & & $(0.03)$ & $0.12 * * *$ \\
Majority Party & $0.11^{* * *}$ & $0.11^{* *}$ & $0.12 * * *$ & $(0.04)$
\end{tabular}




\begin{tabular}{|c|c|c|c|c|}
\hline United Government & $\begin{array}{l}0.070^{*} \\
(0.04)\end{array}$ & $\begin{array}{l}0.15^{* *} \\
(0.06)\end{array}$ & $\begin{array}{l}0.067 \\
(0.04)\end{array}$ & $\begin{array}{l}0.14^{* *} \\
(0.06)\end{array}$ \\
\hline $\begin{array}{l}\text { Log Number } \\
\text { Congresswomen }\end{array}$ & $\begin{array}{c}0.21 \\
(0.41)\end{array}$ & $\begin{array}{l}1.00 \\
(0.62)\end{array}$ & $\begin{array}{l}0.24 \\
(0.41)\end{array}$ & $\begin{array}{l}0.95 \\
(0.62)\end{array}$ \\
\hline $\begin{array}{l}\text { Log Black } \\
\text { Population }\end{array}$ & $\begin{array}{l}0.027^{*} \\
(0.02)\end{array}$ & $\begin{array}{l}0.027^{*} \\
(0.02)\end{array}$ & $\begin{array}{l}0.024 \\
(0.02)\end{array}$ & $\begin{array}{l}0.023 \\
(0.02)\end{array}$ \\
\hline $\begin{array}{l}\text { Log Median } \\
\text { Household Income }\end{array}$ & $\begin{array}{l}0.58 * * * \\
(0.07)\end{array}$ & $\begin{array}{l}0.57 * * * \\
(0.07)\end{array}$ & $\begin{array}{l}0.58^{* * *} \\
(0.07)\end{array}$ & $\begin{array}{l}0.57 * * * \\
(0.07)\end{array}$ \\
\hline $109^{\text {th }}$ Congress & & $\begin{array}{l}0.034 \\
(0.07)\end{array}$ & & $\begin{array}{l}0.020 \\
(0.07)\end{array}$ \\
\hline $110^{\text {th }}$ Congress & & $\begin{array}{l}0.13^{*} \\
(0.06)\end{array}$ & & $\begin{array}{l}0.13^{*} \\
(0.06)\end{array}$ \\
\hline $111^{\text {th }}$ Congress & & $\begin{array}{l}0 \\
(.)\end{array}$ & & $\begin{array}{l}0 \\
(.)\end{array}$ \\
\hline $112^{\text {th }}$ Congress & & $\begin{array}{l}0 \\
(.)\end{array}$ & & $\begin{array}{l}0 \\
(.)\end{array}$ \\
\hline Constant & $\begin{array}{l}-5.09 * * * \\
(0.91)\end{array}$ & $\begin{array}{l}-5.78 * * * \\
(1.01)\end{array}$ & $\begin{array}{l}-5.18 * * * \\
(0.91)\end{array}$ & $\begin{array}{l}-5.79 * * * \\
(1.01)\end{array}$ \\
\hline $\begin{array}{l}\text { Log Alpha } \\
\text { Constant }\end{array}$ & $\begin{array}{l}-0.63 * * * \\
(0.04)\end{array}$ & $\begin{array}{l}-0.64 * * * \\
(0.04)\end{array}$ & $\begin{array}{l}-0.64 * * * \\
(0.04)\end{array}$ & $\begin{array}{l}-0.65 * * * \\
(0.04)\end{array}$ \\
\hline $\mathrm{N}$ & 2362 & 2362 & 2362 & 2362 \\
\hline Pseudo R-squared & 0.01 & 0.01 & 0.02 & 0.02 \\
\hline
\end{tabular}

Note: Variance exceeds the mean indicating negative binomial regression is appropriate. Standard errors in parentheses. ${ }^{*} \mathrm{p}<0.05,{ }^{* *} \mathrm{p}<0.01,{ }^{* * *} \mathrm{p}<0.001$. 